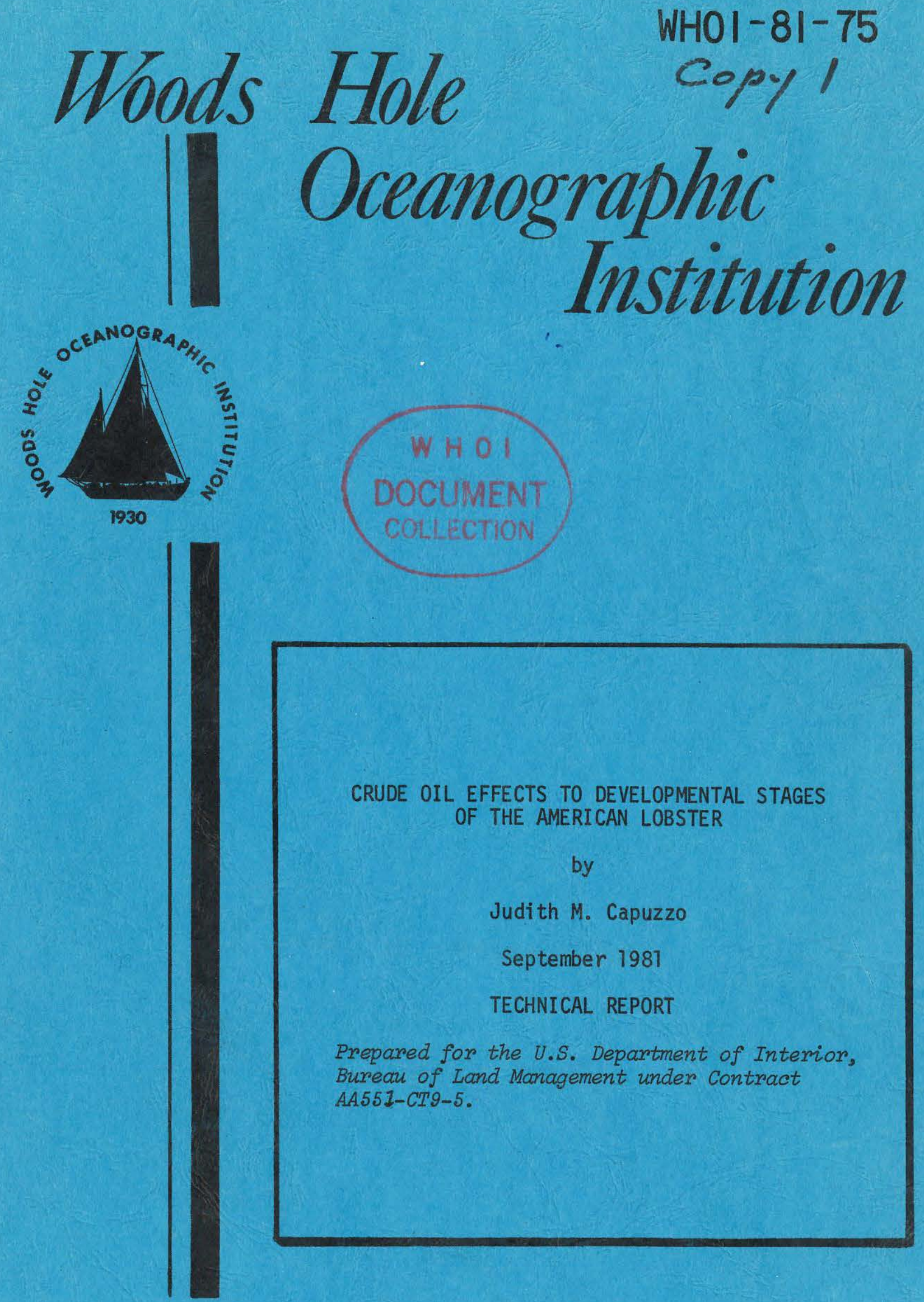

WOODS HOLE, MASSACHUSETTS 02543 
WHOI $-81-75$

\section{CRUDE OIL EFFECTS TO DEVELOPMENTAL STAGES OF THE AMERICAN LOBSTER}

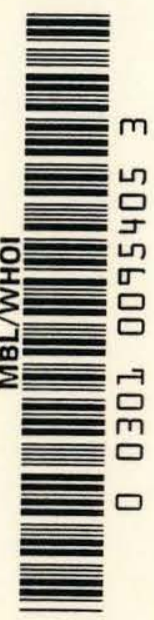

Judith M. Capuzzo

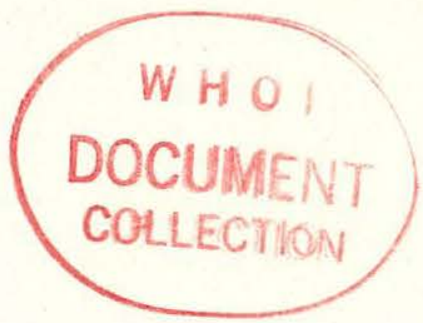

WOODS HOLE OCEANOGRAPHIC INSTITUTION

Woods Hole, Massachusetts 02543

September 1981

TECHNICAL REPORT

Prepared for the U.S. Department of Interior, Bureau of Land Management under Contract AA551-CT9-5.

Reproduction in whole or in part is permitted for any purpose of the United States Govermment. This report should be cited as: Woods Hole Oceanog. Inst. Tech. Rept. WHOI-81-75.

Approved for Distribution:

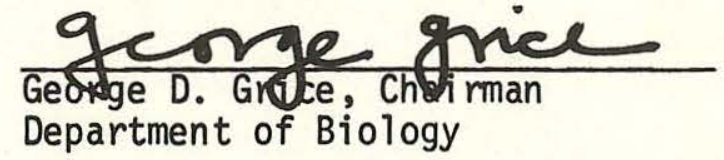


This report has been reviewed by the Bureau of Land Management and approved for publication. Approval does not signify that the contents necessarily reflect the views and policies of the Bureau, or does mention of trade names or commercial products constitute endorsement or recommendation for use. 
Table of Contents

Page

I. Abstract.............................................

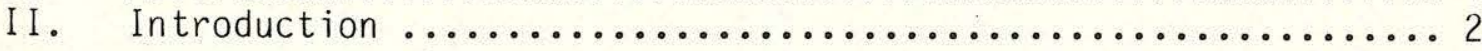

I I Methods

1. Culture of larval and juvenile lobsters ............ 4

2. Bioassay systems $\ldots \ldots \ldots \ldots \ldots \ldots \ldots \ldots \ldots \ldots \ldots \ldots \ldots \ldots \ldots \ldots \ldots, 4$

a. Larval lobsters ............................ 4

b. Juvenile lobsters .......................... 6

c. Contamination of Artemia nauplii .............. 7

3. Physiological techniques $\ldots \ldots \ldots \ldots \ldots \ldots \ldots \ldots \ldots \ldots, 8$

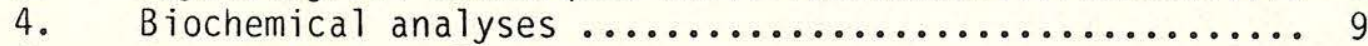

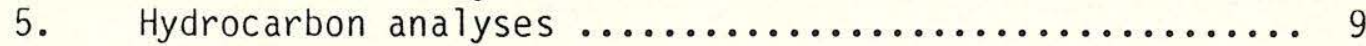

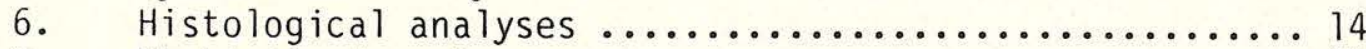

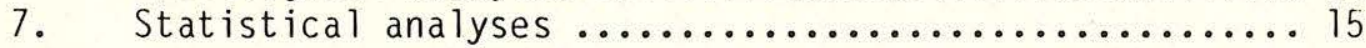

IV Results

1. Survival of larval lobsters ..................... 15

2. Effects of oil-seawater exposure on larval lobsters ... 15

3. Effects of chronic exposure to oil contaminated

4. seawater or sediments on juvenile lobsters ........... 25

4. Effects of ingestion of oil contaminated Artemia nauplii on larval and postlarval lobsters $\ldots \ldots \ldots . . .43$

5. Body burden evaluations $\ldots \ldots \ldots \ldots \ldots \ldots \ldots \ldots \ldots \ldots \ldots \ldots \ldots$

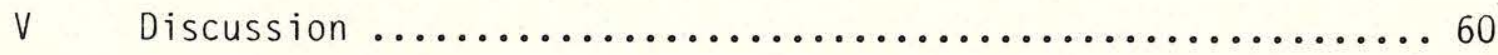

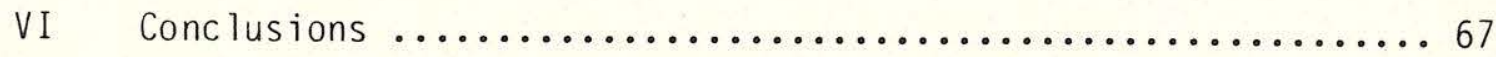

VII Acknowledgements $\ldots \ldots \ldots \ldots \ldots \ldots \ldots \ldots \ldots \ldots \ldots \ldots \ldots$

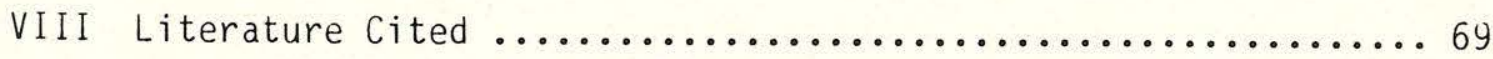

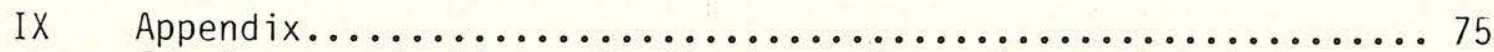

Final summarization - Westinghouse 0cean Research Laboratory 
Abstract:

The effects of South Louisiana crude oil on larvae and juveniles of the American lobster Homarus americanus were investigated in continuous flow bioassay systems. Response parameters measured included estimates of the effects of oil exposure on survival, energetics, biochemical composition, hydrocarbon accumulation and histological aberrations. Disruptions in the energetics of larval development were observed with exposure to oil-seawater mixtures and with ingestion of oil-contaminated Artemia nauplii; the changes in energetics were correlated with a shift in the normal patterns of lipid utilization and storage in larval lobsters. Hydrocarbon turnover appeared to be rapid and little accumulation, except of the higher molecular weight constituents, was observed. Recovery of larval and early postlarval stages was not immediate upon transfer to uncontaminated seawater but the normal pattern of energy storage and utilization was slowly restored.

Postlarval lobsters were less sensitive to crude oil-seawater mixtures than the larval stages and no disruption in energetics was observed. Reductions in respiratory activity and bioaccumulation of both aliphatic and aromatic compounds, however, were observed in postlarval lobsters exposed to oil-contaminated sediments. Postlarval lobsters appeared to have longer retention times and slower turnover rates of petroleum hydrocarbons than the larval stages and persistence of petroleum hydrocarbons in sediments might present a chronic contamination problem to benthic stages of the American lobster. 
Introduction:

Interest in oil and gas exploration in the coastal regions of the northwestern Atlantic has increased in recent years in efforts to find petroleum resources. Increased exploitation, however, poses many unanswered questions concerning potential toxic effects of oil from drilling and transport operations on commercially important species and the resulting economic impact on established fisheries.

The American lobster (Homarus americanus) is found off the northeastern coast of the United States and off Atlantic Canada and is of particular ecological and economic importance. The life cycle of the lobster includes both planktonic and benthic stages (Herrick, 1896, 1911) and, thus, the lobster may be exposed to a wide range of stress conditions as a result of oil contamination in the sea. The lobster has four larval stages, the larval period extending from the time of hatching from the egg to the fifth molt or attainment of the first postlarval or juvenile stage (stage V). Stage IV larvae have fully developed claws and are active swimmers but may continue to be found among the plankton for several days before seeking a suitable benthic habitat (Cobb, 1976; Hughes and Matthiessen, 1962). Lobster populations in southern New England spawn during the early summer and the planktonic stages are abundant in surface waters from May through August at seawater temperatures of $15^{\circ}-22^{\circ} \mathrm{C}$. Short-term exposure of planktonic larval stages of oil dispersed in surface waters could result in reduced survival of larval lobsters, increased susceptibility to other environmental stresses and changes in the rates of growth and development. Wells and Sprague (1976) found stage I lobster 
larvae to be more sensitive to Venezuelan crude oil than later larval stages and observed changes in development time to the first post-larval stage, the occurrence of intermediate larvae and reductions in food consumption as a result of oil exposure. Forns (1977) reported a threshold sensitivity between 0.1 and $1.0 \mathrm{ppm}$ South Louisiana crude $0 i 1$ for planktonic larval lobsters with reduced feeding and swimming activity and prolonged development time being observed at the higher exposure concentration.

An understanding of the effects of crude oil on development, growth and energetics of larval and juvenile lobsters is needed to assess the impact of this marine pollutant on lobster populations and the lobster fishery. The objectives of our research program have been to identify the effects of crude oil exposure on various developmental stages of the lobster. The specific tasks of the research were as follows: (1) to assess the physiological effects of sublethal exposure to South Louisiana crude oil on all larval stages of the American lobster; (2) to assess the physiological effects of ingestion of an $0 i 1$ contaminated food source on all larval stages; (3) to assess the physiological effects of chronic exposure to oil contaminated seawater and sediments on juvenile lobsters; (4) to evaluate body burden and depuration of larval and juvenile lobsters exposed to oil in the above experiments; and (5) to evaluate histological aberrations of larval and juvenile lobsters exposed to $0 i 1$ in the above experiments. 
Methods:

Culture of larval and juvenile lobsters

Female egg-bearing lobsters were obtained from local fishermen and maintained in flowing seawater (30-31 \%/00 salinity) at ambient temperatures on a diet of mussels and squid. The eggs developed normally and began to hatch when seawater temperatures reached $18-20^{\circ} \mathrm{C}$. After hatching, stage I larvae were transferred to fiberglass plankton-kreisels, described by Hughes et al. (1974), and maintained in flowing seawater at $20-22^{\circ} \mathrm{C}$ on a diet of live or frozen brine shrimp (Artemia sp.). Stage IV lobsters were transferred to compartmented polypropylene trays and maintained in flowing seawater under the same temperature and feeding regime.

Bioassay systems

a. Larval lobsters

Two bioassay systems were designed for the study of larval stages. A modification of the continuous flow system described by Forns (1976) was used to determine the survival of lobsters exposed to $0.25 \mathrm{ppm}$ South Louisiana crude oil for comparison with previous work on the acute effects of South Louisiana crude $0 i 1$ on larval lobsters. This system consisted of four 40-liter fiberglass plankton-kreisels (Hughes et al., 1974) with a seawater flow of $325 \mathrm{ml} / \mathrm{minute}$; 0 il was added to the system using a Harvard peristaltic pump to allow a final concentration of $0.25 \mathrm{ppm}$ whole crude oil. Lobsters were stocked at a density of 500 stage I larvae per kreisel and stage of development and mortality were checked daily. Larvae were exposed to oil for the duration of larval development and percent 
survival and time to the postlarval form were compared with control animals; the survival of control and exposed animals maintained in this bioassay system were also compared to those maintained in the second bioassay system described below.

The second bioassay system was a continuous flow system consisting of $24500 \mathrm{ml}$ fleakers $(R)$ (Corning Glass) as the assay chambers. Each assay chamber was modified by the addition of an intake tube and an outflow port at the $400 \mathrm{ml}$ mark covered with Nitex $(R)$ screening to allow continuous flow (Capuzzo et al., 1976). Seawater crude oil mixtures were supplied to the assay chambers by peristaltic pumping at a flow rate of $3.35 \mathrm{ml} / \mathrm{min}$ and temperature and flow rates were maintained at constant levels. Seawater or seawater-crude oil mixtures were delivered from 13-liter glass carboys. For preparation of seawater-crude oil mixtures used in bioassays, oil-seawater dispersions (250 ppm) were mixed by gentle stirring for $24 \mathrm{~h}$ at $10^{\circ} \mathrm{C}$ (Anderson et al., 1974a) prior to addition to the 13-1iter carboys. Aliquots of the $250 \mathrm{ppm}$ oil-seawater dispersion were withdrawn by pipet from below the surface of the stock solution and added to the carboys directly and diluted at the designated concentration. Carboys were replaced every $6 \mathrm{~h}$ and the turnover time in each assay chamber was $1 \mathrm{~h}$. Hydrocarbon concentrations of oil-seawater dispersions supplying the assay chambers were assayed by gas chromatography for each experiment.

For each larval stage, 5 larvae were added to an assay unit maintained on a diet of live Artemia nauplii to reduce cannibalism and exposed to 0.25 ppm South Louisiana crude oil. Larvae were monitored for survival, 
respiration rates, ammonia excretion rates and 0:N ratios at selected times ( $24 \mathrm{~h}$ and $72 \mathrm{~h}$ ) during a 96 hour exposure period at $20^{\circ} \mathrm{C}$ and compared with control animals maintained under identical conditions. At the end of the 96 hour exposure period animals were subsampled for hydrocarbon and histological analyses.

To evaluate the effect of crude oil exposure on the molt to the postlarval form, stage IV larvae were exposed to $0.25 \mathrm{ppm}$ South Louisiana crude $0 i 1$ for $96 \mathrm{~h}$ and respiration rates, ammonia excretion rates and $0: \mathrm{N}$ ratios were monitored daily. After the $96 \mathrm{~h}$ exposure period (Day 4), lobsters were transferred to clean seawater and maintained for 1 week to assess success of molting to the postlarval form, physiological changes associated with molting and degree of recovery from oil exposure. During the post-exposure period the various physiological parameters described above were measured at $96 \mathrm{~h}$ (Day 8) and $168 \mathrm{~h}$ (Day 11). At the end of the 1 week post-exposure period, animals were assayed for biochemical composition.

b. Juvenile lobsters

To test the chronic effects of oil exposure on postlarval lobsters, stage VII lobsters were exposed to $0.25 \mathrm{ppm}$ crude 011 for 78 days; during the exposure period test lobsters were monitored for respiration rates, ammonia excretion rates, 0:N ratios, weight increases, molting activity, feeding rates and survival. $0 i 1$ exposed lobsters were compared to control lobsters maintained in the same bioassay system described above. At the end of the experiment both control and oil-exposed lobsters were sacrificed for histological examination and for measurement of hydrocarbon accumulation. 
To test the long-term effects of exposure to oil-contaminated sediments on postlarval lobsters, stage $X$ lobsters were exposed to an oil contaminated sandy substrate and were monitored for changes in standard respiration rates during this chronic exposure. Six rectangular fibreglassed plywood boxes were constructed as the experimental chambers; the dimensions of each box were $120 \mathrm{~cm}$ long $\times 10 \mathrm{~cm}$ wide $\times 12.5 \mathrm{~cm}$ deep and each box was sectioned into 11 cubicles. Seawater input was unidirectional and each cubicle was separated by PVC screening. Coarse-fine grained, autoclaved beach sand was placed to a depth of $1.25 \mathrm{~cm}$ in the bottom of each of the six boxes and the boxes were filled with 2 liters of filtered (50 $\mu \mathrm{m}$ ) seawater, covering the sediments with a water depth of $1.25 \mathrm{~cm}$. To each of the three exposure tanks, $6 \mu$ l of SLCO were added via syringe to the middle of the box and allowed to spread over the surface. 0il-contaminated sediments were incubated for 1 week before seawater flow was started and test organisms were added to the experimental tanks. Control sediments were treated in a similar manner without the addition of crude 0i1. Samples of sediments and test organisms were taken at weekly intervals for hydrocarbon and histological analyses.

c. Contamination of Artemia nauplii

Brazilian Strain Artemia cysts were obtained from Aquafauna Inc. The Artemia hatching system consisted of a series of $500 \mathrm{ml}$ glass separatory funnels, fitted with glass rods for gentle aeration. Artemia cysts were hatched in concentrations of South Louisiana crude oil ranging from 0.125 to $1.000 \mathrm{ppm}$ and percent hatching survival and nauplii viability were compared with control organisms hatched in uncontaminated seawater (30-31 
$\%$, $\left.20^{\circ} \mathrm{C}\right)$. Prior to addition to separatory funnels, oil-seawater dispersions (250 ppm) were mixed by gentle stirring for $24 \mathrm{~h}$ at $10^{\circ} \mathrm{C}$. Aliquots of seawater-crude oil mixtures were withdrawn by pipet from below the surface of the stock solution and added to the separatory funnels directly and diluted to the designated concentration; $500 \mathrm{mg}$ of Artemia cysts were added to each separatory funnel and mixed by gentle aeration. Time to hatching, hatching survival and nauplii viability were recorded for each culture.

Each larval stage was fed Artemia nauplii which had been previously exposed to $0.25 \mathrm{ppm}$ South Louisiana crude 011 ; bioassays were conducted for $96 \mathrm{~h}$ at $20^{\circ} \mathrm{C}$ in the same continuous flow bioassay system described above. Artemia nauplii were hatched daily and used in feeding experiments within 24-36 h. Five lobster larvae were added to each $500 \mathrm{ml}$ assay chamber and 500 Artemia nauplii were added daily. Respiration rates, ammonia excretion rates and 0:N ratios were monitored at $24 \mathrm{~h}$ and $72 \mathrm{~h}$ during the exposure period and compared with control organisms maintained under identical conditions. During the exposure period comparisons were also made on survival and molting frequency of control and exposed animals. At the end of the $96 \mathrm{~h}$ period, larvae were collected and frozen for GC analysis.

Physiological techniques

Respiration rates of individual larvae were measured using both microrespirometers and a Gilson differential respirometer according to the techniques described by Capuzzo and Lancaster (1979). Equilibrium between the gas and liquid phase of $\mathrm{O}_{2}$ diffusion in the respirometer flasks 
were enhanced by gently shaking the respirometer flasks. At the end of each set of oxygen uptake mesurements, the seawater in the respirometer flasks was analyzed for $\mathrm{NH}_{4}^{+}-\mathrm{N}$ by the method of Solorzano (1969) in order that an in situ estimate of ammonia excretion rates and the $0: \mathrm{N}$ ratio (atomic ratio of oxygen consumed to $\mathrm{NH}_{4}^{+}-\mathrm{N}$ excreted) could be made; ammonia levels were compared with control blanks. Biochemical analyses

At the end of the exposure periods, animals were weighed, dried at $70^{\circ} \mathrm{C}$ for $24 \mathrm{~h}$ and reweighed, and assayed for biochemical composition. The relative percentages of protein, lipid, carbohydrate, chitin and ash were determined for each stage of oil-exposed and control lobsters. Protein, carbohydrate, chitin and ash were determined by the methods described by Raymont et al. (1964) using dry tissues; lipid content was analyzed by the method of Marsh and Weinstein (1966). Hydrocarbon analyses

Seawater samples were initially analyzed for hydrocarbon content using the UV-technique described by Neff and Anderson (1975); although this technique does not detect the full range of hydrocarbons present in South Louisiana crude oil, it was useful as a preliminary index of the consistency of the concentrations of naphthalene and alkylnaphthalenes from day to day. The full range of hydrocarbons were detected by gas chromatography after sample extraction. Samples were extracted with hexanes and concentrated using a Bucchi rotary evaporator; gas chromatograms were compared with a sample of South Louisiana crude oil (Figures 1 and 2). A comparison of the two chromatograms indicates that the whole oil fraction 
rather than just the water soluble components is present in the seawatercrude oil mixture. As microdroplets of oil may be ingested by planktonic organisms, this would appear to be a more realistic presentation of oil to the bioassay organisms than presenting only the water soluble fraction. There is some enhancement relative to the composition of crude oil at possibly the naphthalene peak and at the $\mathrm{C}_{13}$ peak; identification of the naphthalene peak is based on comparing its retention time against a standard. The concentration of total hydrocarbons during the bioassay experiments was $0.25 \pm 0.05 \mathrm{ppm}$ (mean of 6 determinations \pm 1 S. D.). For sediment analysis, approximately $5 \mathrm{~g}$ of sand were sieved to remove all particles $0.25 \mathrm{~mm}$, extracted with $\mathrm{n}$-hexane and analyzed by GC according to the procedures described by Farrington (1976). Samples were taken on day 1 , day 15 and day 31.

Hydrocarbon content of larval and juvenile lobsters were determined using two techniques: 1) extraction procedure, followed by analysis using GC glass capillary techniques; and (2) direct analysis by gas chromatography thermal distillation pyrolysis (GCTDP). Details of both procedures are given below. 


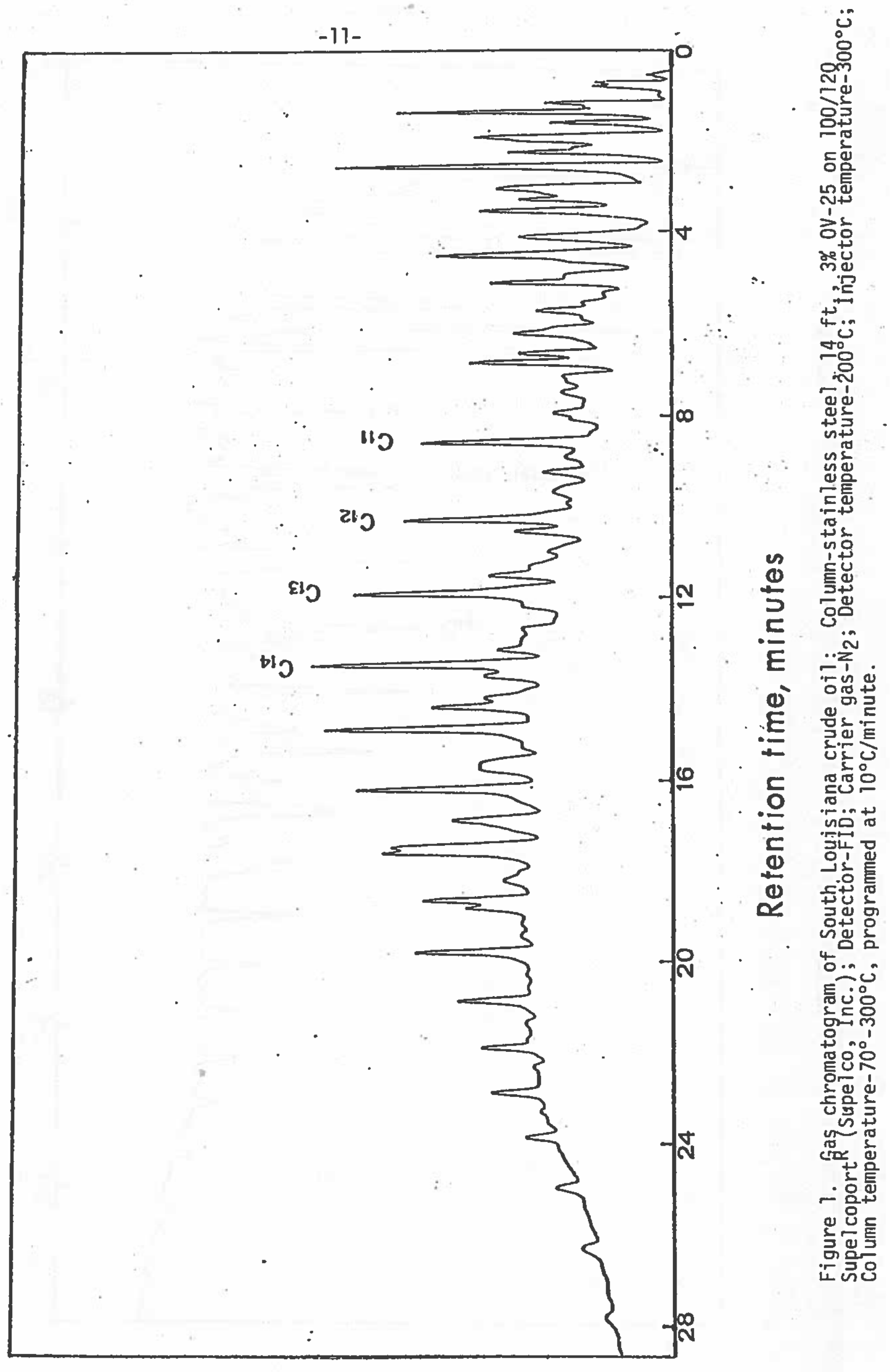




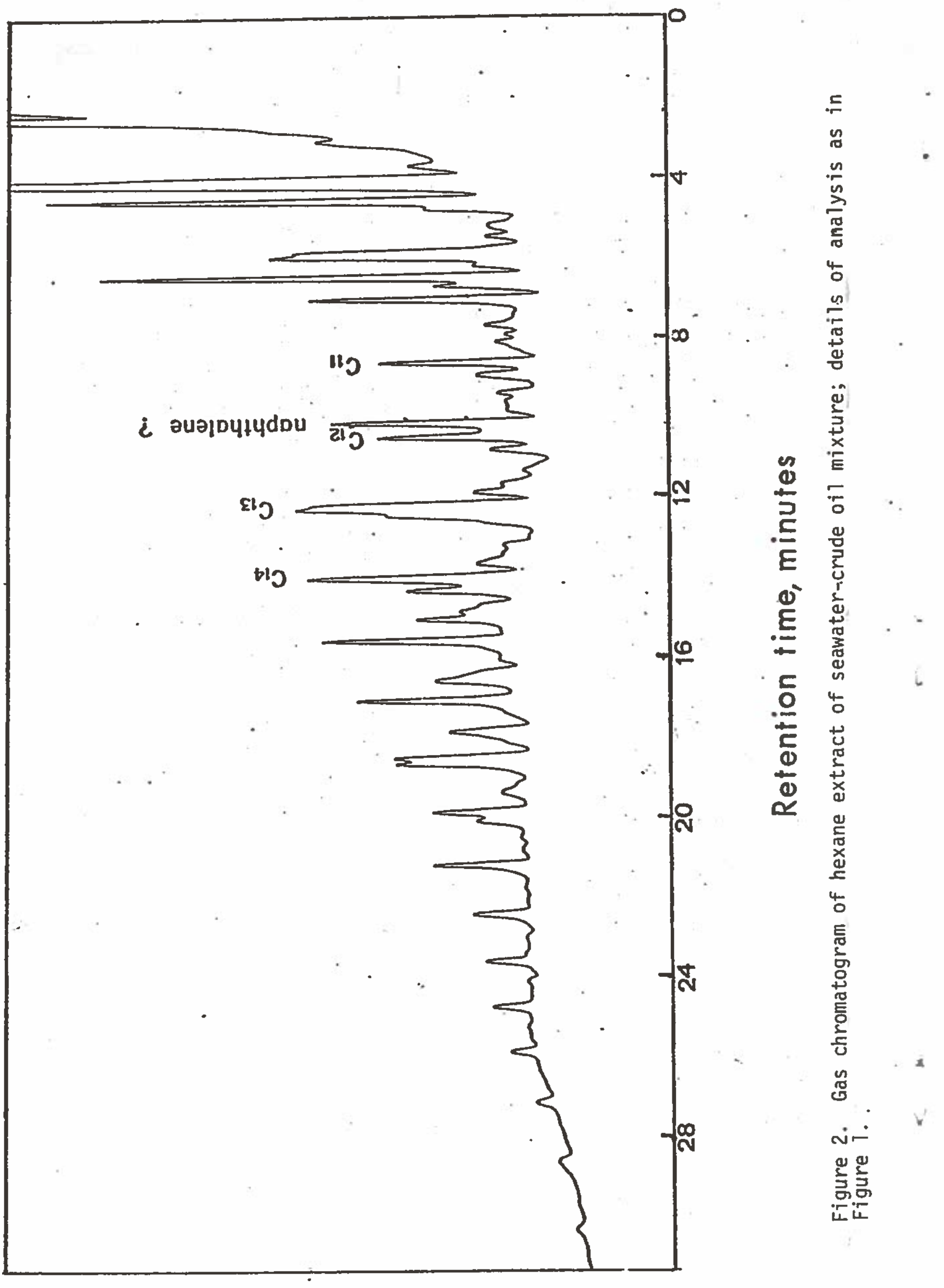


(1) Extraction procedure - Lobsters were prepared for hydrocarbon analyses according to the procedures described by Farrington and Davis (1978). Whole organisms were freeze dried and dry weights determined; after drying lobsters were placed in $10 \mathrm{ml}$ vials with Teflon-lined screw caps and $2.5 \mathrm{~m} 1 \mathrm{n}$-hexane to prepare the samples for column chromatography. Clean-up columns (11 mm i.d. x $50 \mathrm{~cm}$ long with $250 \mathrm{ml}$ reservoir) were packed with deactivated silica ge] (100-200 $\mu \mathrm{m}$ mesh) and alumina ( 200 mm mesh). The extract was added to a column, washed with hexane and collected as fraction 1; the column was then rinsed with 10\% toluene-90\% hexane and then $20 \%$ toluene- $80 \%$ hexane and this was collected as fraction 2; finally the column was rinsed with toluene and this was collected as fraction 3 . The column extracts were then concentrated using a Bucchi rotary evaporator and analysed by glass capillary GC (Hewlett-Packard Model 5830). Extraction techniques followed by glass capillary GC analyses are effective in the determination of $\mathrm{C}_{14}-\mathrm{C}_{33}$ hydrocarbons.

(2) Gas Chromatography Thermal Distillation Pyrolysis (GCTDP) - In a recently funded NOAA, Sea Grant project, Dr. Jean K. Whelan has applied the technique of gas chromatography-thermal distillationpyrolysis to determine organic chemical composition of marine sediments and biota. The procedure combines the techniques of GC-thermal distillation (designed to recover volatile, absorbed organic molecules without significant alteration) and GC-pyrolysis (designed to crack the molecules and use the molecular patterns of cracked products for identification). Such techniques 
require a small sample size (0.1-300 mg) and are more rapid and less expensive than extraction procedures. A sample is heated from $100^{\circ} \mathrm{C}$ to $800^{\circ} \mathrm{C}$ at a rate of $40^{\circ} \mathrm{C} / \mathrm{min}$ in a helium stream and total hydrocarbons evolved are measured as a function of temperature. Two peaks are measured, the first $\left(P_{1}\right)$ represents free absorbed hydrocarbons and the second $\left(P_{2}\right)$ cracking products obtained by pyrolysis. The components of each peak may be analyzed in more detail by capillary GC or GC Mass Spectroscopy (GC-MS). The technique is limited to hydrocarbon determination with the range of $C_{1}-C_{30}$.

Histological analyses

Whole lobsters were fixed in Bouin's fixative after the carapace was separated at the end of the thorax. After embedding in paraplast $(R)$ and sectioned at $10 \mu \mathrm{m}$ with an American 0ptical Microtome, gill tissue from larval and juvenile lobsters from each of the experiments were stained with hematoxylin and counterstained with eosin; aberrations in gill tissue were compared beteen control and oil-exposed lobsters.

More detailed histological analyses were carried out with control and oil-exposed animals from the juvenile lobster experiments. Histological preparations of gill, hepatopancreas and muscle were sectioned at $6 \mu \mathrm{m}$ and two staining techniques were implemented: (1) hematoxylin-eosin and (2) Alcian blue-nuclear fast red; the latter staining technique enhances the staining of degenerate cells (Johnson, 1980). 
Statistical analyses

Differences among physiological parameters measured and biochemical composition of the oil-exposed and control lobsters were assessed by analysis of variance; difference in growth and physiological parameters of juvenile lobsters were assessed by analysis of covariance (Sokal and Rohlf, 1969).

Results:

Survival of larval lobsters

There was no significant difference in survival or time to the first postlarval molt between control lobsters maintained in the two bioassay systems; similar results were also obtained with ojl-exposed lobsters (Table 1). At $20^{\circ} \mathrm{C} 33.3 \%$ survival of oil exposed lobsters was observed, compared to $40 \%$ survival for control lobsters; much of the mortality was due to cannibalism between the test organisms. In the study by Forns (1976-78), survival of control and oil-exposed lobsters ranged from $20.5 \%$ to $28.9 \%$ over the range of oil concentrations from 0.0 to $1.5 \mathrm{ppm}$. The time to complete larval development was 17.5 days for both control and exposed lobsters in the present study. Effects of oil-seawater exposure on larval lobsters

Survival of larval lobsters exposed to $0.25 \mathrm{ppm}$ South Louisiana crude $0 i 1$ for $96 \mathrm{~h}$ at $20^{\circ} \mathrm{C}$ is presented in Table 2. There was no significant difference in survival of lobsters from the control and oil-exposed groups for each larval stage. Stage IV larvae, however, had significantly higher $(P<0.01)$ survival rates in both groups than the other three larval stages; the mortality of stages I, II and III larvae is largely attributed to cannibalism. 
Table 1. Survival of larval lobsters exposed to $0.25 \mathrm{ppm}$ South Louisiana crude oil in two bioassay systems for the duration of larval development

\begin{tabular}{|c|c|c|c|c|}
\hline & \multicolumn{2}{|c|}{ Control } & \multicolumn{2}{|c|}{ 0il-Exposed } \\
\hline & System 1 & System 2 & System & System 2 \\
\hline Percent survival & $\begin{array}{l}40.0 \mathrm{a} \\
(2.5)\end{array}$ & $\begin{array}{l}39.2 \mathrm{~b} \\
(1.8)\end{array}$ & $\begin{array}{l}33.3 \mathrm{a} \\
(2.0)\end{array}$ & $\begin{array}{l}32.8 \mathrm{~b} \\
(1.5)\end{array}$ \\
\hline Time to postlarval molt & $\begin{array}{l}17.5^{a} \\
10.5\end{array}$ & $\begin{array}{l}17.5^{b} \\
(0.5)\end{array}$ & $\begin{array}{l}17.5^{a} \\
(1.5)\end{array}$ & $\begin{array}{l}17.5^{b} \\
(1.0)\end{array}$ \\
\hline
\end{tabular}

a Mean of 4 replicate assays $( \pm 1$ S.E.).

b Mean of 12 replicate assays ( \pm 1 S.E.). 
Respiration rates measured at $24 \mathrm{~h}$ and $72 \mathrm{~h}$ during the exposure period were not significantly different from one another for each larval stage in the control group (Figure 3 ). The weight-specific respiration rates incresed with each successive larval stage as previously reported by Capuzzo and Lancaster (1979); these measurements reflect the level of metabolism during feeding for each larval stage.

Significant reductions in respiration rates of oil-exposed stage I larvae were observed at $24 \mathrm{~h}$ and $72 \mathrm{~h}$. There was no significant difference in respiration rates at $24 \mathrm{~h}$ for any of the later larval stages between control and oil-exposed groups; however, significant reductions $(P<0.01)$ in respiration rates of $0 i 1$-exposed stage II, III and IV lobsters were observed at $72 \mathrm{~h}$ (Table 3 ).

Ammonia excretion rates of larval lobsters measured at $24 \mathrm{~h}$ and $72 \mathrm{~h}$ during the exposure period are presented in Figure 3. There was no significant difference between the two sets of measurements for any of the larval stages in the control group or for stage I and IV lobsters in the oil-exposed group. 0il-exposed stage II and III lobsters had significantly higher $(P \triangleleft 0.01) \mathrm{NH}_{4}^{+}-\mathrm{N}$ excretion rates at $72 \mathrm{~h}$ (Table 4 ).

The $0: N$ ratios of control and 011 -exposed lobsters are presented in Figure 3. For control lobsters the $0: \mathrm{N}$ ratios ranged from 20.6 to 27.3 and are within the range previously reported for larval lobsters (Capuzzo and Lancaster, 1979). The 0:N ratio of oil-exposed lobsters at $24 \mathrm{~h}$ ranged from 17.0 to 22.4; however, a greater reduction in $0: \mathrm{N}$ ratio was observed at $72 \mathrm{~h}(\mathrm{r}$ ange $=9.7-14.9)$. 
Table 2. Survival of larval lobsters exposed to $0.25 \mathrm{ppm}$ South Louisiana crude $0 i 1$ for $96 \mathrm{~h}$ at $20^{\circ} \mathrm{C}$

\begin{tabular}{ccc}
\hline Stage & Control $(\%)^{a}$ & 0i1-exposed $(\%)^{a}$ \\
& & \\
\hline I & 43.2 & 48.9 \\
& $(1.2)$ & $(1.5)$ \\
II & 41.3 & 46.6 \\
& $(1.5)$ & $(1.3)$ \\
II I & & 51.1 \\
& 50.0 & $(1.6)$ \\
& $(1.8)$ & 96.0 \\
IV & 92.7 & $(1.5)$ \\
& $(1.5)$ & \\
\hline
\end{tabular}

a Mean value of 12 replicate assays ( \pm 1 S.E.). 


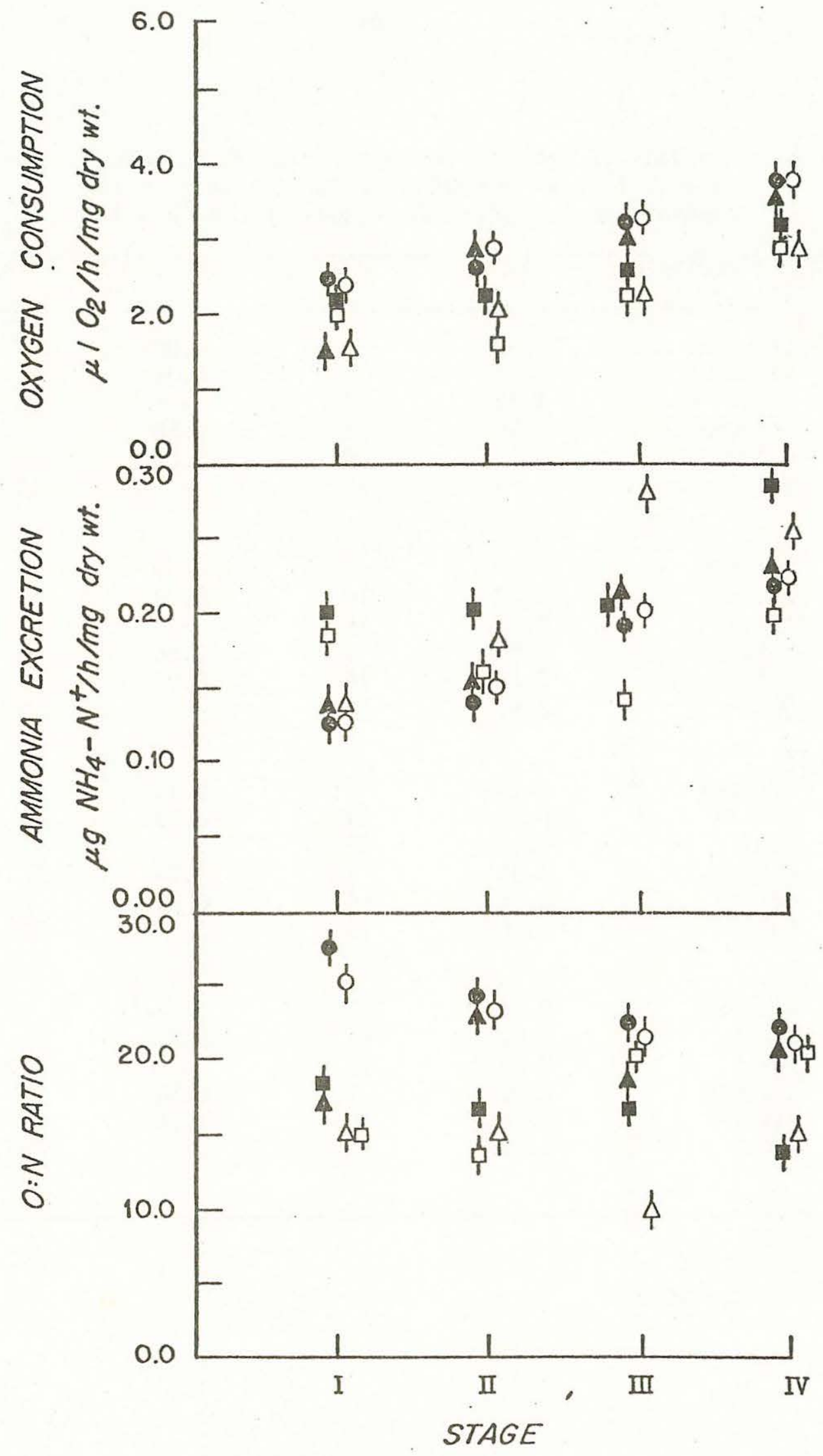

Figure 3. Respiration rates, ammonia excretion rates and $0: \mathrm{N}$ ratios of larval lobsters exposed to $0.25 \mathrm{ppm}$ South Louisiana crude oil through seawater exposure (triangles) and ingestion of contaminated Artemia nauplii (squares) for $96 \mathrm{~h}$ at $20^{\circ} \mathrm{C}$; control values-circles; closed symbols$24 \mathrm{~h}$; open symbols $-72 \mathrm{~h}$; mean of $8+1 \mathrm{~S}$. E. 
Table 3. Analysis of variance of respiration rates measured for each larval stage of the American lobster at $24 \mathrm{~h}$ and $72 \mathrm{~h}$ during exposure to $0.25 \mathrm{ppm}$ South Louisiana crude oil

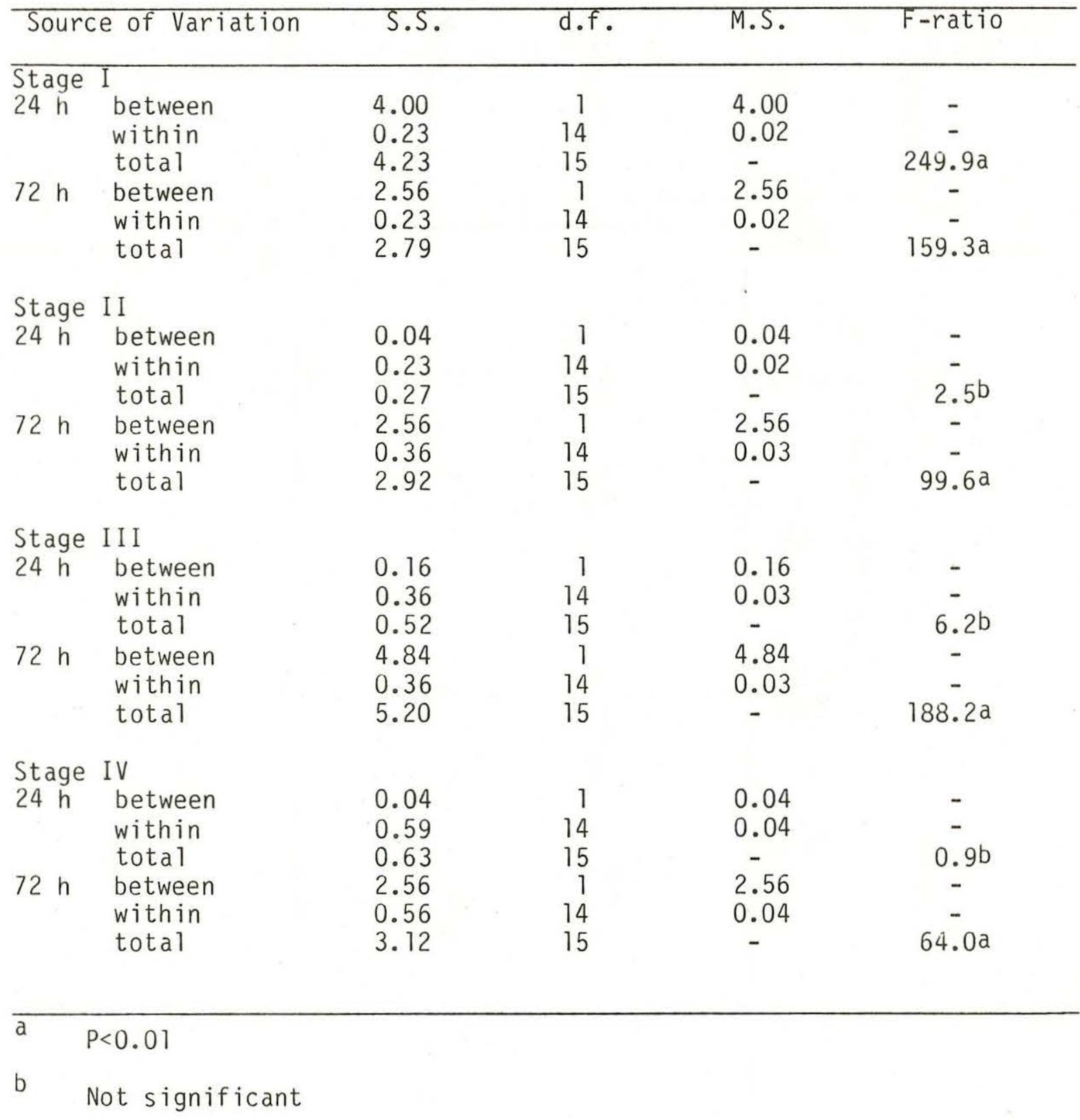


Table 4. Analysis of variance of ammonia excretion rates for each larval stage of the American lobster at $24 \mathrm{~h}$ and $72 \mathrm{~h}$ during exposure to $0.25 \mathrm{ppm}$ South Louisiana crude oil

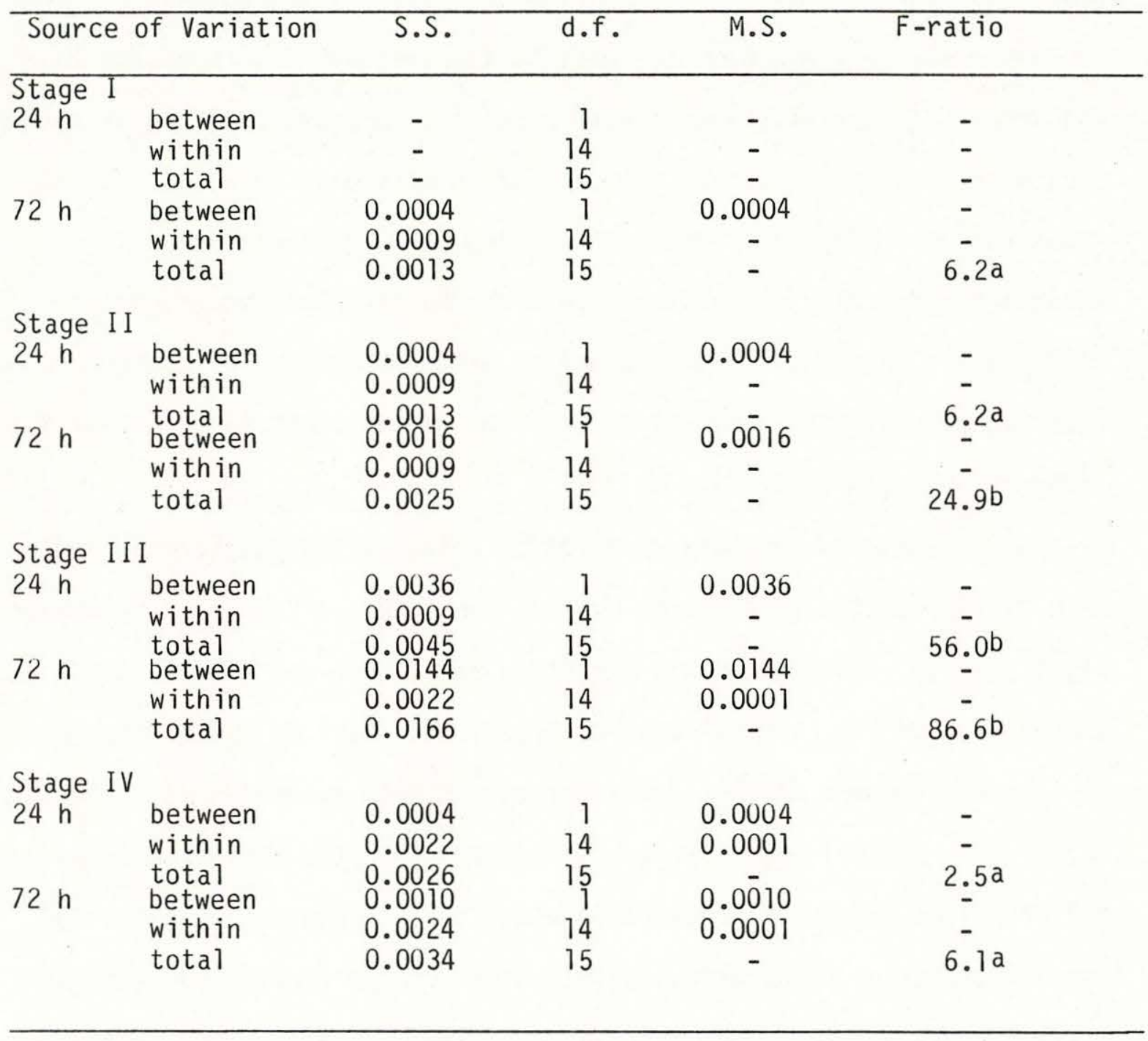

a Not significant

b $\quad P<0.01$ 
In previous work in our laboratory we found that the weight-specific respiration and ammonia excretion rates of lobsters are highest in stage IV larvae and decrease with the molt to the postlarval form (stage V). The results in the experiments with stage IV and V lobsters are in agreement with those findings but the decline in metabolic rates for control lobsters takes place just prior to molting to stage V (Figure 4). All animals successfully molted to stage $V$ and molting was synchronous for a 11 lobsters on day 5. Metabolic rates were consistent for control lobsters during the post-exposure period; the $0: \mathrm{N}$ ratio of stage IV and $\mathrm{V}$ lobsters averaged 24.5 .

For oil-exposed lobsters respiration rates were significantly lower $(R<0.01)$ during the first three days of exposure and the $0: \mathrm{N}$ rations were significantly reduced; ammonia excretion rates were not significantly different from the rates of control organisms except on day 1 (Figure 4). At day 4 there was a slight increase in both metabolic parameters relative to control organisms but a reduced $0: \mathrm{N}$ ratio was determined. All organisms successully molted to stage $V$, but respiration rates and ammonia excretion rates were significantly reduced $(R<0.01)$ during the post-exposure period (Table 5). The $0: \mathrm{N}$ ratio of oil-exposed lobsters during the exposure period averaged 16.8 and during the post-exposure period averaged 25.5 .

The dry weight and biochemical composition of all larval and postlarval stages from the control and oil-exposed groups are presented in Table 6. There was no significant difference in dry weight of any lobster 


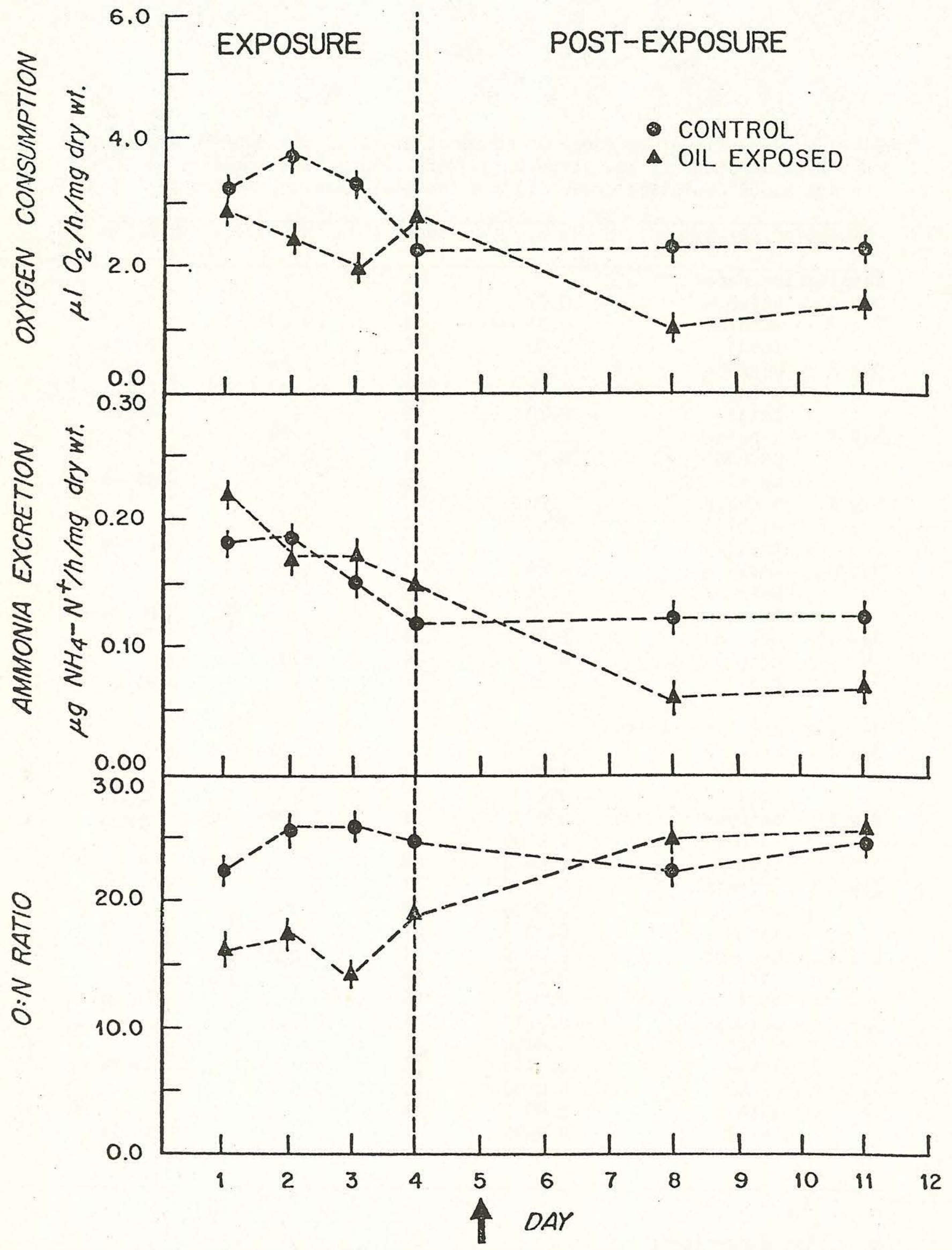

Figure 4. Respiration rates, ammonia excretion rates and $0: \mathrm{N}$ ratios of stage IV and $V$ lobsters exposed to $0.25 \mathrm{ppm}$ South Louisiana crude 011 for $96 \mathrm{~h}$ at $20^{\circ} \mathrm{C}$ and maintained for 1 week following exposure in clean seawater; arrow indicates molt to stage $V$; mean of $8 \pm 1 \mathrm{~S}$. E. 
Table 5. Analysis of variance of respiration rates and ammonia excretion rates of stage IV and stage $V$ lobsters during $96 \mathrm{~h}$ exposure to 0.25 ppm South Louisiana crude oil and the post-exposure period

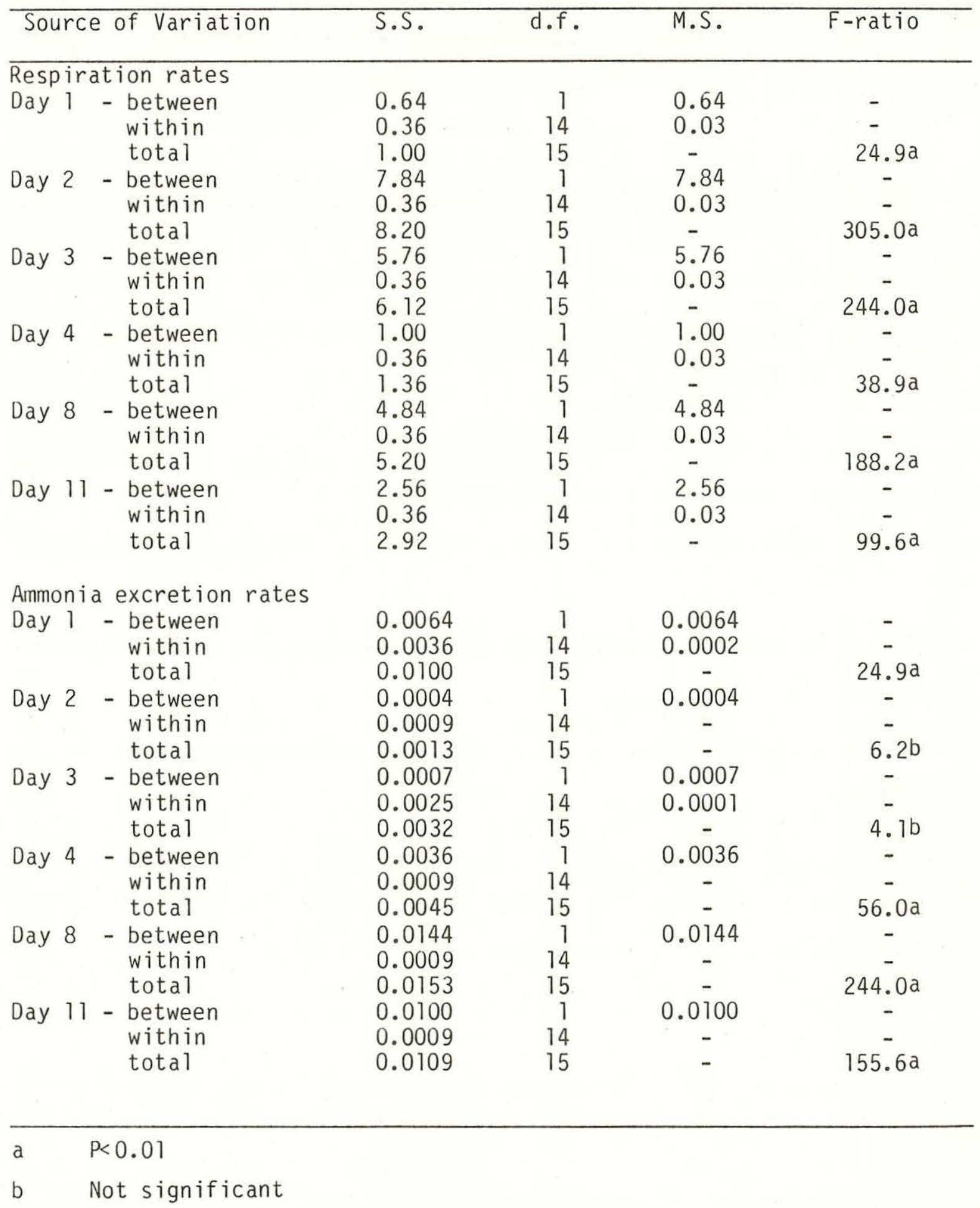


stage between control and oil-exposed groups. Protein was the major biochemical constituent in all larval stages and the first postlarval stage of both control and oil-exposed groups. For control lobsters there were significant decreases ( $R$ 0.01) in both carbohydrate and lipid content and significant increases in ash and chitin content in the later larval and postlarval stages (stages III, IV and V). Similar trends were observed among oil-exposed lobsters, but there were significant differeces in protein and lipid content and the protein:lipid ratio for each larval stage between control and oil-exposed groups; among oil-exposed lobsters there were significantly higher $(R<0.01)$ protein contents and significantly lower lipid contents of all larval stages. Stage V lobsters, sampled at the end of the post-exposure period, had a slightly higher protein content but no significant difference in lipid content than control lobsters.

No changes in gill epithelial tissue or other tissue aberrations were detected in any of the larval stages between oil exposed and control groups (Figures 5 and 6 ).

Effects of chronic exposure to oil contaminated seawater or sediments on juvenile lobsters

Postlarval lobsters exposed to $0.25 \mathrm{ppm}$ South Louisiana crude oil for 78 days showed no change in respiration rates, ammonia excretion rates or $0: N$ ratios in comparison with control animals. Unlike larval lobsters, no disruption in energetics as a result of oil exposure could be detected. 
Table 6. Dry weight and biochemical composition of the four larval stages and the first postlarval stage of the American lobster from control and oil-exposed groupsa

\begin{tabular}{|c|c|c|c|c|c|c|}
\hline Component & Group & I & II & $\begin{array}{l}\text { Stage } \\
\text { I I I }\end{array}$ & IV & $\mathrm{V}^{\mathrm{b}}$ \\
\hline ry weight, $\mathrm{mg}^{\mathrm{C}}$ & $\begin{array}{l}\text { control } \\
\text { oil }\end{array}$ & $\begin{array}{l}1.0 \pm 0.1 \\
1.0 \pm 0.1\end{array}$ & $\begin{array}{l}1.9 \pm 0.1 \\
2.0 \pm 0.1\end{array}$ & $\begin{array}{l}2.9 \pm 0.1 \\
2.9 \pm 0.1\end{array}$ & $\begin{array}{l}7.2 \pm 0.2 \\
7.2 \pm 0.3\end{array}$ & $\begin{array}{l}9.0+0.2 \\
8.9 \pm 0.3\end{array}$ \\
\hline ash d & $\begin{array}{l}\text { control } \\
\text { oil }\end{array}$ & $\begin{array}{l}18.4 \pm 0.2 \\
18.5 \pm 0.3\end{array}$ & $\begin{array}{l}19.0 \pm 0.04 \\
18.9 \pm 0.03\end{array}$ & $\begin{array}{l}21.2 \pm 0.5 \\
20.5 \pm 0.5\end{array}$ & $\begin{array}{l}24.5 \pm 1.0 \\
22.5 \pm 1.0\end{array}$ & $\begin{array}{l}23.0 \pm 0.5 \\
22.5 \pm 0.5\end{array}$ \\
\hline protein $d$ & $\begin{array}{l}\text { control } \\
\text { oil }\end{array}$ & $\begin{array}{l}68.8 \pm 0.2 \\
72.9 \pm 1.0\end{array}$ & $\begin{array}{l}65.0 \pm 0.8 \\
71.0 \pm 0.5\end{array}$ & $\begin{array}{l}63.5 \pm 1.0 \\
66.3 \pm 0.7\end{array}$ & $\begin{array}{l}62.0 \pm 0.6 \\
64.6 \pm 0.6\end{array}$ & $\begin{array}{l}62.5 \pm 0.8 \\
64.2 \pm 0.6\end{array}$ \\
\hline carbohydrate & $\begin{array}{l}\text { control } \\
\text { oil }\end{array}$ & $\begin{array}{l}2.0 \pm 0.1 \\
1.9 \pm 0.1\end{array}$ & $\begin{array}{l}1.9 \pm 0.1 \\
1.9 \pm 0.1\end{array}$ & $\begin{array}{l}1.5 \pm 0.1 \\
1.5 \pm 0.1\end{array}$ & $\begin{array}{l}1.4 \pm 0.1 \\
1.4 \pm 0.1\end{array}$ & $\begin{array}{l}1.4 \pm 0.1 \\
1.4 \pm 0.1\end{array}$ \\
\hline lipid d & $\begin{array}{l}\text { control } \\
\text { oil }\end{array}$ & $\begin{array}{l}5.9 \pm 0.2 \\
4.5 \pm 0.2\end{array}$ & $\begin{array}{l}5.3 \pm 0.5 \\
3.9 \pm 0.4\end{array}$ & $\begin{array}{l}5.4 \pm 0.5 \\
4.0 \pm 0.5\end{array}$ & $\begin{array}{l}4.2 \pm 0.3 \\
3.7 \pm 0.2\end{array}$ & $\begin{array}{l}3.2 \pm 0.2 \\
3.1 \pm 0.2\end{array}$ \\
\hline rotein:lipid & $\begin{array}{l}\text { control } \\
\text { oil }\end{array}$ & $\begin{array}{l}11.7 \\
16.2\end{array}$ & $\begin{array}{l}12.3 \\
18.2\end{array}$ & $\begin{array}{l}11.8 \\
16.6\end{array}$ & $\begin{array}{l}14.8 \\
17.5\end{array}$ & $\begin{array}{l}19.5 \\
20.7\end{array}$ \\
\hline
\end{tabular}

a Mean values of 6 determinations \pm 1 S.E.

b Sampled at the end of the post-exposure period

C Dried for $24 \mathrm{~h}$ at $60^{\circ} \mathrm{C}$

d \% dry weight basis 


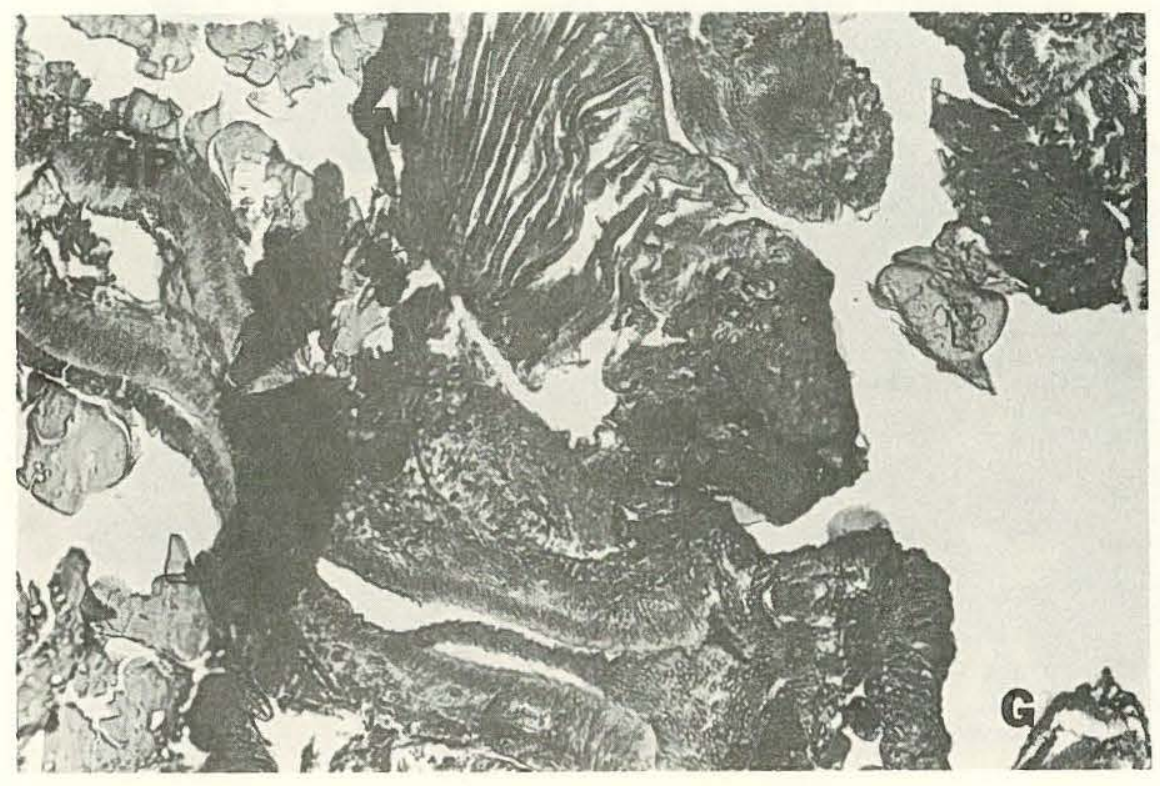

\section{$0.4 \mathrm{~mm}$}

Figure 5. Cross section of stage IV lobster larvae from control experiments; 200 x; G-gi11, M-muscle, HP-hepatopancreas. 


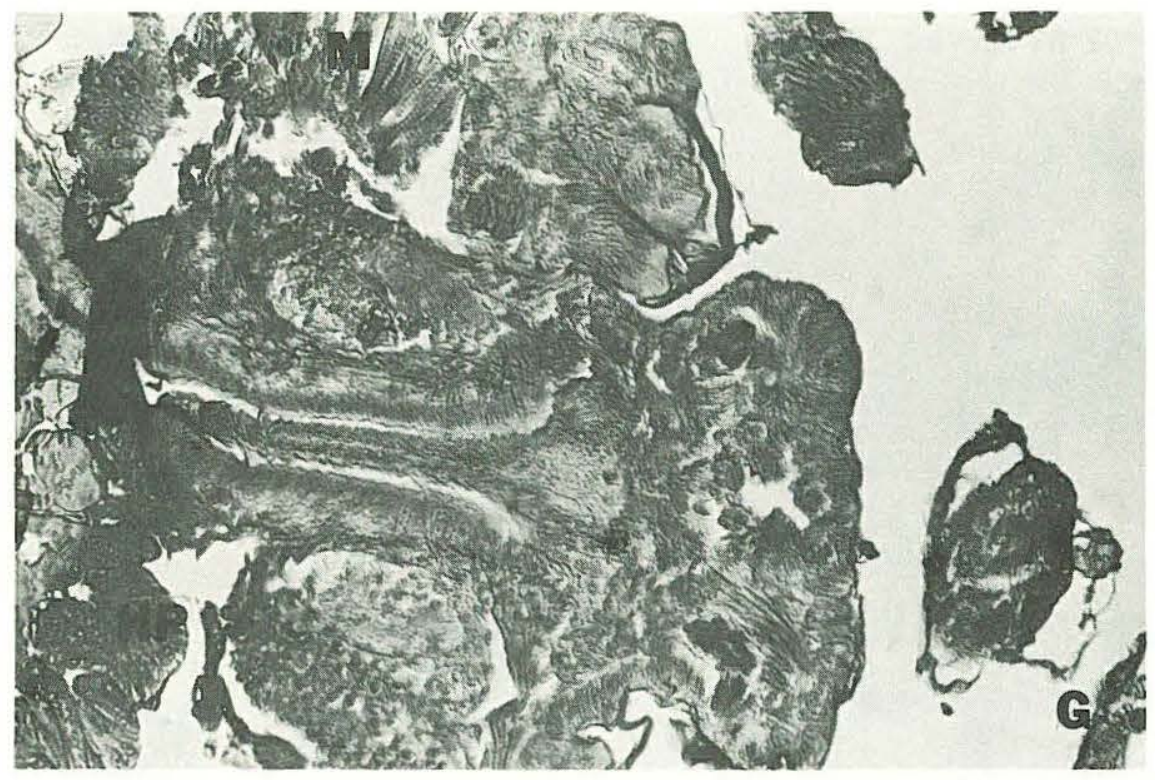
$0.4 \mathrm{~mm}$

Figure 6. Cross section of stage IV larvae from 0i1-contaminated seawater; 200 x; G-gi11, M-muscle, HP-hepatopancreas. 
Respiration rates, ammonia excretion rates and $0: \mathrm{N}$ ratios of control and oil exposed lobsters are presented in Figures 7, 8 and 9, respectively; ANCOVA tables relating respiration rates and excretion rates to wet weight of experimental and control animals are presented in Tables 7 and 8, respectively.

Molting activity was not synchronous between the two groups (Figure 10) but weight increases and the number of molts during the experimental period were not significantly different in the two groups. The growth of experimental and control animals is presented in Figure 11 and the ANCOVA table relating weight increase with time is presented in Table 9.

There was no mortality in the control group; however, $10 \%$ mortality was observed in the oil exposed group, but this was possibly due to the combined effect of thermal stress to molting animals as a result of a power failure, rather than a direct effect of oil exposure alone. No difference in feeding rates, feeding behavior or histological aberrations (Figures 12, 13 and 14) could be detected.

For postlarval lobsters exposed to oil contaminated sediments, reductions in respiration rate were detected within the first 48 hours of exposure and sustanied at lower than control levels for the first 30 days of exposure (Table 10). The sediment sample taken on day 1 had a full range of hydrocarbons characteristic of South Louisiana crude 0il; the short chained $n$ paraffin hydrocarbons were clearly distinguishable with representative peaks down to $C_{10}$; peaks were indistinguishable below $C_{10}$ because of an increasing background envelope. In the day 15 and day 31 samples there was a definite decrease and/or elimination of 


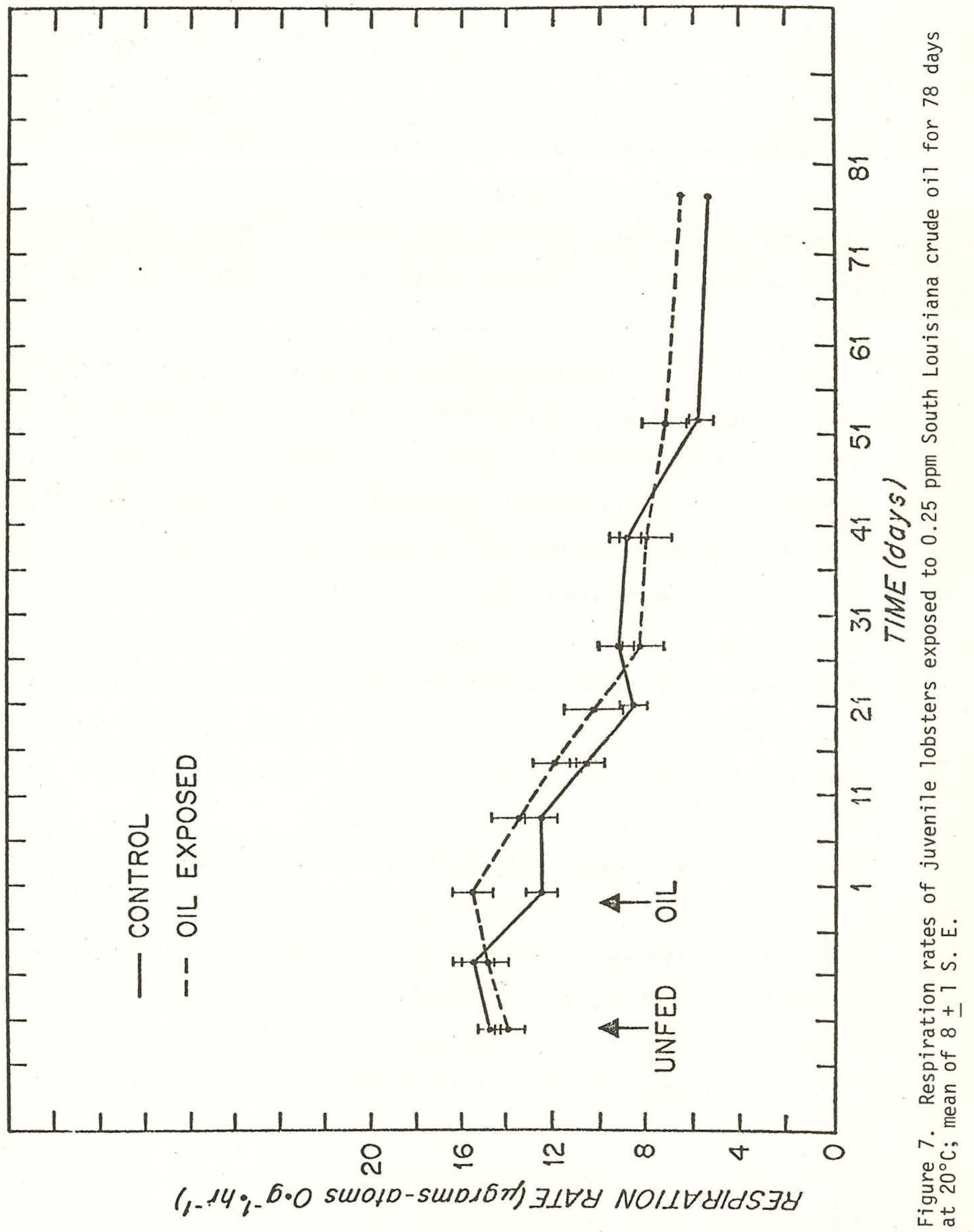




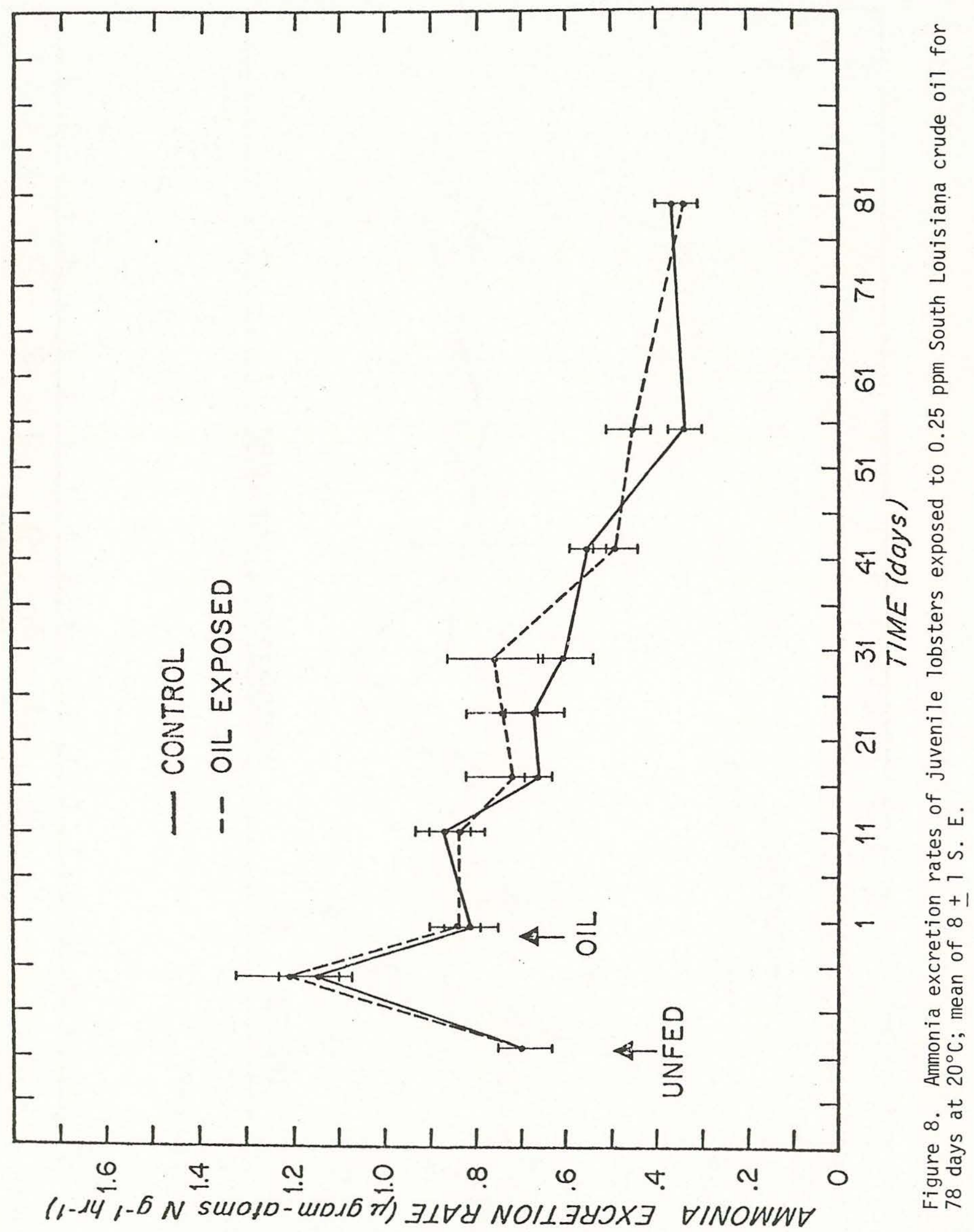


$-32-$

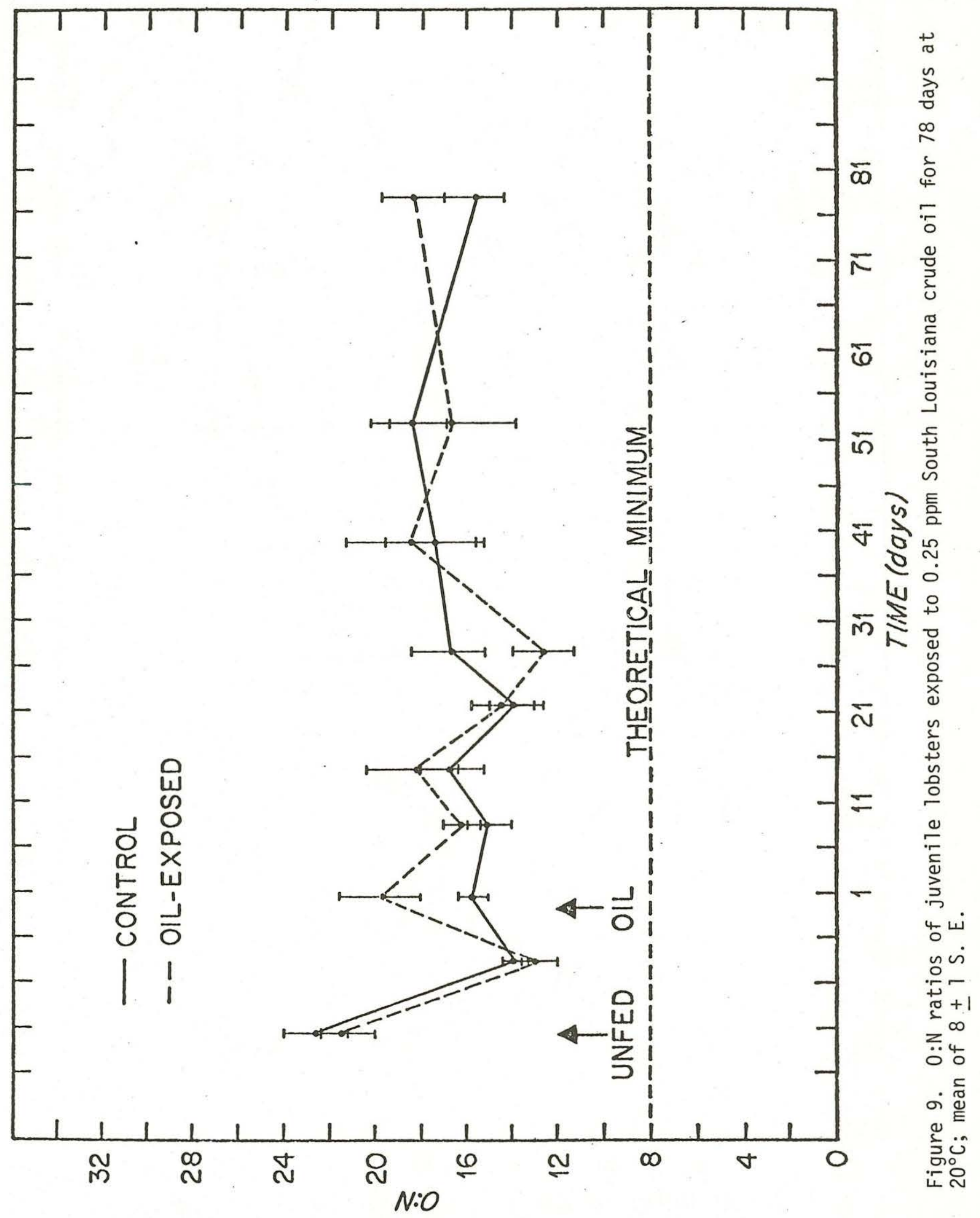


Table 7. ANCOVA for respiration rates as a function of wet weight for control vs. oil-exposed lobsters.

\begin{tabular}{lcccc}
\hline Source of variance & d.f. & S.S. & M.S. & F-ratio \\
\hline $\begin{array}{l}\text { Equality of adjusted } \\
\text { means }\end{array}$ & 1 & 0.0007 & 0.0007 & $0.05^{\star}$ \\
& 185 & 2.7606 & 0.0149 & \\
Error & 1 & 0.0280 & 0.0280 & $1.88^{*}$ \\
Equality of slopes & 184 & 2.7326 & 0.0149 & \\
Error & & & & \\
\hline$* P>0.05$ & & & &
\end{tabular}


Table 8. ANCOVA for ammonia excretion rates as a function of wet weight for control vs. oil-exposed lobsters.

\begin{tabular}{|c|c|c|c|c|}
\hline Source of variance & d.f. & S.S. & M.S. & F-ratio \\
\hline \multirow[t]{2}{*}{$\begin{array}{l}\text { Equality of adjusted } \\
\text { means }\end{array}$} & 1 & 0.0057 & 0.0057 & \\
\hline & & & & $0.38 *$ \\
\hline Error & 185 & 2.8024 & 0.0151 & \\
\hline \multirow[t]{2}{*}{ Equality of slopes } & 1 & 0.0003 & 0.0003 & \\
\hline & & & & $0.02^{\star}$ \\
\hline Error & 184 & 2.8020 & 0.0152 & \\
\hline
\end{tabular}




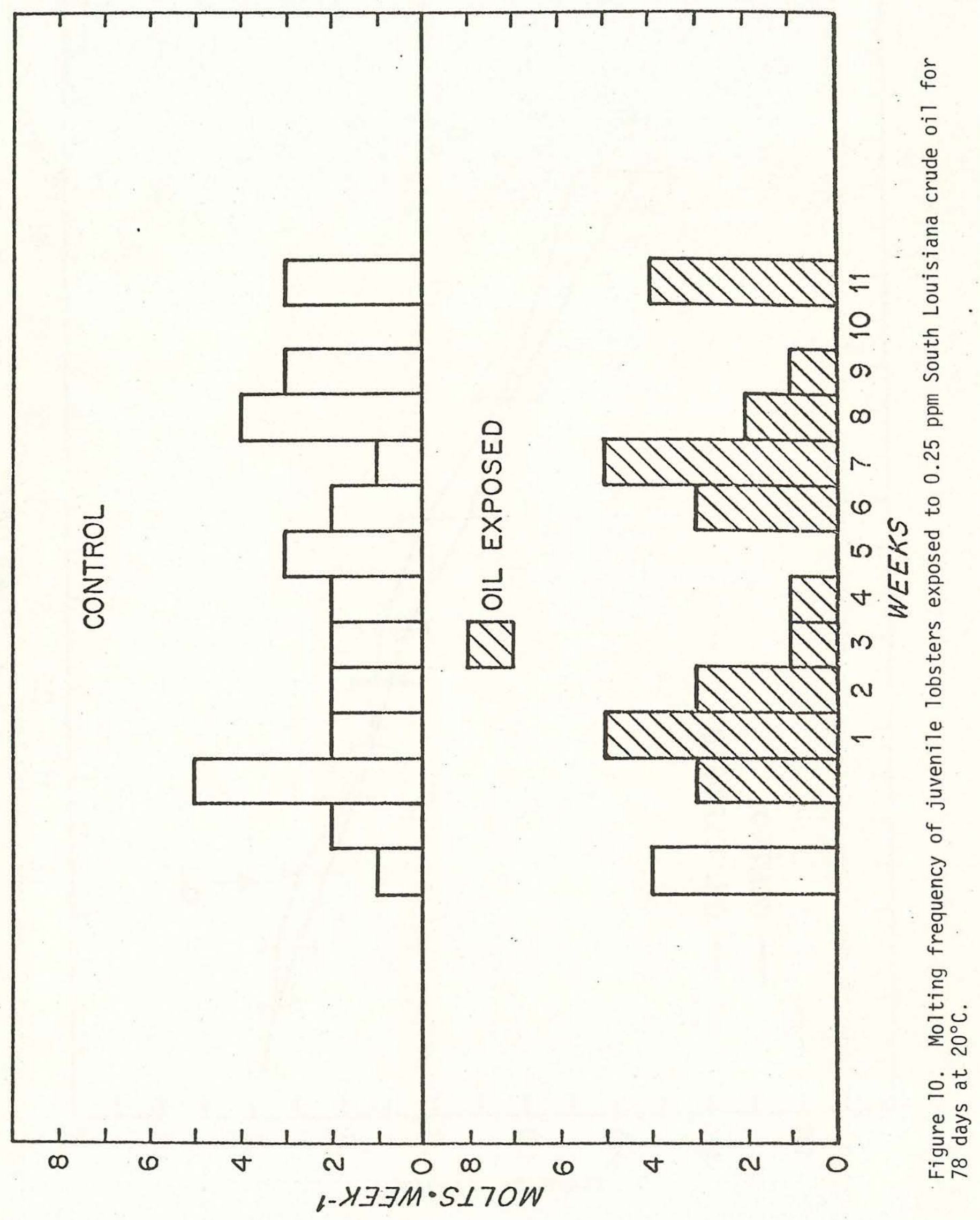




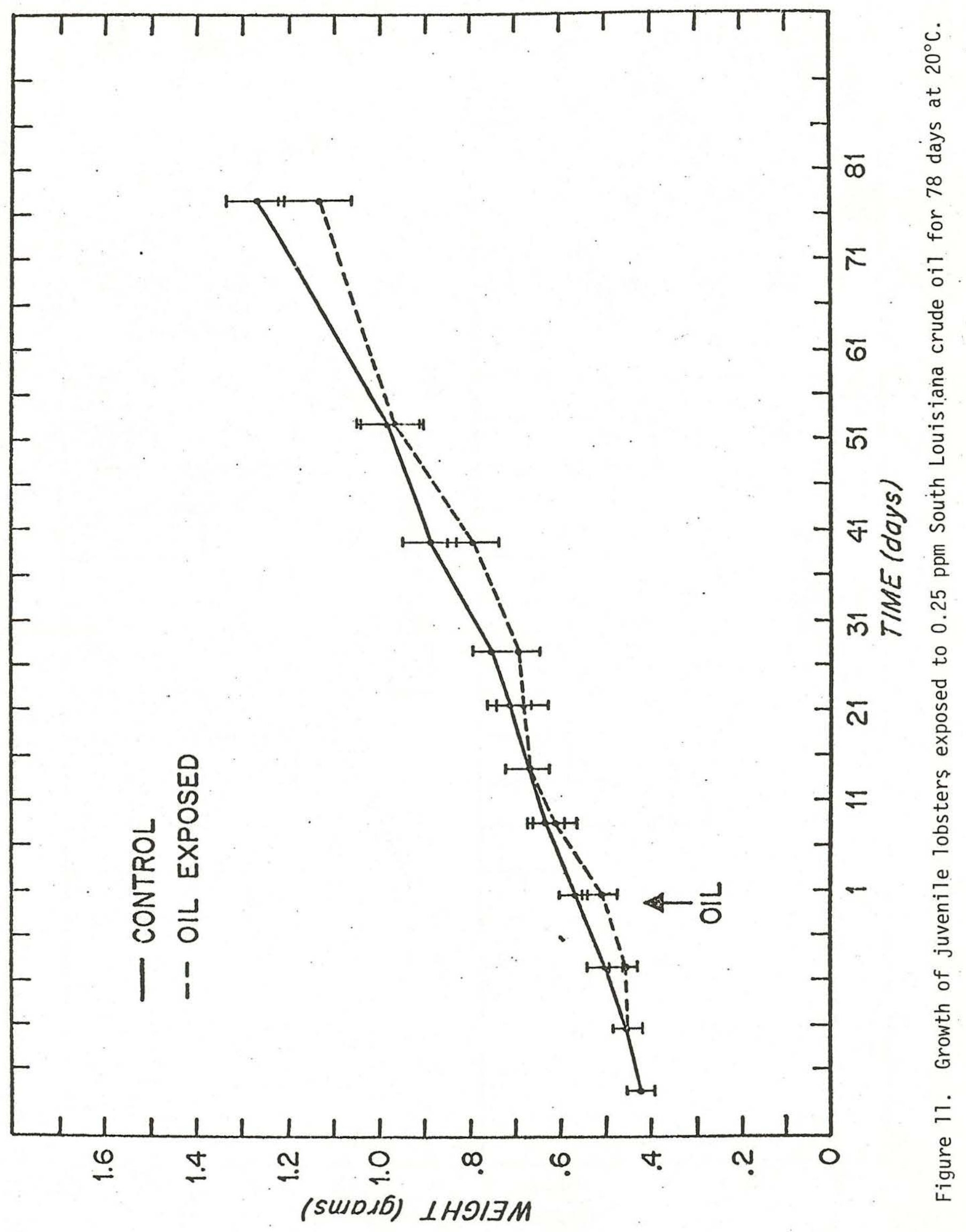


Table 9. ANCOVA for weight increase as a function of time for control vs. oil-exposed lobsters after the introduction of oil into the system.

$\begin{array}{lllll}\text { Source of variance } & \text { df } & \text { SS } & \text { MS }\end{array}$

Equality of adjusted means

$1 \quad 0.1215 \quad 0.1215$

$3.79 *$

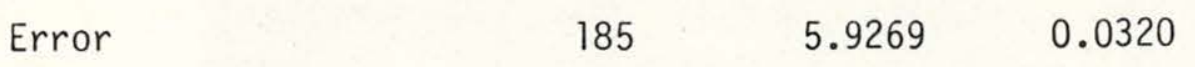

\begin{tabular}{|c|c|c|c|c|}
\hline Equality of slopes & 1 & 0.0310 & 0.0310 & \\
\hline & & & & $0.97 *$ \\
\hline Error & 184 & 5.8959 & 0.0320 & \\
\hline
\end{tabular}

$\star P>0.05$ 

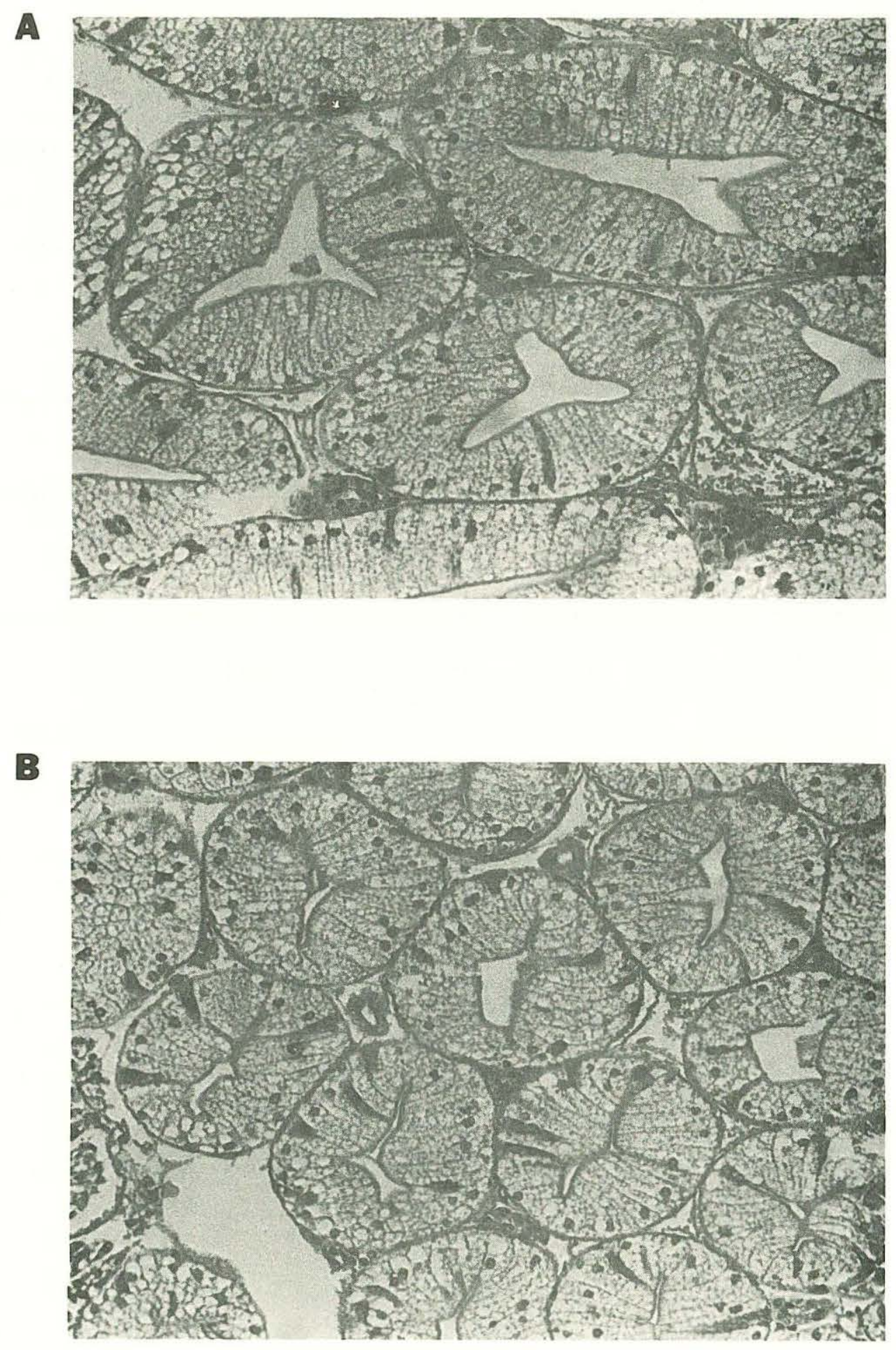

\section{$0.15 \mathrm{~mm}$}

Figure 12. Cross section of hepatopancreas taken from juvenile lobster; A-control, B-oil-exposed; 500x. 

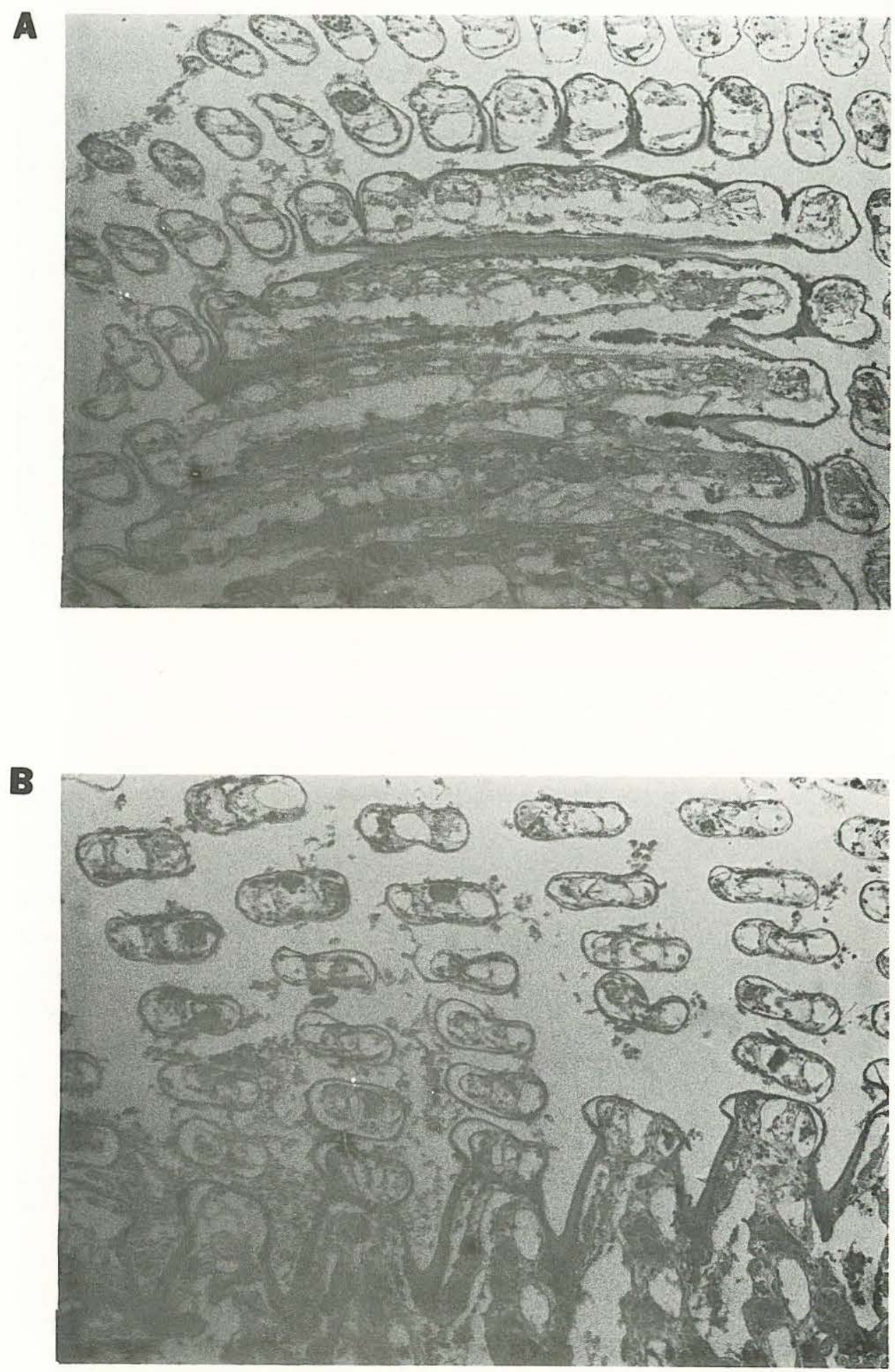

\section{$0.4 \mathrm{~mm}$}

Figure 13. Sagittal section of gill taken from juvenile lobster; A-control, B-oil-exposed; $200 \mathrm{x}$. 
A

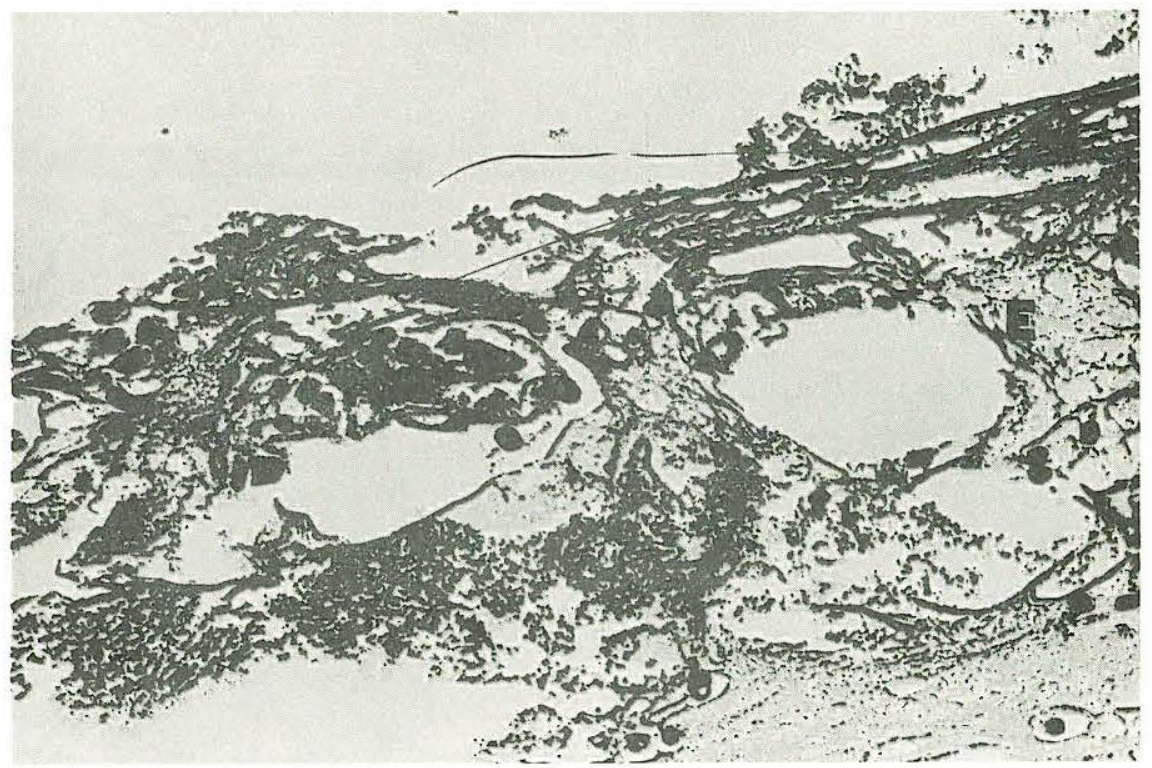

B

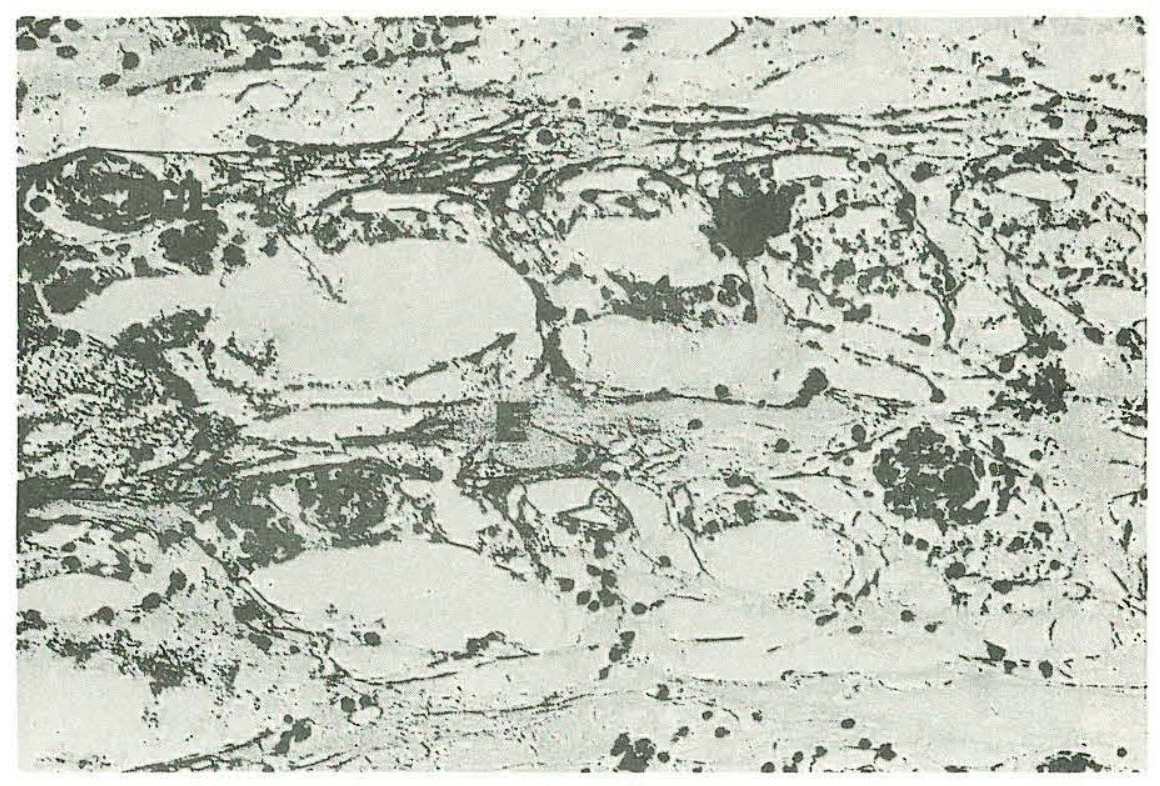

$0.15 \mathrm{~mm}$

Figure 14. Cross section of gi11 taken from juvenile lobster; A-control, B-oil-exposed; 500 x. TGL-tegmental gland, E-epithelium. 
Table 10. Respiration rates of postlarval lobsters exposed to oil-contaminated sediments.

\begin{tabular}{|c|c|c|}
\hline \multirow[t]{2}{*}{ Day } & \multicolumn{2}{|c|}{ Respiration rates $-\mu 10_{2} / \mathrm{h} / \mathrm{g}$ wet weight ${ }^{2}$} \\
\hline & Control & 0 il-exposed \\
\hline$p^{b}$ & $121.8 \pm 8.1$ & $119.5 \pm 7.5$ \\
\hline 3 & $120.5 \pm 7.0$ & $94.9 \pm 1.5$ \\
\hline 6 & $111.1+3.2$ & $100.0 \pm 5.7$ \\
\hline 15 & $123.1+5.3$ & $92.1 \pm 4.9$ \\
\hline 21 & $130.2 \pm 5.5$ & $98.6 \pm 5.3$ \\
\hline $28^{C}$ & $101.9 \pm 2.5$ & $86.1 \pm 5.0$ \\
\hline 34 & $108.8 \pm 5.2$ & $80.9 \pm 2.6$ \\
\hline 40 & $111.0 \pm 2.5$ & $104.0 \pm 2.5$ \\
\hline 48 & $105.2 \pm 3.2$ & $108.3 \pm 3.5$ \\
\hline
\end{tabular}
a Mean of eight determinations \pm 1 S.E.
b Stage $x$, mean weight $=1.2 \mathrm{~g}$
C Stage XI, mean weight $=1.8 \mathrm{~g}$ 
Table 11. Hydrocarbon concentrations of $0 i 1$ contaminated sediments. ${ }^{a}$

Day

Control ppm

0i1-Contaminated ppm

1

0.01

2.50

15

0.01

0.30

30

0.01

0.05

a Concentration of finer than $0.25 \mathrm{~mm}$ fraction. 
n-paraffins and some decrease occurred in the aromatic fractions as well. At day 31 hydrocarbon concentrations of the sediment samples were negligible and restoration of normal respiration rates were observed shortly thereafter. Molting activity and feeding activity were normal in both the control and exposed groups and no histological aberrations were observed. The reductions in respiratory activity could be the result of the hydrocarbon content of pore waters and not direct sediment exposure. Effects of ingestion of oil contaminated Artemia nauplii on larval and postlarval lobsters

Survial of Artemia nauplii hatched in concentrations of crude 0 il ranging from 0.125 to $1.000 \mathrm{ppm}$ are presented in Table 12. There was no significant difference in time to hatching between control and exposure groups and hatching normally began within $24 \mathrm{~h}$. There were significant differences, however, in hatching survival and behavior of the hatched nauplii between control and oil-exposed groups. Hatching survival relative to control values is presented in Table 12 and although a consistent pattern could not be correlated with exposure concentration, reduced survival was observed at each exposure concentration. When cyst shells were shed by the nauplii, control nauplii sank to the bottom of the culture vessel whereas ones exposed to the various oil concentrations floated just below the surface of the oil-seawater mixture. Nauplii hatched in the various oil concentrations also appeared to be more sluggish in comparison with the control nauplii. 
$-44-$

Table 12. Hatching survival of Artemia exposed to South Louisiana crude oil relative to control values

\begin{tabular}{cc}
\hline Concentration, ppm & \% Survival \\
\hline 0.125 & 82.3 \\
0.250 & 71.3 \\
0.500 & 55.0 \\
0.750 & 68.9 \\
1.000 & 71.3 \\
\hline
\end{tabular}




$$
-45-
$$

Table 13. Survival of larval and postlarval lobsters exposed to $0.25 \mathrm{ppm}$ South Louisiana crude oil through seawater exposure and ingestion of oil contaminated Artemia nauplii

\begin{tabular}{|c|c|c|c|}
\hline Stage & $\underset{\%}{\text { Control }}$ & 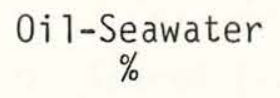 & $\underset{\%}{0 i 1-N a u p l i i}$ \\
\hline I & $\begin{array}{l}43.2 \\
(1.0)\end{array}$ & $\begin{array}{l}47.5 \\
(1.0)\end{array}$ & $\begin{array}{l}45.0 \\
(1.0)\end{array}$ \\
\hline I I & $\begin{array}{l}42.5 \\
(1.2)\end{array}$ & $\begin{array}{l}46.5 \\
(1.2)\end{array}$ & $\begin{array}{l}45.0 \\
(1.0)\end{array}$ \\
\hline I I I & $\begin{array}{l}50.0 \\
(1.8)\end{array}$ & $\begin{array}{l}51.1 \\
(1.6)\end{array}$ & $\begin{array}{l}42.9 \\
(1.6)\end{array}$ \\
\hline IV & $\begin{array}{l}92.7 \\
(1.5)\end{array}$ & $\begin{array}{c}96.0 \\
(91.5)\end{array}$ & $\begin{array}{l}83.5 \\
(0.9)\end{array}$ \\
\hline V & $\begin{array}{l}92.5 \\
(0.5)\end{array}$ & $\begin{array}{l}92.5 \\
(0.5)\end{array}$ & $\begin{array}{l}92.5 \\
(0.5)\end{array}$ \\
\hline
\end{tabular}

Mean replicate of 12 assays ( \pm 1 S.E.) 
To be consistent with seawater exposure experiments, nauplii hatched in $0.250 \mathrm{ppm}$ SLCO were used in experiments to evaluate the effects of ingestion of contaminated food on the energetics of larval and juvenile lobsters.

Survival of all larval stages and the first postlarval stage fed oil contaminated Artemia nauplii are compared with control animals and animals exposed to oil through seawater exposure in Table 13. There was no significant difference in survival of the first two larval stages among the three exposure groups; however, slightly reduced survival rates were observed among stage III and IV larvae fed oil contaminated Artemia nauplii. Among all groups survival rates of stage IV larvae and stage $V$ postlarvae were significantly higher than survival rates of the early developmental stages. There was also a significant delay in molting to subsequent stages among all stages fed the oil contaminated food source. Respiration rates of larval and postlarval lobsters are presented in Figure 3 and Table 14. For larvae exposed to oil contaminated seawater, only stage I larvae showed a significant reduction in respiration rate at the $24 \mathrm{~h}$ sampling period; all larval stages showed reductions, however, after $72 \mathrm{~h}$ of exposure. For larval and postlarval lobsters fed an oil contaminated food source, all stages with the exception of stage I larvae had reduced respiration rates relative to control values at both the $24 \mathrm{~h}$ and $72 \mathrm{~h}$ sampling periods; stage I larvae only had reduced respiration rates at the $72 \mathrm{~h}$ sampling period (Tables 15 and 16). 
Table 14. Respiration rates ( $\mu \mathrm{l} 0_{2} / \mathrm{h} / \mathrm{mg}$ dry weight) of larval and postlarval lobsters exposed to $0.25 \mathrm{ppm}$ South Louisiana crude oil through seawater exposure and ingestion of $0 i 1$ contaminated Artemia nauplii

\begin{tabular}{|c|c|c|c|c|c|c|}
\hline \multirow[t]{2}{*}{ Stage } & \multicolumn{2}{|c|}{ Control } & \multicolumn{2}{|c|}{ 0i1-Seawater } & \multicolumn{2}{|c|}{ 0i1-Nauplii } \\
\hline & $24 h$ & $72 \mathrm{~h}$ & $24 \mathrm{~h}$ & $72 \mathrm{~h}$ & $24 h$ & $72 \mathrm{~h}$ \\
\hline I & $\begin{array}{c}2.5 \\
(0.1)\end{array}$ & $\begin{array}{l}2.7 \\
(0.2)\end{array}$ & $\begin{array}{c}1.5 \\
(0.1)\end{array}$ & $\begin{array}{c}1.5 \\
(0.1)\end{array}$ & $\begin{array}{l}2.4 \\
(0.2)\end{array}$ & $\begin{array}{c}2.2 \\
(0.2)\end{array}$ \\
\hline I I & $\begin{array}{c}2.9 \\
(0.2)\end{array}$ & $\begin{array}{c}2.9 \\
(0.1)\end{array}$ & $\begin{array}{c}2.5 \\
(0.1)\end{array}$ & $\begin{array}{c}2.0 \\
(0.2)\end{array}$ & $\begin{array}{c}2.0 \\
(0.2)\end{array}$ & $\begin{array}{c}1.5 \\
(0.2)\end{array}$ \\
\hline I I I & $\begin{array}{c}3.2 \\
(0.2)\end{array}$ & $\begin{array}{c}3.3 \\
(0.2)\end{array}$ & $\begin{array}{c}3.0 \\
(0.2)\end{array}$ & $\begin{array}{c}2.2 \\
(0.2)\end{array}$ & $\begin{array}{c}2.5 \\
(0.1)\end{array}$ & $\begin{array}{c}2.2 \\
(0.2)\end{array}$ \\
\hline IV & $\begin{array}{c}3.8 \\
(0.2)\end{array}$ & $\begin{array}{c}3.7 \\
(0.3)\end{array}$ & $\begin{array}{c}3.7 \\
(0.3)\end{array}$ & $\begin{array}{c}2.9 \\
(0.2)\end{array}$ & $\begin{array}{c}3.2 \\
(0.1)\end{array}$ & $\begin{array}{c}2.9 \\
(0.2)\end{array}$ \\
\hline V & $\begin{array}{c}2.0 \\
(0.1)\end{array}$ & $\begin{array}{c}1.8 \\
(0.1)\end{array}$ & - & - & $\begin{array}{c}1.5 \\
(0.2)\end{array}$ & $\begin{array}{c}1.2 \\
(0.1)\end{array}$ \\
\hline
\end{tabular}

Mean of 8 replicates $( \pm 1$ S.E.) 
Table 15. Analysis of variance of respiration rates measured for each larval stage and the first postlarval stage of the American lobster at $24 \mathrm{~h}$ and $72 \mathrm{~h}$ during exposure through ingestion of oil contaminated Artemia nauplii and compared with control larvae.

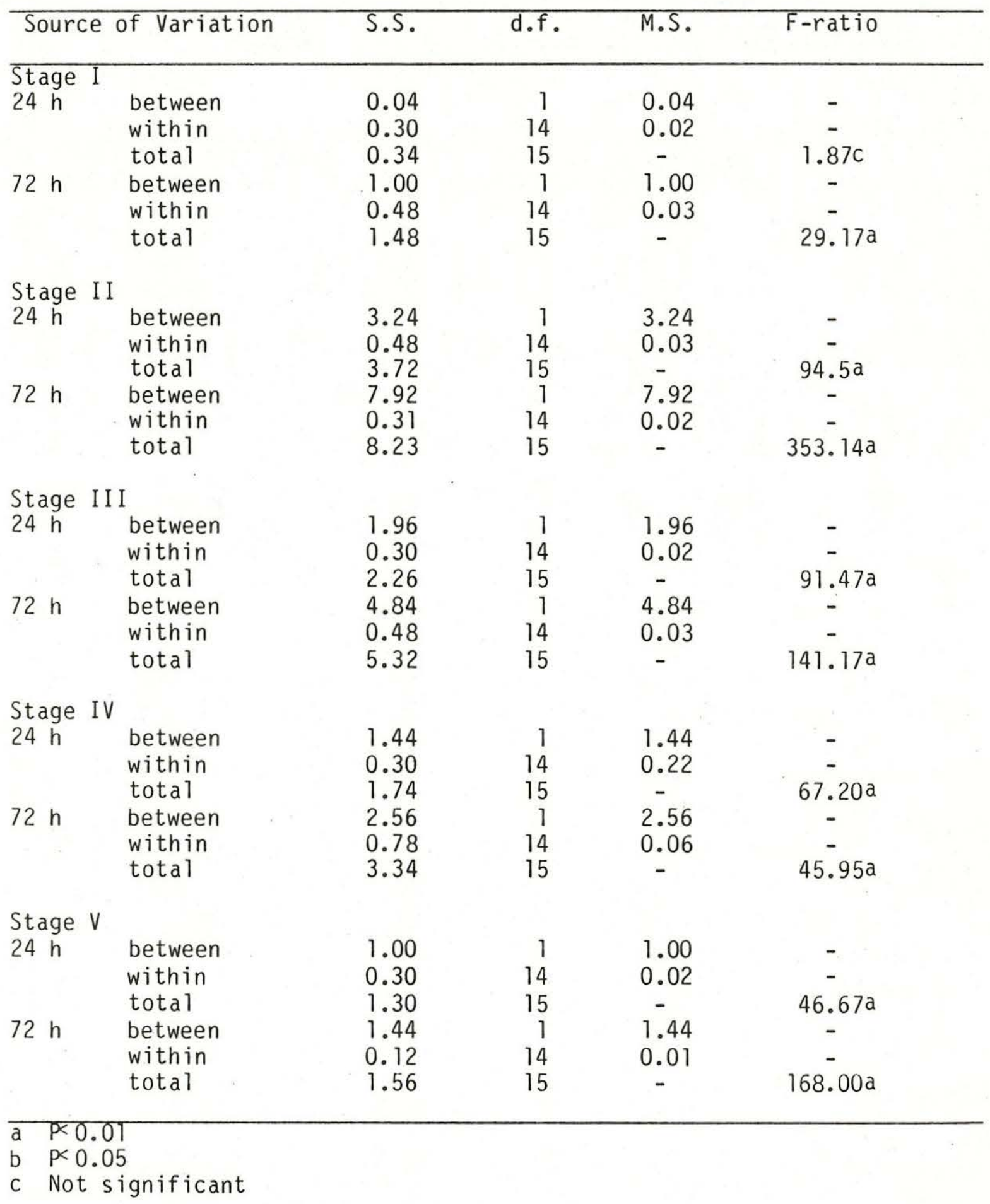


Table 16. Analysis of variance of respiration rates measured for each larval stage of the American lobster at $24 \mathrm{~h}$ and $72 \mathrm{~h}$ during exposure through ingestion of oil contaminated Artemia nauplii and compared with larvae exposed to oil-seawater mixtures.

\begin{tabular}{|c|c|c|c|c|c|}
\hline Sour & ce of Variation & S.S. & d.f. & M.S. & F-ratio \\
\hline \multicolumn{6}{|c|}{ Stage I } \\
\hline \multirow[t]{3}{*}{$24 \mathrm{~h}$} & between & 3.24 & 1 & 3.24 & - \\
\hline & within & 0.30 & 14 & 0.02 & - \\
\hline & total & 3.54 & 15 & - & $151.20 a$ \\
\hline \multirow[t]{3}{*}{$72 \mathrm{~h}$} & between & 1.96 & 1 & 1.96 & - \\
\hline & within & 0.30 & 14 & 0.02 & - \\
\hline & total & 2.26 & 15 & - & $91.47 a$ \\
\hline \multicolumn{6}{|c|}{ Stage II } \\
\hline \multirow[t]{3}{*}{$24 \mathrm{~h}$} & between & 1.00 & 1 & 1.00 & - \\
\hline & within & 0.30 & 14 & 0.02 & - \\
\hline & total & 1.30 & 15 & - & $46.67 a$ \\
\hline \multirow[t]{3}{*}{$72 \mathrm{~h}$} & between & 1.19 & 1 & 1.19 & - \\
\hline & within & 0.29 & 14 & 0.02 & - \\
\hline & total & 1.48 & 15 & - & $26.90 a$ \\
\hline \multicolumn{6}{|c|}{ Stage III } \\
\hline \multirow[t]{3}{*}{$24 \mathrm{~h}$} & between & 1.00 & 1 & 1.00 & - \\
\hline & within & 0.30 & 14 & 0.02 & - \\
\hline & total & 1.30 & 15 & - & $46.67 a$ \\
\hline \multirow[t]{3}{*}{$72 \mathrm{~h}$} & between & 0.00 & 1 & 0.00 & - \\
\hline & within & 0.48 & 14 & 0.03 & - \\
\hline & total & 0.48 & 15 & - & $0.00 \mathrm{C}$ \\
\hline \multicolumn{6}{|c|}{ Stage IV } \\
\hline \multirow[t]{3}{*}{$24 \mathrm{~h}$} & between & 1.00 & 1 & 1.00 & - \\
\hline & within & 0.60 & 14 & 0.04 & - \\
\hline & total & 1.60 & 15 & - & $23.33 a$ \\
\hline \multirow[t]{3}{*}{$72 \mathrm{~h}$} & between & 0.00 & 1 & 0.00 & - \\
\hline & within & 0.48 & 14 & 0.03 & - \\
\hline & total & 0.48 & 15 & - & $0.00 \mathrm{a}$ \\
\hline
\end{tabular}
a $P<0.01$
b $P<0.05$
c Not significant 
Table 17. Ammonia excretion rates ( $\mu \mathrm{g} \mathrm{NH} 4-\mathrm{N} / \mathrm{h} / \mathrm{mg}$ dry weight) of larval and postlarval lobsters exposed to $0.25 \mathrm{ppm}$ South Louisiana crude oil through seawater exposure and ingestion of oil contaminated Artemia nauplii.

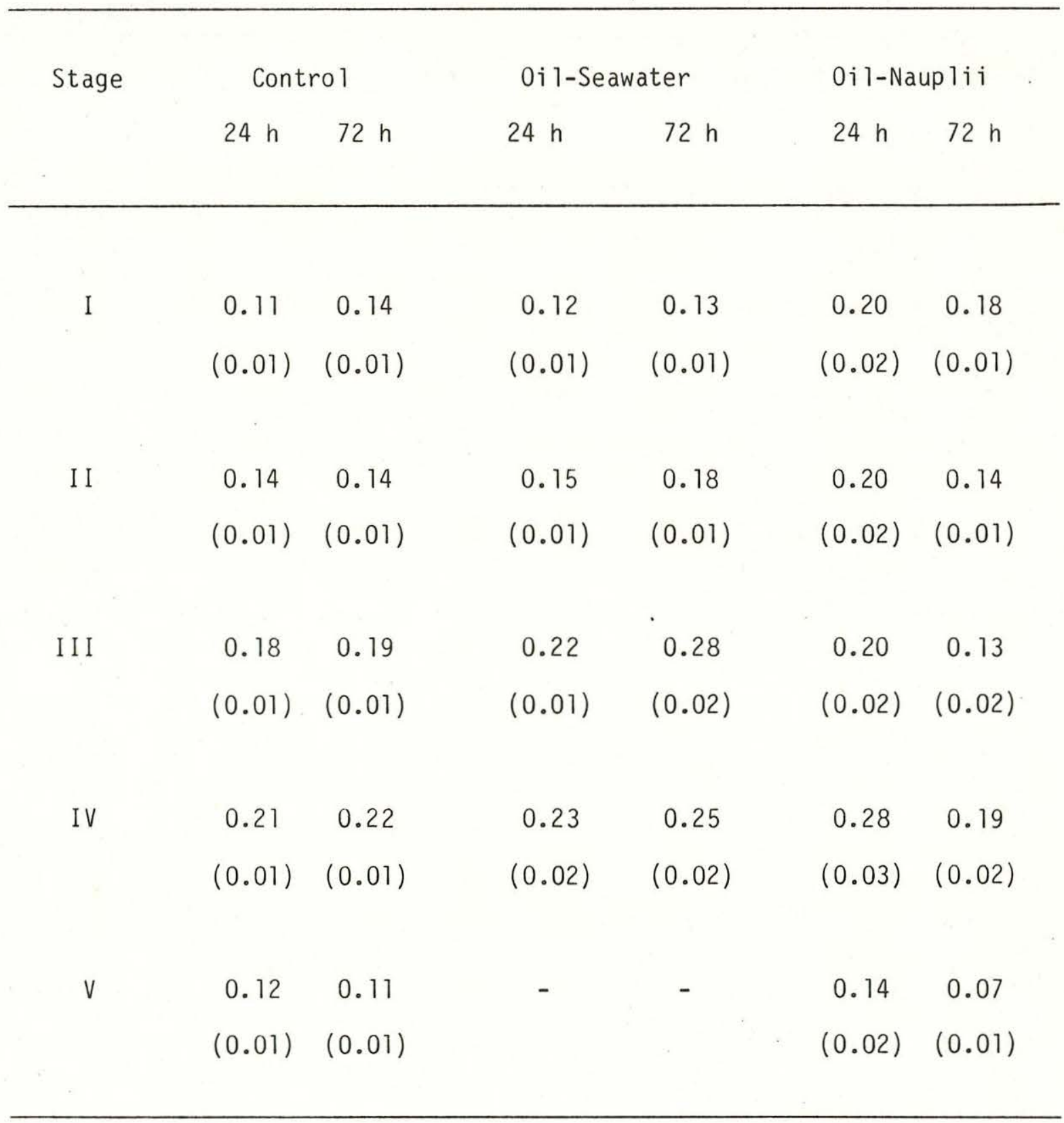

Mean of 8 replicates $( \pm 1$ S.E.) 
Table 18. 0:N ratios of larval and postlarval lobsters exposed to 0.25 ppm South Louisiana crude oil through seawater exposure and ingestion of oil contaminated Artemia nauplii.

\begin{tabular}{|c|c|c|c|c|c|c|}
\hline \multirow[t]{2}{*}{ Stage } & \multicolumn{2}{|c|}{ Control } & \multicolumn{2}{|c|}{ 0i1-Seawater } & \multicolumn{2}{|c|}{ 0il-Nauplii } \\
\hline & $24 h$ & $72 \mathrm{~h}$ & $24 h$ & $72 \mathrm{~h}$ & $24 h$ & $72 \mathrm{~h}$ \\
\hline I & 27.2 & 27.3 & 17.0 & 14.9 & 17.2 & 14.9 \\
\hline I I & 27.6 & 28.3 & 22.4 & 14.8 & 15.3 & 13.0 \\
\hline I I I & 22.0 & 21.1 & 17.9 & 9.6 & 15.3 & 19.6 \\
\hline IV & 22.6 & 21.1 & 20.6 & 14.9 & 14.3 & 19.5 \\
\hline V & 22.3 & 21.5 & - & - & 15.6 & 19.5 \\
\hline
\end{tabular}

Atomic ratio of oxygen consumed to $\mathrm{NH}_{4}^{+}-\mathrm{N}$ excreted 
Table 19. Analysis of variance of ammonia excretion rates measured for each larval stage and the first postlarval stage of the American lobster at $24 \mathrm{~h}$ and $72 \mathrm{~h}$ during exposure through ingestion of oil contaminated Artemia nauplii and compared with control larvae.

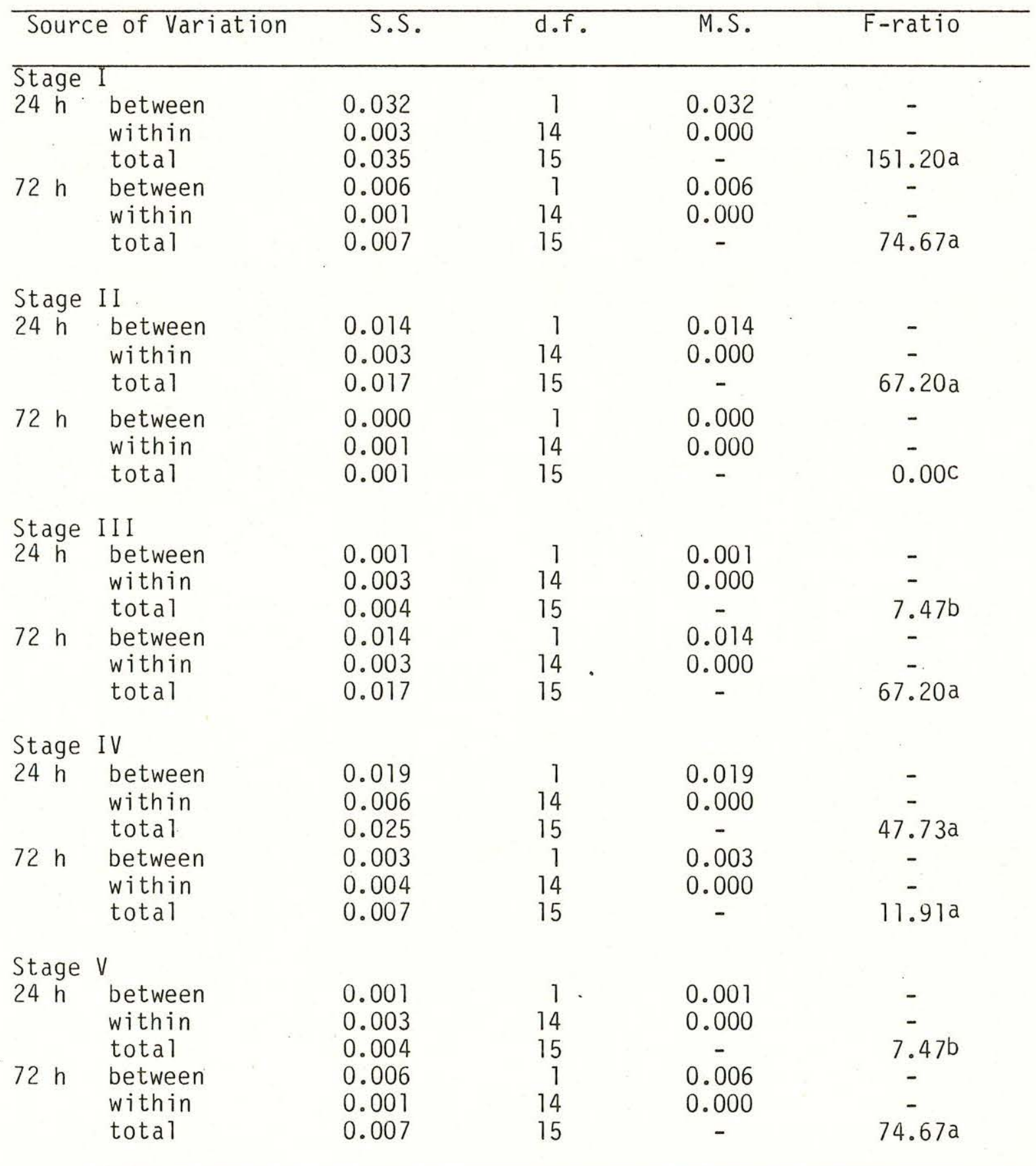

a $\quad p<0.01$

b $\quad P<0.05$

c Not significant 
Table 20. Analysis of variance of ammonia excretion rates measured for each larval stage of the American lobster at $24 \mathrm{~h}$ and $72 \mathrm{~h}$ during exposure through ingestion of oil contaminated Artemia nauplii and compared with larvae exposed to oil-seawater mixtures.

\begin{tabular}{|c|c|c|c|c|c|}
\hline Sourc & e of Variation & S.S. & d.f. & M.S. & F-ratio \\
\hline \multicolumn{6}{|c|}{ Stage I } \\
\hline \multirow[t]{3}{*}{$24 \mathrm{~h}$} & between & 0.025 & 1 & 0.025 & - \\
\hline & within & 0.003 & 14 & 0.000 & - \\
\hline & total & 0.028 & 15 & - & $119.47 a$ \\
\hline \multirow[t]{3}{*}{$72 \mathrm{~h}$} & between & 0.010 & 1 & 0.010 & - \\
\hline & within & 0.001 & 14 & 0.000 & - \\
\hline & total & 0.011 & 15 & - & $116.67 a$ \\
\hline \multicolumn{6}{|c|}{ Stage I I } \\
\hline \multirow[t]{3}{*}{$24 \mathrm{~h}$} & between & 0.010 & 1 & 0.010 & - \\
\hline & within & 0.003 & 14 & 0.000 & - \\
\hline & total & 0.013 & 15 & - & $46.67 a$ \\
\hline \multirow[t]{3}{*}{$72 \mathrm{~h}$} & between & 0.006 & 1 & 0.006 & - \\
\hline & within & 0.001 & 14 & 0.000 & - \\
\hline & total & 0.007 & 15 & - & $72.05 a$ \\
\hline \multicolumn{6}{|c|}{ Stage I I I } \\
\hline \multirow[t]{3}{*}{$24 \mathrm{~h}$} & between & 0.001 & 1 & 0.001 & - \\
\hline & within & 0.003 & 14 & 0.000 & - \\
\hline & total & 0.004 & 15 & - & $7.47 \mathrm{~b}$ \\
\hline \multirow[t]{3}{*}{$72 \mathrm{~h}$} & between & 0.090 & 1 & 0.090 & - \\
\hline & within & 0.004 & 14 & 0.000 & - \\
\hline & total & 0.094 & 15 & - & $262.50 \mathrm{a}$ \\
\hline \multicolumn{6}{|c|}{ Stage IV } \\
\hline \multirow[t]{3}{*}{$24 \mathrm{~h}$} & between & 0.011 & 1 & 0.011 & - \\
\hline & within & 0.006 & 14 & 0.000 & - \\
\hline & total & 0.017 & 15 & - & $21.12 \mathrm{a}$ \\
\hline \multirow[t]{3}{*}{$72 \mathrm{~h}$} & between & 0.014 & 1 & 0.014 & - \\
\hline & within & 0.005 & 14 & 0.000 & - \\
\hline & total & 0.019 & 15 & - & $42.00 a$ \\
\hline
\end{tabular}
a $\quad P<0.01$
b $\quad P<0.05$
c Not significant 
Ammonia excretion rates and $0: \mathrm{N}$ ratios of larval and postlarval lobsters are presented in Figure 3 and Tables 17 and 18, respectively. For all larval and postlarval stages fed oil contaminated Artemia nauplii, ammonia excretion rates were significantly higher and 0:N ratios were significantly lower than control values at the $24 \mathrm{~h}$ sampling period; among the later developmental stages increased $0: \mathrm{N}$ ratios were observed at the $72 \mathrm{~h}$ sampling period, suggesting some adaptation in lipid utilizaton among oil exposed animals(Tables 19 and 20). For larval lobsters exposed to oil contaminated seawater, 0:N ratios were significantly reduced at the $72 \mathrm{~h}$ sampling period and no adaptation was observed among any of the developmental stages.

Body burden evaluations

Gas chromatograms of tail muscle from larval lobsters exposed to oilseawater mixtures are presented in Figure 15 (stage I larvae) and Figure 16 (stage IV larvae). There are little or no differences in the chromatograms for control and oil-exposed stage I larvae (Figs. 15A and 15B) which suggests either limited bioaccumulation or rapid turnover and metabolism of hydrocarbon components. For stage IV larvae (Figs. 16A and 16B), there is some enhancement in the concentration of higher molecular weight compounds ( $C_{18}$ and higher) that may be attributable to oil exposure and may reflect differential turnover rates of various hydrocarbon constituents. Gas chromatograms of tail muscle from larval lobsters fed an oil contaminated food source are presented in Figure 17 (stage I larvae) and Figure 18 (stage IV larvae). The chromatograms of stage I larvae (Figs. $17 \mathrm{~A}$ and $17 \mathrm{~B})$ are virtually identical through the $\mathrm{C}_{18}$ region, however, 


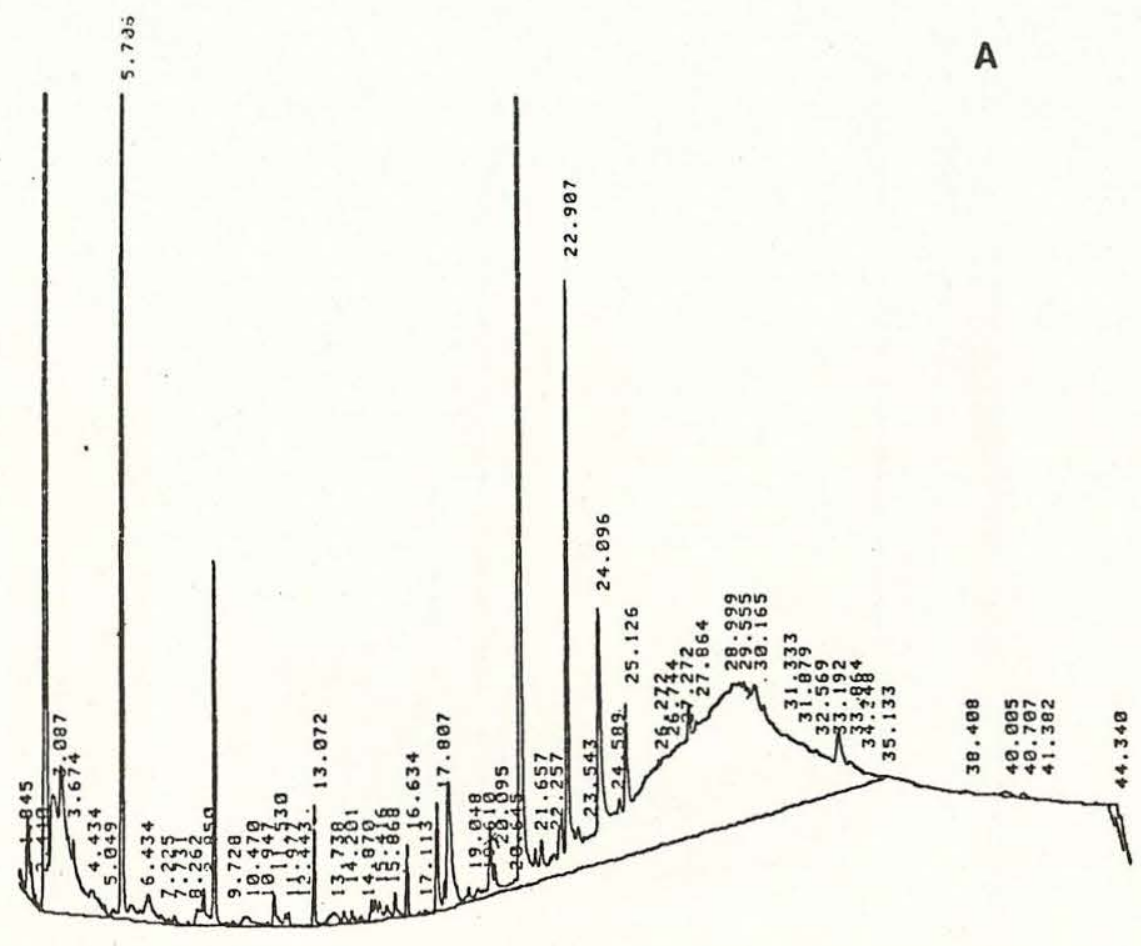

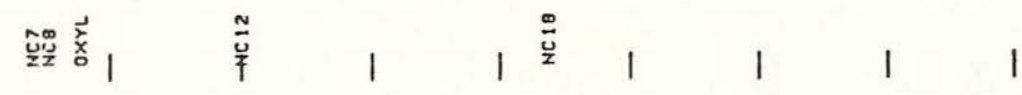

$-\cdots$

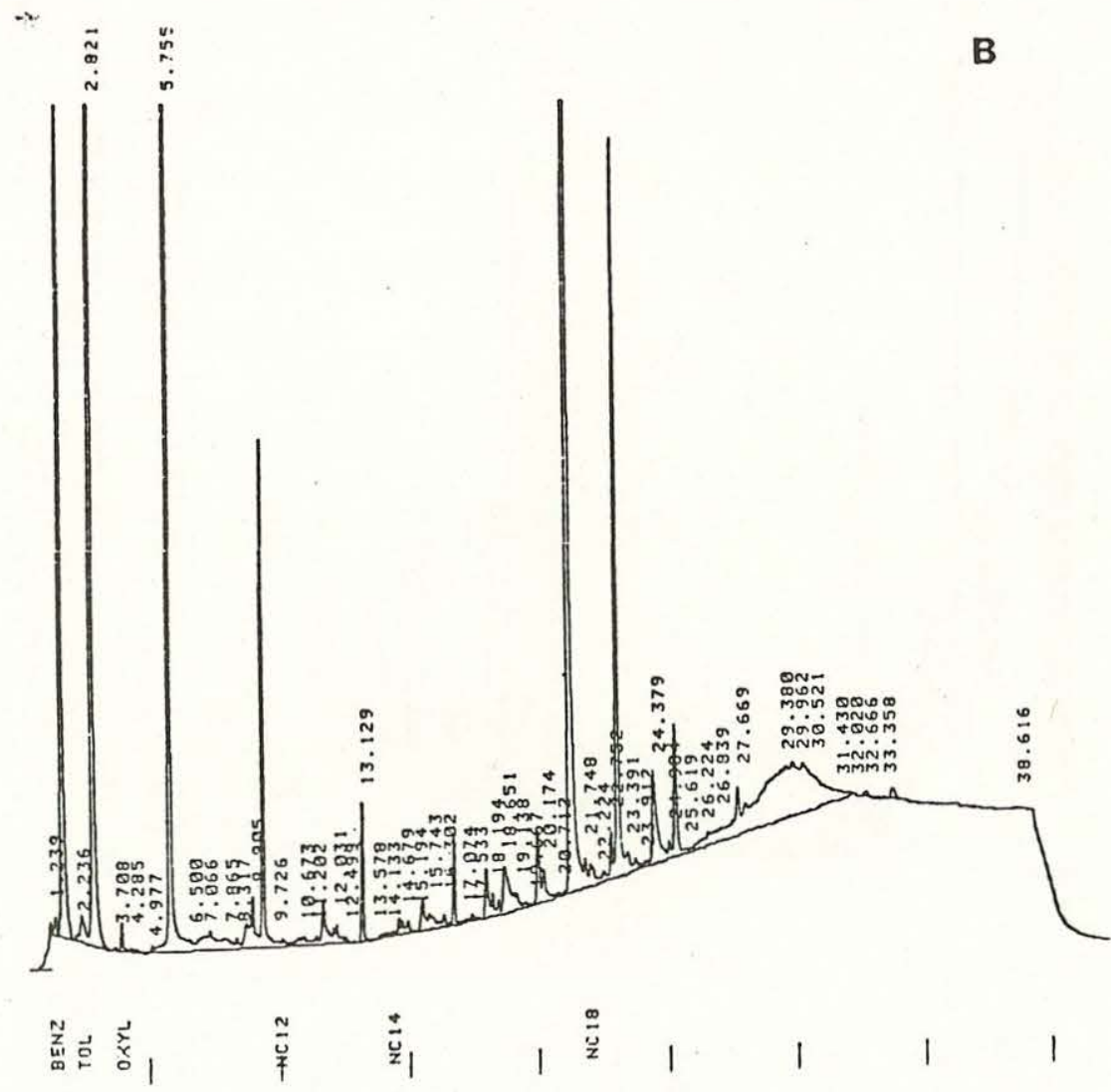

Figure 15. Gas chromatograms of stage I lobster larvae exposed to oil-contaminated seawater; A-control, B-oil-exposed. 

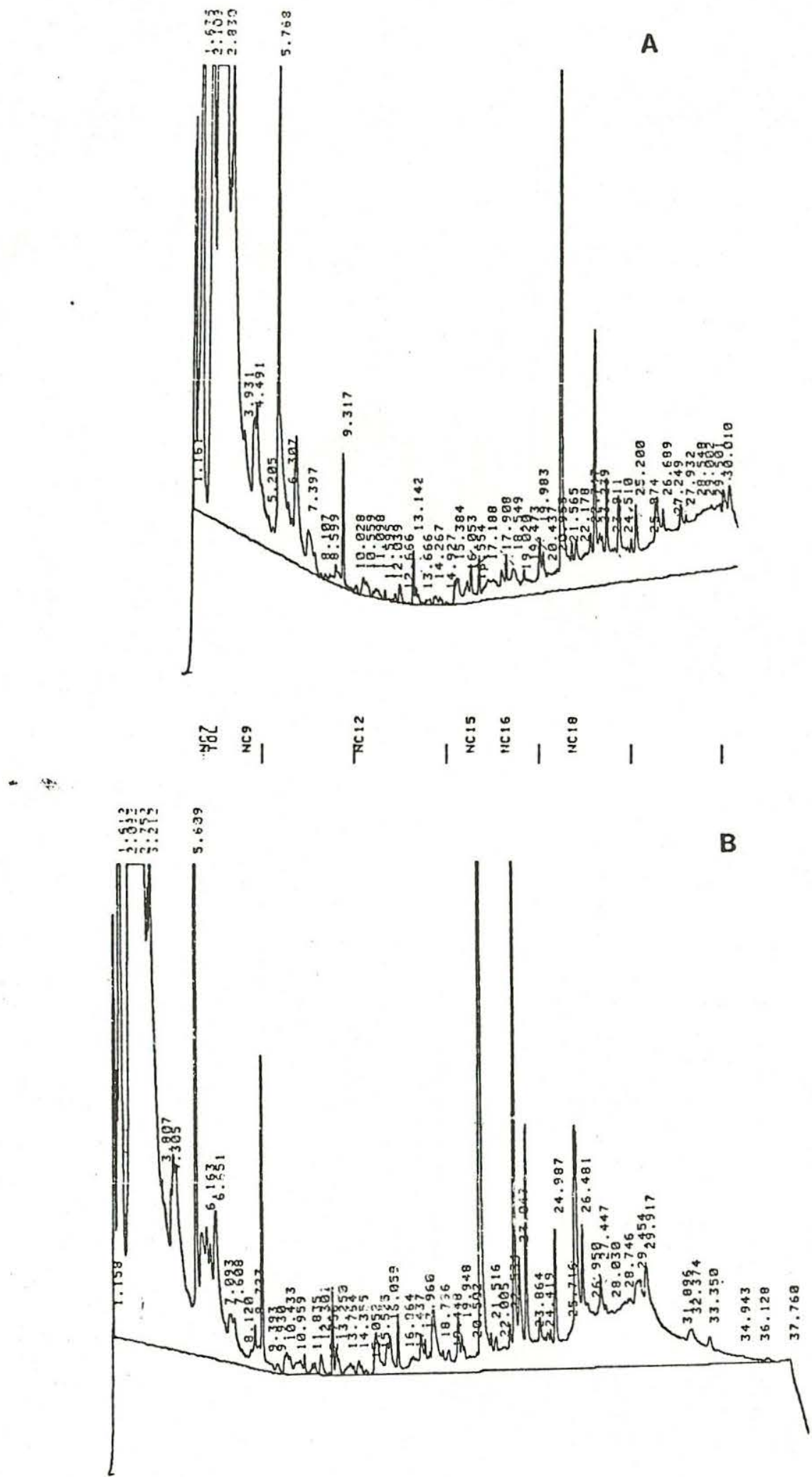

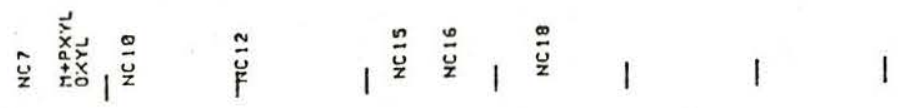

Figure 16. Gas chromatograms of stage IV lobster larvae exposed to oil-contaminated seawater; A-control, B-oil-exposed. 


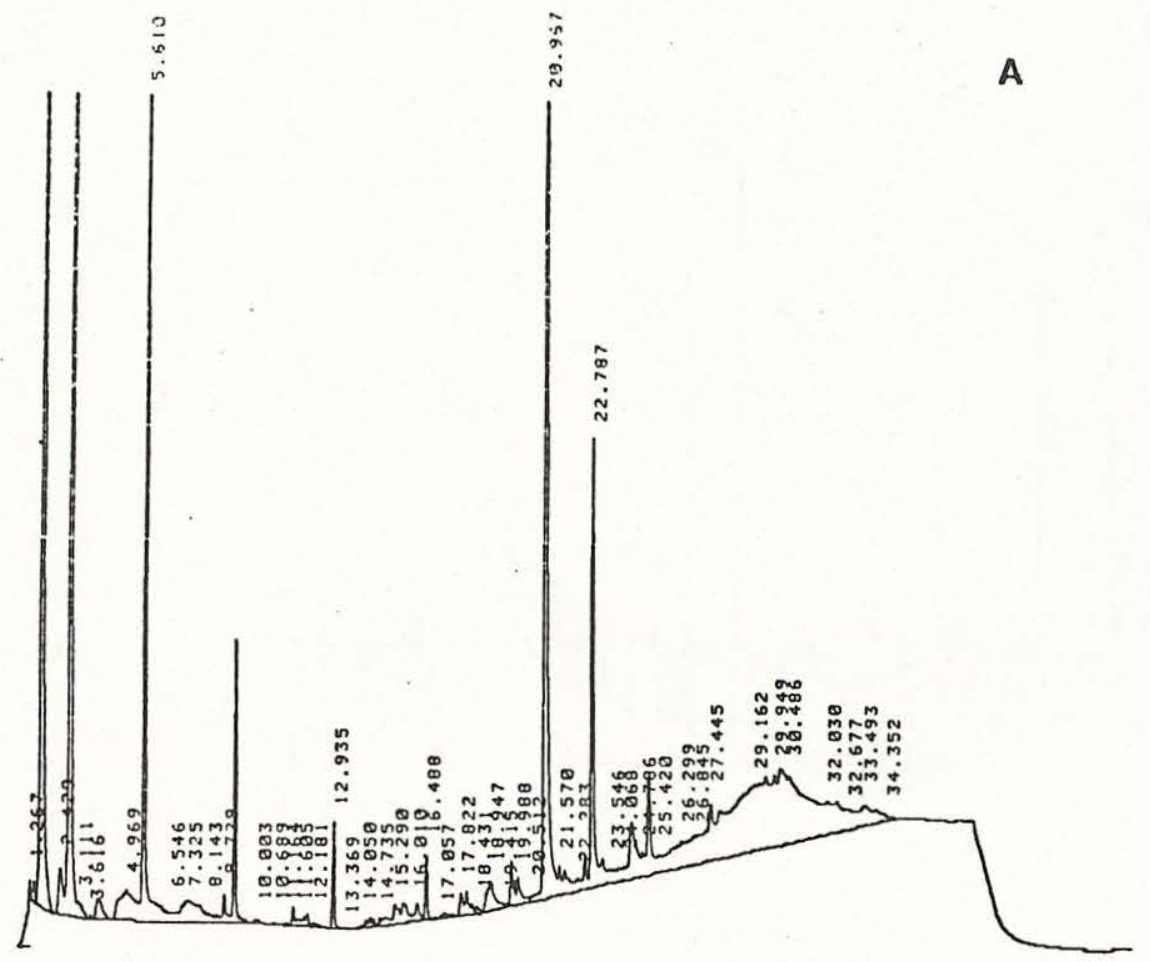

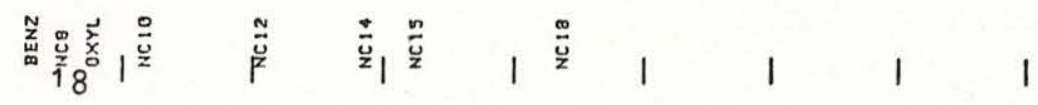

$\rightarrow$

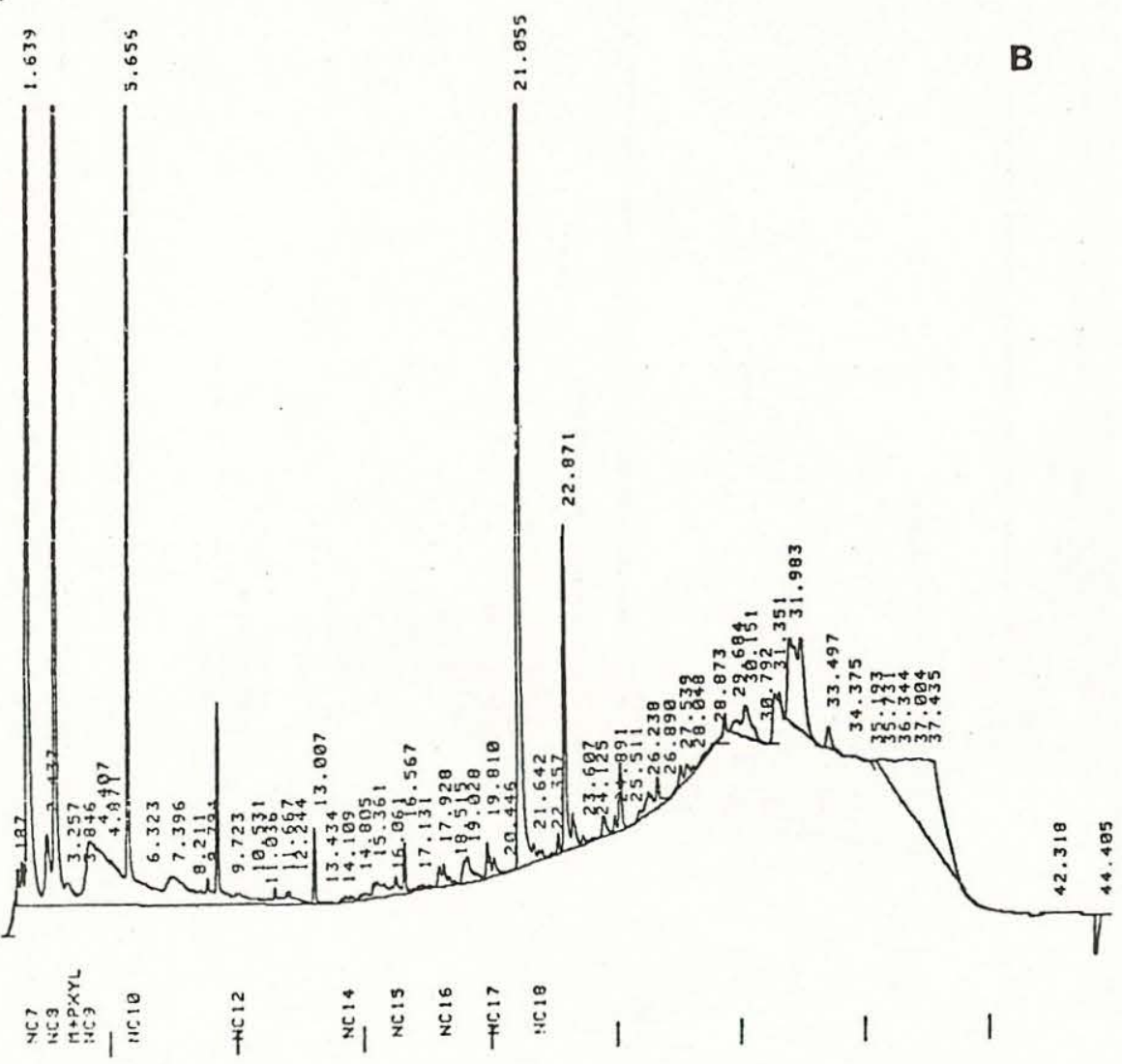

Figure 17. Gas chromatograms of stage I lobster larvae fed an oil-contaminated food source; A-control, B-oil-exposed. 
$-58-$

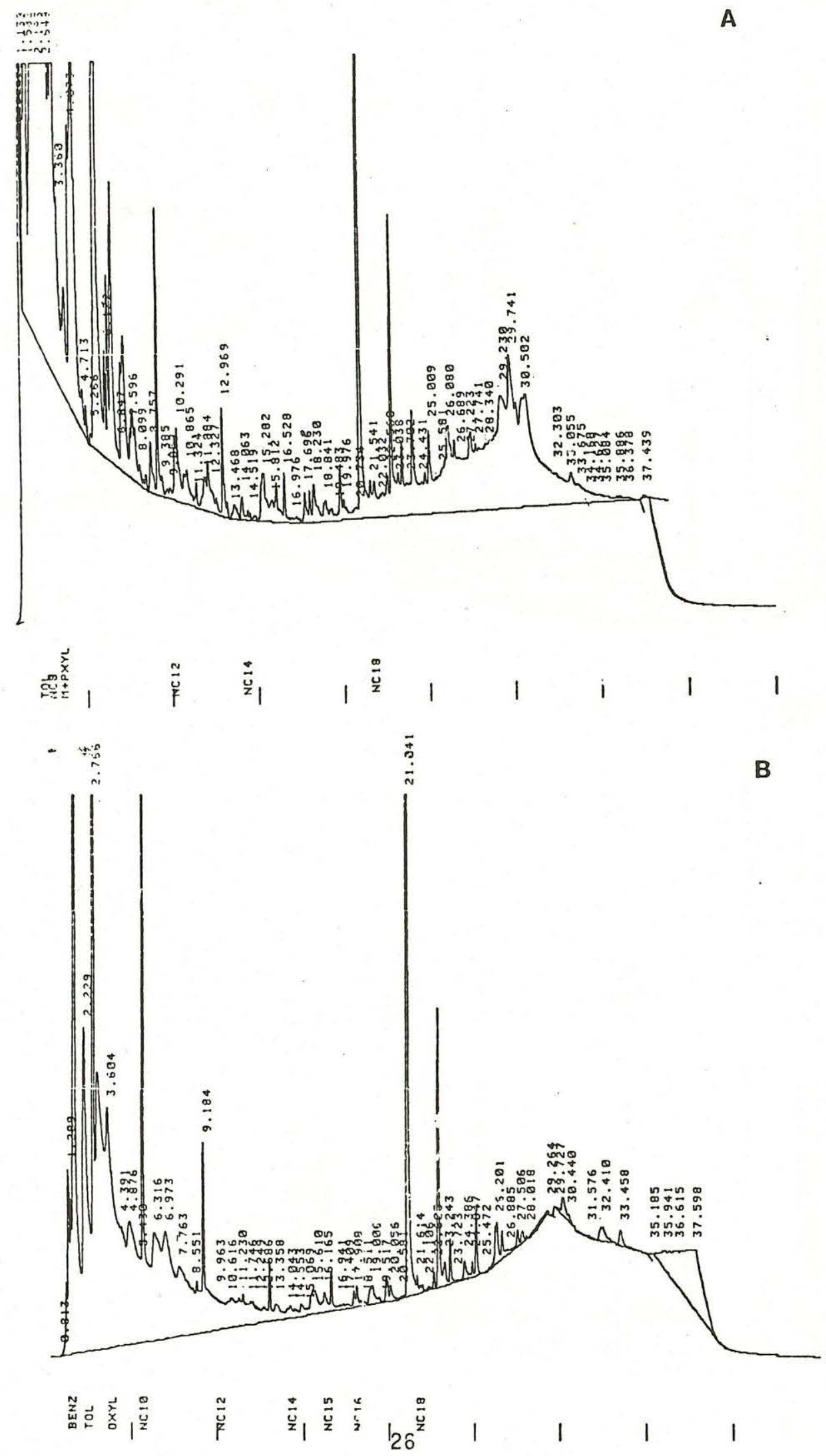

Figure 18. Gas chromatograms of stage IV lobster larvae fed an oilcontaminated food source; A-control, B-oil-exposed. 


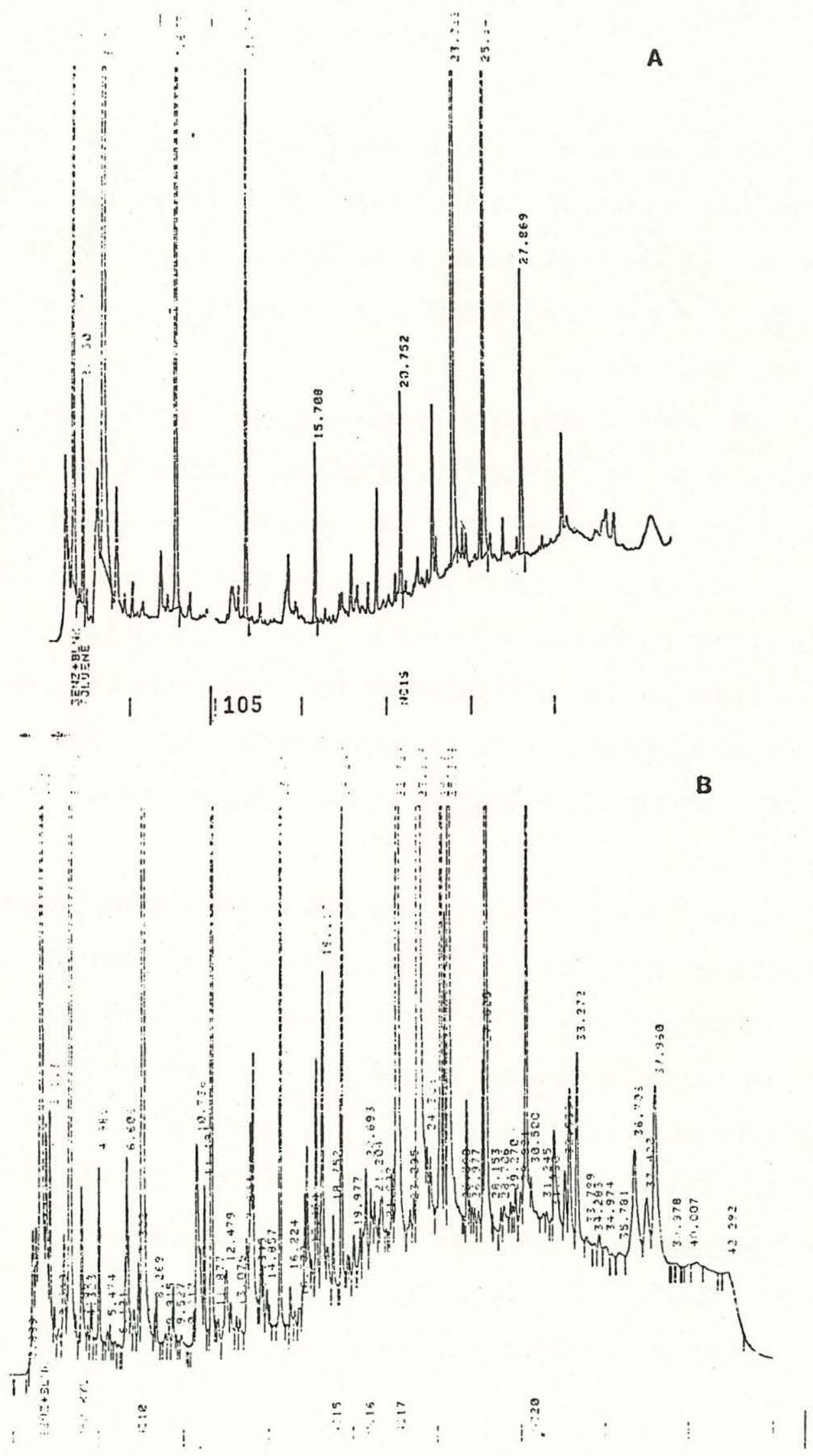

Figure 19. Gas chromatograms of postlarval lobsters exposed to oilcontaminated sediments; A-control, B-oil-exposed. 
increased complexity can be seen with the higher molecular weight compounds from the oil exposed lobsters that may reflect increased bioaccumulation. Similar findings were observed with stage IV larvae (Figs. $18 \mathrm{~A}$ and 18B). Identification of individual compounds will be conducted using GC Mass Spectrometry.

Gas chromatograms of postlarval lobsters exposed to oil contaminated sediments are presented in Figure 19. Significant accumulation and enhancement of both aliphatic and aromatic compounds were observed in the oil-exposed group after the end of the exposure period even though hydrocarbon concentrations of the sediments were negligible. These results suggest that postlarval lobsters may have longer retention times and slower turnover rates of petroleum hydrocarbons than larval stages or that increased bioaccumulation may be seen with longer exposure periods. Discussion

The effects of crude oil and refined oils on the survival, metabolism and energetics of marine crustaceans have recently been investigated (Wells and Sprague, 1976; Edwards, 1978; Laughlin et al., 1978). Other investigators have also observed delayed development of crustaceans as a result of oil exposure (We11s, 1972; Katz, 1973; Linden, 1976; Wells and Sprague, 1976; Caldwel1 et a1., 1977). With chronic exposure of the mud crab Rhithropanopeus harrisij to water soluble fractions of No. 2 fuel 0i1, Laughlin et a1. (1978) found the early zoeal stages to be the most sensitive and larval development was significantly delayed as a result of 
oil exposure. The growth rates of .crab stages and the size distribution and sex ratio of animals at the end of the 6-month exposure period, however, were not significantly different between control and oil-exposed groups.

Edwards (1978) observed changes in respiration rate, growth rate and net carbon turnover in the sand shrimp, Crangon crangon, with chronic exposure to the water soluble components of North Sea Brent Field crude 0i1. Acute exposure (24-48 h) of shrimp to low concentrations ( $5 \% \mathrm{WSF}=$ $1 \mathrm{ppm}$ ) resulted in a reduction in respiration rate but increases and subsequent decreases in respiration rate were observed at higher concentrations ( $10 \%$ WSF $=2 \mathrm{ppm})$. Similar changes in respiratory activity were observed by Lee et a1. (1978) in the shrimp Lucifer faxoni, by Anderson et al. (1974b) in the shrimps Penaeus aztecus and Palaemonetes pugio and by Percy (1977) in the amphipod Onisimus (Boekisimus) affinis. Anderson (1977) suggested that these changes in respiratory activity might be related to a metabolic response to the naphthalene component of water soluble fractions.

Anderson et al. (1980) recently investigated the relationship of mortality and hydrocarbon accumulation of mysids (Neomysis awatschensis) and two species of shrimp (Hippolyte clarkii and Pandalus davae) exposed to Prudhoe Bay crude oil concentrations ranging from 0.36 to $6.35 \mathrm{ppm}$ for periods of 0.5 to 9 days. A "toxicity index" relating exposure time (in days) and $L C_{50}$ concentration (in ppm) was shown to be a useful indicator in predicting the responses of these three crustacean species to oil exposure. Accumulation of di- and triaromatic compounds in the 
tissues of these crustaceans, however, was not cumulative and could not be used to explain cumulative mortality. Anderson et al. (1980) suggested that further analysis of monoaromatic compounds and metabolites might provide some clue to the relationship between mortality and body burden.

Reductions in respiration rates and $0: \mathrm{N}$ ratios of larval and early postlarval stages of the American lobster were observed with exposure to 0.25 ppm South Louisiana crude oil through seawater exposure and ingestion of an oil-contaminated food source. This seawater concentration is within the range measured in surface waters beneath recently deposited oil slicks (Grose and Mattson, 1977; Law, 1978; Mackie et a1., 1978) and because of the abundance of all larval stages in near surface waters (Scarratt, 1964; Lund and Stewart, 1970), would be encountered by larval lobsters immediately following a spill. Accumulation of hydrocarbons in a planktonic food source provides an alternative route of exposure to larval lobsters.

In exposures to oil-seawater mixtures, stage I lobsters were the most sensitive of all larval stages with significant changes in respiration rate occurring within the first $24 \mathrm{~h}$ of the exposure period; significant differences in respiration rates of other larval stages did not become apparent until later $(72 \mathrm{~h})$ in the exposure period. Wells and Sprague (1976) also found Stage I larvae to be the most sensitive to seawater exposure of Venezuelan crude oil, using mortality and swimming activity as response parameters.

For lobsters fed an oil contaminated food source, the later larval stages showed more significant reductions in respiration rate than stage $I$ larvae at the $24 \mathrm{~h}$ sampling period but all stages showed significant 
reductions later in the exposure period. Comparison of larvae exposed to oil-seawater dispersions and those fed an oil contaminated food source indicate a more rapid reduction in respiratory activity in the group fed oil contaminated Artemia nauplii.

The 0:N ratio has been used in several studies (Conover and Corner, 1968; Corner and Cowey, 1968; Bayne and Scullard, 1977; Capuzzo and Lancaster, 1979) as an index of substrate utilization for energy production and has been shown to vary with stage of development, diet and degree of physiological stress. Low $0: \mathrm{N}$ ratios ( 8.0 or below) indicate than an organism is deriving all of its energy supply from protein catabolism; higher values reflect increased dependence on lipid and/or carbohydrate catabolism. The 0:N ratios measured for control lobsters provide an indication that protein catabolism is the principal source of energy for larval lobsters but lipid and or carbohydrate sources are utilized to some extent. The reductions in $0: \mathrm{N}$ ratios of larval lobsters exposed to crude oil through seawater exposure and ingestion of an oil contaminated food source provide an indication of increased dependence on protein catabolism for all larval stages. For larval lobsters exposed to oil-seawater mixtures, the changes in protein and lipid content and the protein: lipid ratio is a further indication that there is a significant shift in both energy storage and utilization as a result of crude oil exposure. Simultaneous increases in the rate of protein catabolism and protein content with reductions in lipid content of oil-exposed larval lobsters suggest that although protein is being metabolized for immediate energy needs, less protein is being utilized for de novo synthesis of lipid reserves. 
A change in energetics as a result of oil exposure may be most crucial as a larval organism approaches metamorphosis and begins to shift its habitat preference from pelagic to benthic; such an impact may affect both larval recruitment and postlarval survival as energy reserves may not be sufficient during this transition period. Stage IV lobsters exposed to $0.25 \mathrm{ppm}$ crude $0 i 1$ showed reductions in the $0: \mathrm{N}$ ratio but successfully molted to the postlarval form. Recovery of lobsters was not immediate upon transfer to clean seawater; reduced metabolic rates but normal 0:N ratios were observed during the post-exposure period. These findings may be an indication that although respiration rates and ammonia excretion rates are reduced relative to control values during the post-exposure period, the normal pattern of energy metabolism and utilization is slowly being restored. The similar protein:lipid ratio of control and oilexposed postlarval lobsters is further evidence for this conclusion. Juvenile lobsters chronically exposed to crude oil-seawater mixtures did not show any alterations in energy utilization. The utilization of lipid as an energy source in the later postlarval stages is significantly reduced in favor of protein catabolism; the lack of response in juvenile lobsters may thus be related to a reduction in importance of lipid utilization and storage.

Postlarval lobsters exposed to contaminated sediments showed significant reductions in respiration rate until sediment concentrations dropped to background levels. Retention of hydrocarbons in the coarse sand substrate was diminished after 15 days and negligible after 30 days in the continuously flowing bioassay system. Accumulation of both aliphatic and 
aromatic components by postlarval lobsters exposed to oil contaminated sediments was significantly enhanced. The rates of hydrocarbon turnover and depuration in these animals warrant further investigation. Wells and Sprague (1976) observed that juvenile lobsters exposed to an oil contaminated gravel-coarse sand substrate exhibited significantly greater burrowing behavior but growth and survival were not affected. Botero (1980) recently reported that newly settled postlarval lobsters showed a preference for a rock-gravel-coarse sand substrate which would facilitate tube building for shelters; selection of this habitat by postlarval lobsters would present only minimal oil contamination problems. The second choice for substrate preference was shown to be a muddy substrate and longer retention of hydrocarbons and microbial degradation of some hydrocarbon components in this substrate could alter the physiological responses of postlarval lobsters.

Anderson et a1. (1974b) suggested that the recovery response of marine crustaceans exposed to oil was related to the release of accumulated hydrocarbons. Lee (1977) discussed the accumulation and turnover of petroleum hydrocarbons in marine crustaceans and Malins (1977) described several mechanisms of bioconversion of hydrocarbons that have been identified in marine organisms. It is apparent that the physiological effects of oil exposure are modified by the ability of the organism to accumulate and detoxify various components of crude and refined oils. Some marine crustaceans possess a mechanism for hydroxylating certain aromatic hydrocarbons (Corner, 1978); this has been recently demonstrated for shrimp and 
crab larvae (Lee, 1975; Sanborn and Malins, 1977). However, the relationship of accumulation and release of hydrocarbons, the metabolic pathways associated with transformation of hydrocarbons, the toxicities of the transformed hydrocarbons, and the interference with protein and lipid metabolism of marine larval crustaceans, especially those as important as the American lobster, need to be further explored. 
Conclusions:

The physiological effects of South Louisiana crude oil on larvae and juveniles of the American lobster Homarus americanus have been investigated in continuous flow bioassay systems. Disruption in the energetics of larval development has been observed and correlated with a shift in the normal patterns of lipid utilization and storage in larval lobsters. Hydrocarbon turnover appears to be rapid and little accumulation, except of the higher molecular weight constituents, is observed. Recovery of larval and early postlarval stages is not immediate upon transfer to uncontaminated seawater and the normal pattern of energy storage and utilization is only slowly restored.

Postlarval lobsters are less sensitive to crude oil-seawater mixtures than the larval stages and no disruption in energetics has been observed. Reductions in respiratory activity and bioaccumulation of both aliphatic and aromatic compounds, however, have been observed in postlarval lobsters exposed to oil contaminated sediments. This suggests that postlarval lobsters have longer retention times and slower turnover rates of petroleum hydrocarbons than the larval stages and persistence of petroleum hydrocarbons in sediments may present a chronic contamination problem to benthic stages of the American lobster. 
Acknowledgements:

The author wishes to thank Mr. John Hughes of the Massachusetts State Lobster Hatchery and Mr. George Hampson of the Woods Hole Oceanographic Institution for providing us with egg-bearing lobsters; Mr. Bruce Lancaster, Mr. Terence Hammar and Mr. Rodman Taylor of WHOI and Mr. Francisco Tomei of MIT for technical assistance; and Dr. John Farrington and Dr. Jean Whelan of WHOI for advice on chemical analyses. 
Literature Cited:

Anderson, J.W., 1977. Responses to sublethal levels of petroleum hydrocarbons: are they sensitive indicators and do they correlate with tissue contamination? In: D.A. Wolfe (ed.), Fate and Effects of Petroleum Hydrocarbons in Marine Organisms and Ecosystems. Pergamon Press, New York, pp. 95-114.

Anderson, J.W., J.M. Neff, B.A. Cox, H.E. Tatem, and G.M. Hightower, 1974a. Characteristics of dispersions and water-soluble extracts of crude and refined oils and their toxicity to estuarine crustaceans and fish. Mar. Biol. 27: 75-88.

Anderson, J.W., J.M. Neff, B.A. Cox, H.E. Tatem, and G.M. Hightower, 1974b. The effects of oil on estuarine animals: toxicity, uptake and depuration, respiration. In: F.J. Vernberg and W.B. Vernberg (eds.), Pollution and Physiology of Marine Organisms. Academic Press, New York, pp. 285-310.

Anderson, J.W., S.L. Kiesser, and J.W. Blaylock, 1980. The cumulative effect of petroleum hydrocarbons on marine crustaceans during constant exposure. Rapp. P.v. Réun. Cons. int. Explor. Mer 179: 62-70. Bayne, B.L. and C. Scullard, 1977. Rates of nitrogen excretion by species of Mytilus (Bivalvia:Mollusca). J. mar. biol. Ass. U.K. 57: 355-369.

Botero, L., 1980. Substrate selection and settling behavior of larval lobsters, Homarus americanus Milne Edwards. M.A. Thesis, Boston University, Boston, MA. 52pp. 
Caldwell, R.S., E.M. Calderone, and M.H. Mallon, 1977. Effects of seawater-soluble fraction of Cook Inlet crude oil and its major aromatic components on larval stages of the Dungeness crab, Cancer magister Dana. In: D.A. Wolfe (ed.), Fate and Effects of Petroleum Hydrocarbons in Marine Organisms and Ecosystems. Pergamon Press, New York, pp. 210-220.

Capuzzo, J.M. and B.A. Lancaster, 1979. Some physiological and biochemical considerations of larval development in the American lobster, Homarus americanus Milne Edwards. J. exp. mar. Biol. Ecol. 40: 53-62. Capuzzo, J.M., S.A. Lawrence and J.A. Davidson, 1976. Combined toxicity of free chlorine, chloramine and temperature to stage I larvae of the American lobster Homarus americanus. Water Research 10: 1093-1099. Cobb, S.J., 1976. The American lobster: the biology of Homarus americanus. University of Rhode Island Sea Grant Technical Report, Kingston, R.I., U.S.A., 32 pp.

Conover, R.J. and E.D.S. Corner, 1968. Respiration and nitrogen excretion by some marine zooplankton in relation to their life cycles. J. mar. biol. Ass. U.K. 48: 49-75.

Corner, E.D.S., 1978. Pollution studies with marine plankton. Part 1. Petroleum hydrocarbons and related compounds. Adv. mar. Biol. 15: 289-380.

Corner, E.D.S. and C.B. Cowey, 1968. Biochemical studies on the production of marine zooplankton. Biol. Rev. 43: 393-426. 
Edwards, R.R.C., 1978. Effects of water-soluble oil fractions on metabolism, growth and carbon budget of the shrimp Crangon crangon. Mar. Biol. 46: 259-265.

Farrington, J.W., 1976. Petroleum hydrocarbons. In: E. Goldberg (ed.), Strategies for Marine Pollution Monitoring. Wiley Interscience, New York. pp. 3-34.

Farrington, J.M. and A.C. Davis, 1978. Sumary of analytical methodology applied to "Mussel Watch". Mussel and oyster samples at Woods Hole Oceanographic Institution (1975-1978) to determine PCB's, DDT family, and hydrocarbons. Unpublished manuscript, WHOI, Woods Hole, MA.

Forns, J.M., 1976. Initial evaluations of larval lobsters (Homarus americanus) to South Louisiana crude oil. Final report to American Petroleum Institute, Washington, D.C. $26 \mathrm{pp}$.

Forns, J.M., 1976-78. Crude oil effects to developmental stages of the American lobster. Monthly reports to Bureau of Land Management, Washington, D.C.

Forns, J.M., 1977. The effects of crude oil on larvae of lobster Homarus americanus. Proceedings, $0 i 1$ Spill Conference (Prevention, Behavior, Contro1, Cleanup). EPA/API/USCG. pp. 569-573.

Grose, P.L. and J.S. Mattson, 1977. The Argo Merchant oil spil1, a pre1 iminary scientific report. U.S. Dept. of Commerce, NOAA, Boulder, Colorado.

Herrick, F.H., 1896. The American lobster: a study of its habits and development. Bu11. U.S. Fish. Comm. 15: 1-252. 
Herrick, F.H., 1911. Natural history of the American lobster. Bul1. U.S. Bur. Fish. 29: 149-408.

Hughes, J.T. and G.C. Matthiessen, 1962. Observations on the biology of the American lobster, Homarus americanus. Limnol. Oceanogr. 7: 414-421.

Hughes, J.T., R.A. Shleser and G. Tchobanoglous, 1974. A rearing tank for lobster larvae and other aquatic species. Prog. Fish Cult. 36: $129-132$.

Johnson, P.T., 1980. Histology of the blue crab, Callinectes sapidus. A model for the Decapoda. Praeger Publishers, New York, 440 pp.

Katz, L.M., 1973. The effects of water-soluble fractions of crude oil on larvae of the decapod crustacean Neopanope texana (Say). Environ. Pollut. 5: 199-204.

Laughlin, R.B., Jr., L.G.L. Young, and J.M. Neff, 1978. A long-term study of the effects of water-soluble fractions of No. 2 fuel oil on the survival, development rate, and growth of the mud crab Rhithropanopeus harrisii. Mar. Biol. 47: 87-95.

Law, R.J., 1978. Petroleum hydrocarbon analyses conducted following the wreck of the supertanker Amoco Cadiz. Mar. Pollut. Bul1. 9: 293-296. Lee, R.F., 1975. Fate of petroleum hydrocarbons in marine zooplankton. In: Proc. Conf. on Prevention and Control of $0 i 1$ Pollution. American Petroleum Institute, Washington, D.C. pp. 549-553.

Lee, R.F., 1977. Accumulation and turnover of petroleum hydrocarbons in marine organisms. In: D.A. Wolfe (ed.), Fate and Effects of Petroluem Hydrocarbons in Marine Organisms and Ecosystems. Pergamon Press, New York, pp. 60-70. 
Lee, W.Y., K. Winters, and J.A.C. Nicol, 1978. The biological effects of the water-soluble fractions of a No. 2 fuel $0 i 1$ on the planktonic shrimp, Lucifer faxoni. Environ. Pollut. 15: 167-183.

Linden, 0., 1976. Effects of $0 i 1$ on the amphipod Gammarus oceanicus. Environ. Pollut. 10: 239-245.

Lund, W.A. and L.L. Stewart, 1970. Abundance and distribution of larval lobsters, Homarus americanus, off the coast of southern New England. Proc. Nat'1. Shel1fish Assn. 60: 40-49.

Mackie, P.R., R. Hardy, E.I. Butler, P.M. Holligan, and M.F. Spooner, 1978. Early samples of oil in water and some analyses of zooplankton. Mar. Pollut. Bull. 9: 296-297.

Malins, D.C., 1977. Biotransformation of petroleum hydrocarbons in marine organisms indigenous to the Arctic and Subarctic. In: D.A. Wolfe (ed.), Fate and Effects of Petroleum Hydrocarbons in Marine Organisms and Ecosystems. Pergamon Press, New York pp. 47-59.

Marsh, J.B. and D.B. Weinstein, 1966. Simple charring method for determination of 1ipids. J. Lipid Res. 7: 574-576.

Neff, J.M. and J.W. Anderson, 1975. An ultraviolet spectrophotometric method for the detemination of naphthalene and alkylnaphthalenes in the tissues of oil-contaminated marine animals. Bul1. Env. Contam. Toxicol. 14: 122-128.

Percy, J.A., 1977. Effects of dispersed crude oil upon the respiratory metabolism of an Arctic marine amphipod Onisimus (Boekisimus) affinis. In: D.A. Wolfe (ed.), Fate and Effects of Petroleum Hydrocarbons in Marine Organisms and Ecosystems. Pergamon Press, New York, pp. $192-200$ 
Raymont, J.E.G., J. Austin and E. Linford, 1964. Biochemical studies on marine zooplankton. I. The biochemical composition of Neomysis integer. J. Cons. perm. int. Explor. Mer 28: 354-363.

Sanborn, H.R. and D.C. Malins, 1977. Toxicity and metabolism of naphthalene: a study with marine larval invertebrates. Proc. Soc. Exp. Biol. Med. 154: 151-155.

Scarratt, D.J.,1964. Abundance and distribution of lobster larvae (Homarus americanus) in Northumberland Strait. J. Fish. Res. Bd. Canada 21: 661-680.

Sokal, R.R. and F.J. Rohlf, 1969. Biometry. W.H. Freeman and Co., San Francisco, $776 \mathrm{pp}$.

Solorzano, L., 1969. Determination of ammonia in natural waters by the phenolhypochlorite method. Limnol. Oceanogr. 14: 799-801. Wells, P.G., 1972. Influence of Venezuelan crude oil on lobster larvae. Mar. Pollut. Bul1. 3: 105-106.

Wells, P.G. and J.B. Sprague, 1976. Effects of crude $0 i 1$ on American lobster ( Bd. Canada 33: 1604-1614. 
$-75-$

APPENDIX 


\author{
FINAL SUMMARIZATION \\ (Including July Progress Report) \\ "Crude Oil Effects to Developmental Stages \\ of American Lobsters"
}
Submitted to: Bureau of Land Management
Department of the Interior
18 th \& C Streets, N.W.
Washington, D.C. 20240
Submitted by: Westinghouse Ocean Research Laboratory Oceanic Division
P.0. Box 1488
Annapolis, Maryland 21404

Contract Number: AA550-CT7-24

Date: August 1978 
EXECUTIVE SUMMARY

This report constitutes the final documentation of the work performed for the Bureau of Land Management by the Westinghouse Ocean Research Laboratory on a project to evaluate the effects to planktonic larval lobsters by exposures to various concentrations of South Louisiana crude oil in seawater. Most of the biological investigations for this project took place at the Massachusetts State lobster Hatchery on Martha's Vineyard. Analytical chemistry of samples and histological examinations of tested organisms were conducted at the Westinghouse Laboratory in Annapolis, Maryland.

As originally proposed, this project was scheduled to last for thirty-six months from March of 1977 through February of 1980 and incorporate three primary task objectives. These experimental tasks included:

A. the observation and evaluation of grow-out conditions for post-fourth stage lobsters which were subjected, as larvae, to various concentrations of crude oil.

B. the experimental testing of the hatch success and larval development of eggbearing lobsters subjected to flow-through exposures of crude oil in seawater.

C. the assessment of effects to planktonic lobster larvae exposed to a variety of conditions of flow-through exposures of crude oil in seawater.

Based on the amended proposal of January 1977, task A (AGRO) is continuing and $21 \%$ of the original stock culture of test larvae from the 1976 year class are growing in the flow-through system at the hatchery. Most of the mortalities to these animals are the result of a bacteria discovered in the late summer of 1977. Comparison of the growth and development of the total original stock culture does not indicate any significant differences between the survival of control or oil-exposed animals. 
Two of the four proposed tasks with egg-bearing lobsters (BEGG) were undertaken between April 1977 and May 1978. One test with developed eggs (golden eggers) and one with recently extruded eggs (black eggers) were completed. From the "golden eggers" oil-exposure test, we recorded a $7 \%$ reduction in the hatch success by oil-exposed egg lobsters. Based on theoretical fecundities of each egg lobster tested, the success of larvae hatched was $65 \%$ for controls and $58 \%$ for oiled eggers. Unhatched eggs for control lobsters were $0.9 \%$ and $1.4 \%$ for oil-exposed lobsters. Larval development to fourth stage indicated an insignificant $1.2 \%$ difference between fry from controls and oil-exposed egg lobsters.

Results of the "black egg lobster" tests showed an $18 \%$ lower hatch success by the oil-exposed egg lobsters. This difference was significant, and although egg develppment times for both control and oil-exposed lobsters were similar, the average egg hatching periods were six days longer for oil-exposed eggers. This prolonged release time indicated that the oilexposed eggers had great difficulty in the hatching process. Also, the numbers of unhatched eggs from oil-exposed eggers was significantly higher than controls. (greater than $30 \%$ of the average controls).

Four flow-through toxicity tests (CTOX) were accomplished during natural hatching periods for egg lobsters in the early summer months of 1977 and 1978. Twenty-four hour, first stage lobster larvae were tested in flow-through crude oil in seawater emulsions with concentrations ranging from 0.1 through $1.5 \mathrm{ppm}$. During one test in 1977,10 and $50 \mathrm{ppm}$ oil/seawater concentrations, using only the water soluble fractions, were tested in the same flow-through assay system.

Using mass culture systems (1000 larvae per test concentration), continuous flow-through assay experiments were conducted for the entire period of larval development (approximately 17 days). Based on the results of the four tests conducted, we observed a significant mortality of developing larvae in the water soluble fraction of the 10 and 50ppm oil and seawater tests. From the results of the oil emulsion tests there appears to be a significant mortality threshold (greater than 20\%) for lobster larvae between the $0.5 \mathrm{ppm}$ and $1.0 \mathrm{ppm}$ oil in seawater concentrations. 
The time for larval development was consistently longer for larvae in the 1.0 and $1.5 \mathrm{ppm}$ test concentrations and the average sizes for larvae exposed to the $1.0 \mathrm{ppm}$ oil concentration were $25 \%$ smaller than controls and lower oil concentrations.

In early August, the surviving AGRO lobsters will be transferred to the Environmental Systems Laboratory of the Woods Hole Oceanographic Institution (WHOI). A11 BLM funded equipment and materials purchased during the Westinghouse contract period will be transferred to WHOI for continuation of the project. In addition, Westinghouse furnished equipment will be moved to WHOI for use in the performance of the remainder of the lobster oil toxicity investigations. 


\section{INTRODUCTION}

The inadequacy of estimating environmental consequences on larval plankton communities from petroleum hydrocarbons has been cited as a means of slowing or stopping development of outer continental shelf resources within the Mid-Atlantic Bight. Although there is little disagreement concerning this lack of background or experimental information, recent developments focusing on energy shortages appear to be heavily influencing the need for more sources of petroleum, especially in the Northeastern United States. Data compiled by Kash (1973) estimates world oil pollution by source (Table 1 ).

Interest in oil and gas exploration off the northeastern and midAtlantic coasts of the United States has raised several questions concerning potentially adverse ecological impacts to a presently overexploited fishery. Evidence of this can be seen in the recent lobster statistics (NOAA, 1977). A few selected areas of these historically rich fishing grounds extending from Nova Scotia to Cape Hatteras have been identified for possible petroleum development. While it has been reported (NAS 1975) that $1.3 \%$ of all oil input to the sea results from offshore oil drilling operations and that approximately 5\% (Ketchum, 1974) of all petroleum inputs to the marine enxironment come from accidental tanker spills, the majority of these oil releases (86.1\%) (NAS, 1975) occur within the nearshore ( $<50$ miles) marine environment. Depending on the manipulation of these statistics, the potential for deleterious impact to marine organisms must be considered serious.

Several studies have reported effects of petroleum hydrocarbons upon marine plankton. After Torrey Canyon, Smith (1968) observed toxic effects to copepods Calanus finmarchicus, Acartia clausi and oyster larvae by the dispersants used to break up the spill. Corner et al. (1968) and Portmann (1973) indicated toxicity to pelagic marine forms was due to soluble fractions of seawater oil emulsions. Studying the brown shrimp Crangon crangon Portmann demonstrated 48-hour $\mathrm{LC}_{50}$ toxicities ranging from 3.3 to $>3000$ ppm with larvae three to five times more sensitive than adults. 


\begin{tabular}{|c|c|c|}
\hline SOURCE & $\begin{array}{l}\text { VOLUME } \\
(1,000 \text { barrels })\end{array}$ & PERCENT \\
\hline Marine operations & 16,100 & 46.1 \\
\hline Tankers & 9,710 & 27.7 \\
\hline Tank barges & 490 & 1.4 \\
\hline All other vessels & 5,950 & 17.0 \\
\hline Non-marine operations & 17,400 & 49.9 \\
\hline Offshore oil and gas operations & 1,400 & 4.0 \\
\hline Total direct pollution & 34,900 & 100.0 \\
\hline
\end{tabular}


Mironov (1973) found that oil concentrations of $0.001 \mathrm{ml} / 1$ accelerated mortalities of Acartia clausi and Paracalanus parvus. However, the general reduction in survival was less than $20 \%$. Kühnhold (1973), investigating cod Cadus morrhua, herring Clupea harengus, and plaice Pleuronectes platessa eggs found that Venezuelan crude oil caused $40 \%$ higher mortalities than controls; Iranian crude was $30 \%$ aböve controls and Libyan crude was relatively nontoxic at $10^{-4} \mathrm{ppm}$ for as long as 100 hours of exposure. We1ls and Sprague (1976) reported toxicity to first stage larval lobsters (Homarus americanus) to be $0.14 \mathrm{ppm}$ based on static assays with Venezuelan crude oil.

Though few definitive conclusions can be drawn from most of the literature, it seems apparent that certain generalizations can be made regarding plankton and oil. (1) Crude oil seems less toxic to zooplankton than dispersants used for clean up, (2) not all crude oils give the same effect on plankton, (3) though local catastrophic effects may be realized from major spills, zooplankton populations seem to recover within one season cycle, provided there is sufficient flushing, (4) relative size of the planktonic organisms seems to be related to resistance, and (5) larval forms of the plankton community are more sensitive to petroleum perturbations than the mature adult forms.

Typically, laboratory studies with pelagic marine organisms involve mixing oil and seawater gently, separating the phases and using only the water soluble fraction (WSF) in seawater for toxicity testing (Anderson, 1977). While this procedure allows for a simplified and quantitative delivery of WSF petroleum hydrocarbons, it does not realistically account for the volatilization of aromatics in the open ocean environment or the variety of hydrocarbon equilibria which probably occur when crude oil is spread over seawater. As a result, WSF oil toxicity studies tend to emphasize disproportionate concentrations of aromatic fractions which may not normally occur from crude oil spills in the ocean.

Another difficulty in testing oil effects to holo- and meroplanktonic forms lies in the nature of statistically designed bioassays which often pay little attention to the specific behavioral requirements of the organisms tested. Orbital motions, feeding migrations, and hydraulic agitation play important roles in the successful development of planktonic forms. Most 
static bioassays measure acute toxicity which is based solely on mortality recorded for a relatively short period of time. Thus, control organisms may survive in the sense that motion and heart beat can be observed, but their development and ultimate mortality may only be delayed slightly beyond that of the exposure test organisms. In addition, certain non-lethal effects may make the planktonic forms more vulnerable to predation in the open ocean environment.

The successful propagation of lobsters is dependent upon several critical developments (Hughes and Matheissen, 1962). The female lobster can only mate during relatively short periods of time (approximately 48 hours) following a molt while the new shell is still soft. After a female's fertilization and egg development, hatched first stage larvae "float" to the sea surface where four developmental metamorphoses take place before they return to a benthic existence. During this 15-50 day period, planktonic larvae are members of the neuston by day and near sea surface at night. They are extremely vivacious feeders and often exhibit significant cannibalism within their patchy swarms. Recent statistics indicate that for an average sized "ripe" female containing about 35,000 eggs, 40 must survive to legal harvest size for two to reach and complete sexual maturity.

Selection of lobster larvae for our experiments was based on three considerations. First, lobsters spend the most sensitive stage of development within the planktonic community. From the hatched egg through the fourth stage of development, larval lobsters are members of the near surface neuston. It is within the upper $25 \mathrm{~cm}$ of sea surface that young lobsters develop (Herrick, 1896). Hence, any increases in the frequency of a toxic fraction of oil in the sea surface could have immediate and delayed, but harmful, results on vast populations of lobsters. The second reason for selection of the lobster is that the developing forms, from post-larval stages through maturity, take approximately 5 to 7 years. During this time the organisms take up a benthic existence scavenging food and seeking shelter in protected areas. Petroleum residues associated with offshore drilling operations, structures and pipelines, could contaminate these organisms, making them unfit for human consumption. Finally, the third 
reason for selecting the lobster for study is that it represents a significant economic asset to the northeastern U.S. economy as a food resource. The approach taken for these investigations included the design of experiments to accomodate the lobsters' natural behavior, growth and deve1opment requirements, utilization of emulsions made up of whole crude oil in seawater for testing biological effects and multiple reproduction of experiments to verify the results of individual tests. The project was set up to conduct three concurrent experimental tasks which combined the coincidence of natural seasonality with artificial acceleration of lobster development. To accomplish this a heated flow-through seawater system was installed at the Massachusetts State Lobster Hatchery and all biological experimentation took place at the hatchery.

The three tasks undertaken for this project included:
A. measurement of the growth and development of post-fourth stage lobsters which had previously been subjected to crude oil exposures as larvae.
B. evaluation of oil effects on the hatch success for fertilized egg- bearing lobsters and their subse- quent larval development.
C. determination and identification of the toxic effects of crude oil to planktonic lobster larvae by conducting a variety of flow- through assay experiments.

During the past year, from April 1977 through July 1978, parts of all three tasks have been completed and the continuation of this project is expected to be undertaken at the Woods Hole Oceanographic Institution. The purpose of this report is to describe the methods for the investigations undertaken and to summarize the results of the experiments completed thus far. The reader is referred to the original proposal and to the monthly progress reports for additional details and information concerning this project. 


\section{EXPERIMENTAL METHODOLOGY}

The purpose of this report section is to define and describe the techniques and methods which were used to carry out the three project tasks. Further detail and elaboration is available in the monthly progress reports. Because the different task experiments were conducted concurrently, hydrocarbon documentations were catalogued by task and type of analysis, as well as by sequential serial number. Extraction and analytical procedures for the IR/seawater samples are given in Table 2 and GC/seawater procedures are given in Table 3. Instrument linearity for the Beckman 20A dual beam scanning IR is shown in Figure 1. and the oil/seawater standard series is given in Figure 2.

TASK A: AGRO

Growth and development studies of the 1976 year class lobsters has been accomplished thus far by development of a temperature controlled flow-through seawater system (Figure 3). This flow-through system is broken down into two seawater loops and a fresh water heating loop. The first seawater sub-system is an ultraviolet and heat exchanger loop with bypasses for each component sub-system. This loop is serviced by a $17 \mathrm{gpm}$ 1ift pump through 3/4" PVC piping to the glass Aquafine UV filter and impervious graphite 3 pass, 9 tube shell-in-tube heat exchanger. Heated exchanged seawater from the freshwater loop which returns to the primary reservoir is lifted by a $35 \mathrm{gpm}$ pump to a 475 gallon head tank on the second floor of the hatchery (approximately 15' above the primary reservoir). From the head tank heated seawater passes through a network of 2" PVC pipes to the various lobster culture tanks within the AGRO system. Drain water from these tanks is filtered and delivered to the primary reservoir for partial recirculation. By adjusting the flow rate of ambient temperature seawater, the entire seawater system can be turned over once every 20 hours.

Each of the 176 year class lobsters in the AGRO system, as well as the '77 year class lobsters, are kept in seperate flow-through compartments 
Table 2.

SKETCH SHEET

WESTINGHOUEE FORM 244AD

WESTINGHOUSE ELECTRIC CORPORATION

PROGRAM: BLM- Lobster Research Program

IR Procedure for hydrocarbon analysis based on procedure of Brown, et. al. (1975)

Weigh sample

Obtain 1.0 liter seawater sample with

- teflon tube by siphoning into a "clean"

Separatory funnel.

Extract sample with $35 \mathrm{ml}$. BEJ $\mathrm{CCl}_{4}$

- [2 extractions, $20 \mathrm{ml}$. $+15 \mathrm{ml}$.]

Include froth with $\mathrm{CCl}_{4}$ sample extract.

- Label and store in freezer at $-4^{\circ} \mathrm{C}$. [Transport frozen]

Bring sample to room temperature and separate froth by removing upper $3 \mathrm{ml}$.

- with "clean" pasteur pipet; pass this fraction of sample through sodium sulfate column with $\mathrm{N}_{2}$ gas. *1 Add to sample.

- Run initial $I R$ on sample fraction and rinse Calculate extractable organics from $\%$ of total volume used in $I R$ vs wt. of total sample into original sample vial.

- Concentrate sample and perform column chromatography according to procedure.

- Store final sample volume in permanent

Calculate final sample volume vials, label and determine sample wt.

- Run sample on $I R$ and determine total

Calculate hydrocarbon content hydrocarbons.

based on relative hydrocarbons

from control samples.

[Include blank in determination of final values]

- Store sample in permanent vials.

Note 1 Pack $5 \mathrm{ml}$. pipet with about $4 \mathrm{ml}$. sodium sulfate; rinse with $5 \mathrm{ml} . \mathrm{CCl}_{4}$. 
Table 3

SKETCH SHEET

WESTINQNOUEE FORM 244DD

WESTINGHOUSE ELECTRIC CORPORATION

BLM - LOBSTER RESEARCH PROGRAM

Hydrocarbon Analyses: GC procedures for seawater samples

- Collect 1. liter seawater samples from test systems with teflon tubing into precleaned glass separatory funnel.

- Acidify sample to $\mathrm{pH}<2$ with $\mathrm{HCL}$.

- Extract samples twice with BEJ $\mathrm{CHCl}_{3}$. [25 ml \& $\left.10 \mathrm{ml}\right]$

- Collect in sample bottle, code and store in freezer e $0.4^{\circ} \mathrm{C}$.

- Bring samples to room temperature (5 per set), cover with foil punctured caps and place in vacuum oven.

- Concentrate samples $\left(\mathrm{CHCl}_{3}\right)$ e $40^{\circ} \mathrm{C}$, vac pressure e $15^{\prime \prime}$ (oven setting 3.5) to a volume of $3 \mathrm{ml}$. [time: $2: 15 \mathrm{hr}$ ]

- Prepare $\mathrm{Na}_{2} \mathrm{SO}_{4}$ columns using rinsed and baked $5 \mathrm{ml}$ disposable pipets and $0.6 \mathrm{gm}^{2} \mathrm{Na}_{2} \mathrm{SO}_{4}$. Vibrate to pack and rinse col. with $3 \mathrm{vol}$. $\mathrm{CHCl}_{3}$ and blow out with $\mathrm{N}_{2}$.

- Pass sample through column with $\mathrm{N}_{2}$ and collect sample and $3,2 \mathrm{ml}$ rinses in $12 \mathrm{ml}$ centrifuge tube, [time: $30 \mathrm{~min}$ ]

- Concentrate sample to $1 \mathrm{ml}$ e $60^{\circ} \mathrm{C}$, vac. pres. $20^{\prime \prime}$ (oven setting e 4) [time: $2 \mathrm{hr}$ ]

- Dilute sample to $5 \mathrm{ml}$ with Hexane and concentrate to $0.5 \mathrm{ml}$.

- Transfer to preweighed $2 \mathrm{ml}$ vials. Rinse and concentrate twice diluting final vol to $1 \mathrm{ml}$.

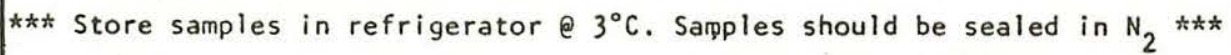

- Determine total hydrocarbons with first injection to GC [inject 2ul]

- Prepare liquid chromatography columns with $175 \mathrm{~mm}$ of $60 / 200$ mesh silica gel. (activated at $285^{\circ} \mathrm{C}$ for $12 \mathrm{hr}$ )

- Wash column with $40 \mathrm{ml}$ hexane and drain to surface.

- Load sample onto column along with 3, $2 \mathrm{ml}$ rinses.

- Drain to surface and elute with $12 \mathrm{ml}$ hexane.

- Discard first $5 \mathrm{ml}$ and collect next $13 \mathrm{ml}$ in original centrifuge tube.

- Concentrate e $60^{\circ} \mathrm{C}$; vacuum $20^{\prime \prime}$ to $0.3 \mathrm{ml}$. [time: $1: 30 \mathrm{hr}$ ]

- Dilute to $5 \mathrm{ml}$ with hexane and determine exact volume by weighing. 
Table 3

WESTINGHOUSE ELECTRIC CORPORATION

BLM - LOBSTER RESEARCH PROGRAM

Hydrocarbon Analyses: GC/ seawater procedures continued

- Label sample with original code and add "A"

- Elute LC column further with $32 \mathrm{mls} 40 / 60$ (vol/vol) benzene- hexane.

- Collect $32 \mathrm{mls}$ in clean, preweighed sample bottle.

- Concentrate e $60^{\circ} \mathrm{C}$ and vacuum pressure $20^{\prime \prime}$ to $0.3 \mathrm{ml}$ [time: $2 \mathrm{hr}$ ]

- Rinse with $5 \mathrm{ml}$ and concentrate to $0.3 \mathrm{ml}$.

- Dilute to $5 \mathrm{mls}$., weigh and determine exact volume.

- Label with original sample code number and add "B"

- Inject both A and B samples to temperature programmed dual flame FID GC.

- Quantitate hydrocarbons and provide qualitative record of aliphatic and aromatic fractions.

- Store samples in $\mathrm{N}_{2}$ in vials refrigerated e $3^{\circ} \mathrm{C}$. 
Figure 1

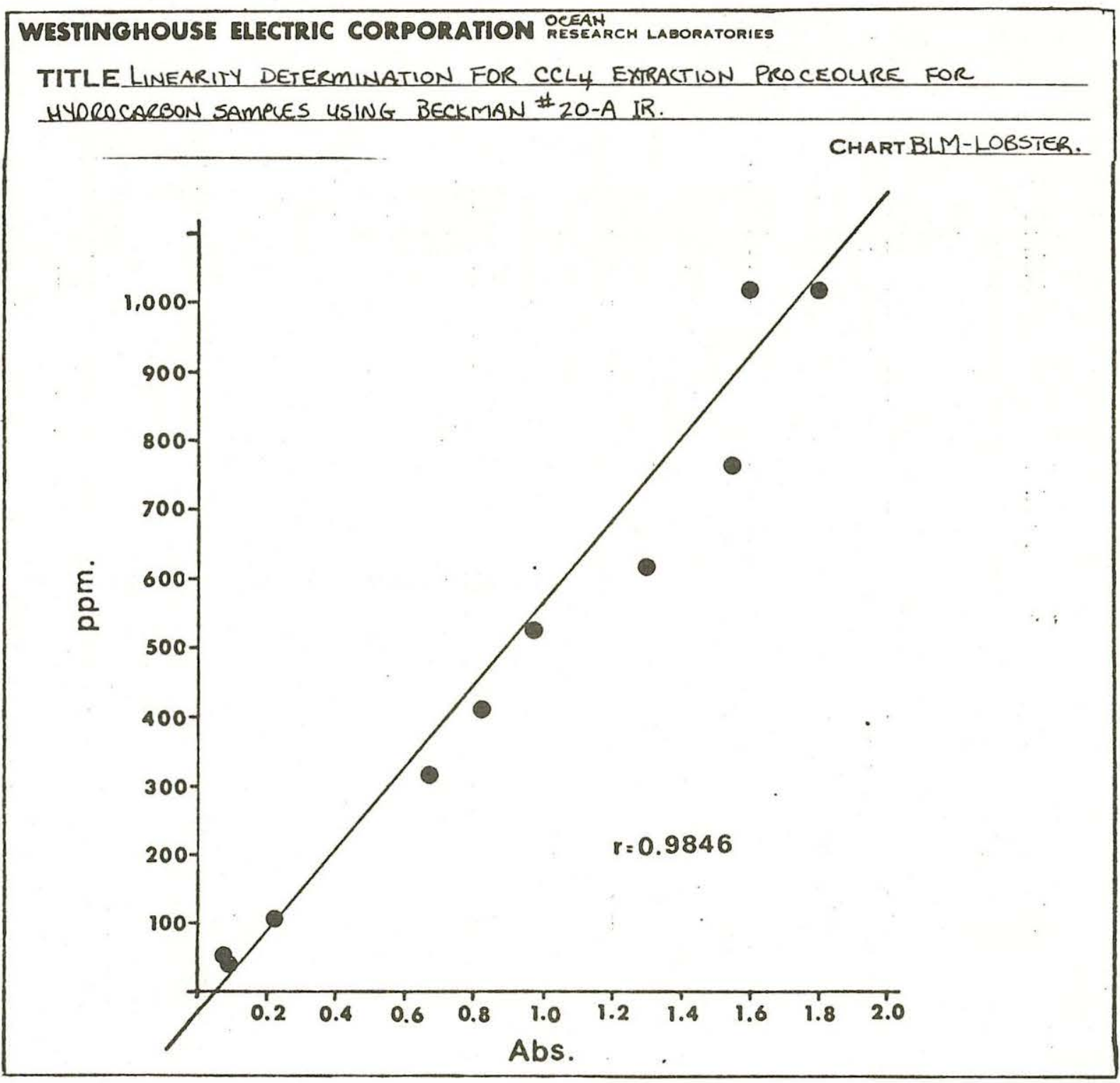


Figure 2

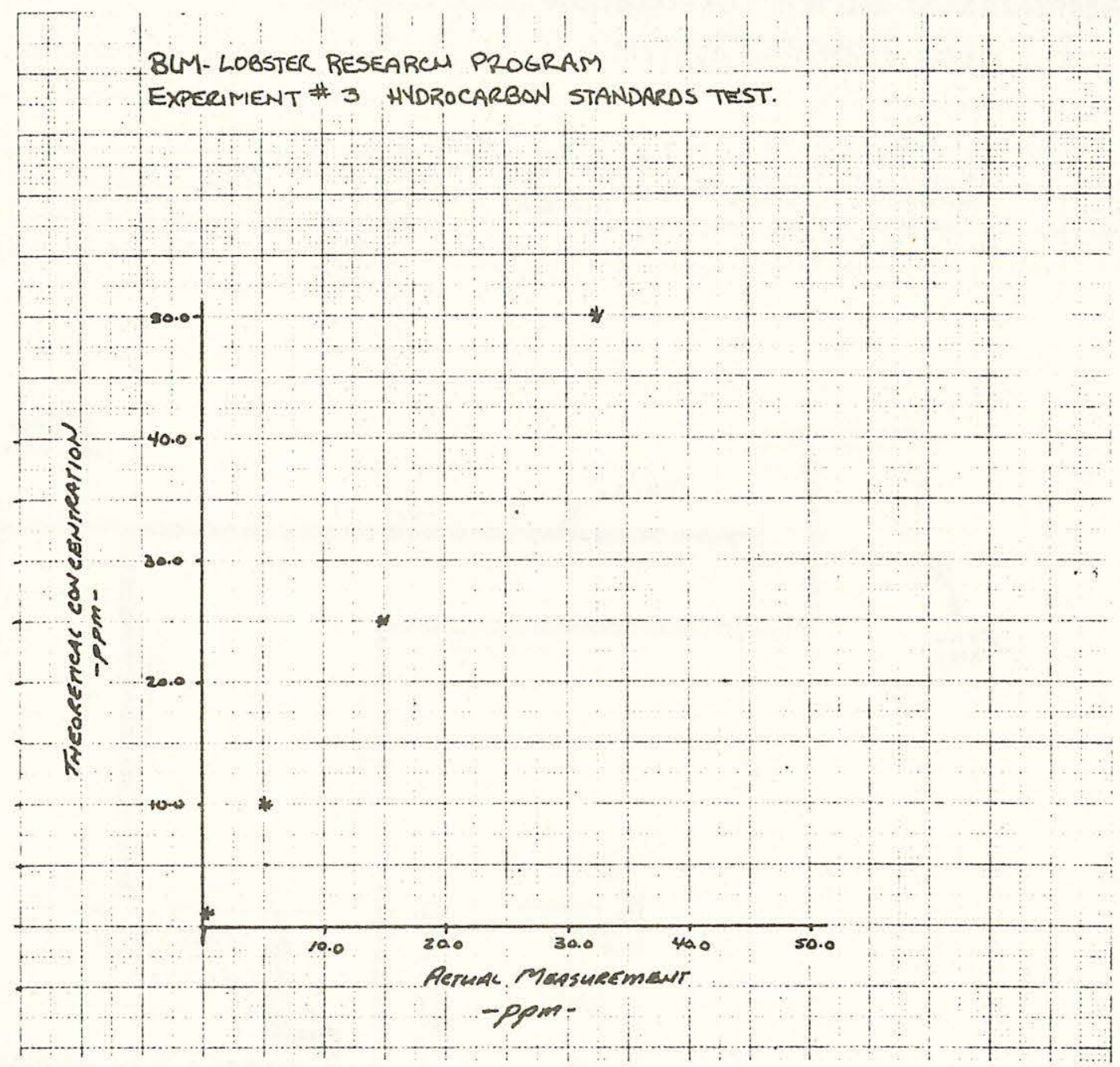


Figure 3

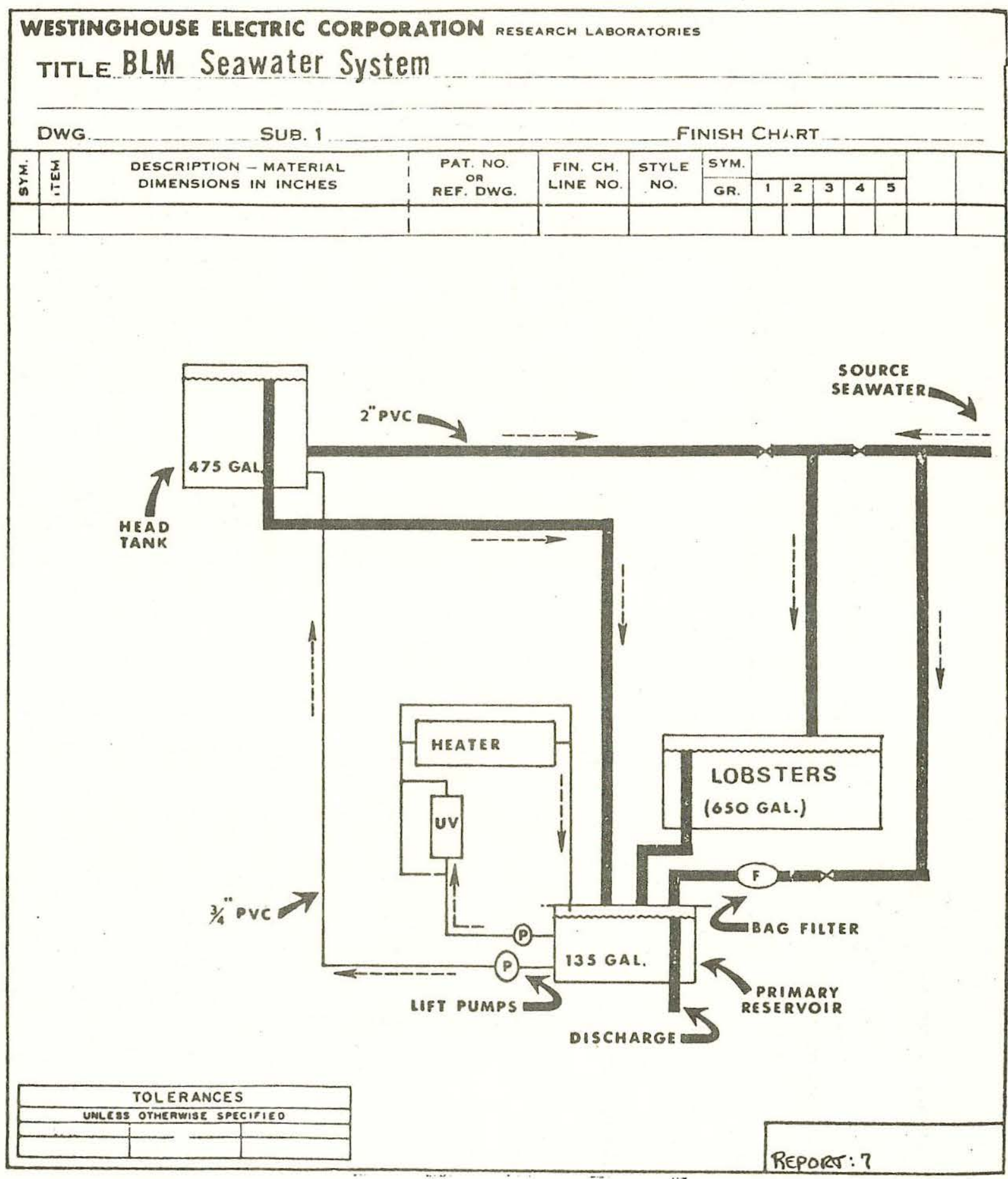


which are within $2^{\prime} \times 4^{\prime} \times 0.5^{\prime}$ reinforced fiberglass aquariums with perforated PVC false bottoms.

Monitoring of the growth and development for each lobster consists of feeding twice daily and measuring the times between molts and the sizes of the cast carapaces. Water quality is monitored daily by measuring ambient and controlled seawater temperatures, dissolved oxygen, salinity and $\mathrm{pH}$.

The diet for the AGRO lobsters consists of mixes of crustacea and molluscs. Included in these diets are random feedings with quarter deck Crepidula fornicata, mussels Mytilus edulis, scallop Argopectin irradians, quahogs Venus mercenaria, brine shrimp Artemia salina, and green crabs Carcinides maenas.

TASK B: BEGG

The egg-lobster oil-exposure tests included experiments with mature eggs from "golden" egg lobsters about to hatch and "black" egg-lobsters which had recently extruded their eggs. For each test 10 offshore lobsters were used; 5 for control and 5 for oil exposure. Theoretical fecundities were determined for each lobster and each egger was observed for one week prior to use. A $3^{\prime} \times 4^{\prime} \times 1.5^{\prime}$ fiberglass flow-through system was set up with 4" of 1" diameter coarse sediments spread across the bottom. Flow rate through the system was adjusted to 5 liters/min. with the seawater entering and exiting 12" below the water surface. After conditioning the system for one week, five test lobsters were placed into the flow-through system and behavior was observed at four-hour intervals for a period of 24 hours. The lobsters were then removed, the entry port was positioned and $456 \mathrm{~m} 1$ of API Reference South Louisiana Crude Oil was spilled on the surface of the flow-through system. After 22 hours of reacting, the water level was lowered so that all the sediments were completely covered with oil. This condition remained for 2 hours after which the water level was again raised to the original level. The five test lobsters were again returned via the circular entry port to the oil-contaminated system. Flow rate was again adjusted., to 5 litres/minute and the lobsters' behavior was recorded every four hours 
for a 24 hour period. After 24 hours of exposure to water soluble fractions of surface spilled oil and oil-contaminated sediments, the lobsters were removed through the entry port, rinsed with fresh seawater and returned to their individual genetic tanks to await egg development.

Throughout each experiment 30 seawater samples were extracted for hydrocarbon documentation. Fifteen samples were extracted with $\mathrm{CCl}_{4}$ for IR analysis and 15 were acidified to $\mathrm{pH} 2$ and extracted with $\mathrm{CHCl}_{3}$ for GC analysis.

As each test egg-lobster hatched its eggs, the numbers of successful first-stage larvae, dead larvae and unhatched eggs were recorded. Also, the time for total hatch was determined, as well as the success of a representative number of fry through their fourth larval stage.

TASK C: CTOX

Only the flow-through assay tests using mass cultures of lobster larvae were completed by Westinghouse between June 1977 and July 1978. The procedure for conducting the flow-through assay consisted on counting out 1000 24-hour first-stage fry per test concentration from a single egg lobster. In the first of four assays, whole fraction API reference South Louisiana Crude $0 i 1$ was used at concentrations of 0.1 and $1.0 \mathrm{ppm}$ (vol./vol.) in seawater and water soluble fractions (WSF) of the same oil at concentrations of 10 and 50ppm (oil in seawater). The oil-exposure procedure consisted of making oil emulsions for the 0.1 and 1.0 concentrations at $10^{3}$ every four hours to reduce weathering and extreme volatilization. These emulsions were peristaltically pumped through a teflon and glass system to a $51 / \mathrm{min}$. flowthrough culture tank housing the larvae (Forns, 1977). The water soluble fractions were made 24 hours in advance and allowed to stir gently in 3.5 gal. glass carboys. The surface layer of crude oil was allowed to remain and only the WSF below was delivered to the larval tanks. The second, third and fourth tests were done with oil emulsions of $0.1,0.5,1.0$ and $1.5 \mathrm{ppm}$ crude oil in seawater.

During each assay flow rates, feeding and new oil emulsions were maintained every four hours for the entire time of larval development 
(approximately 17 days). Hydrocarbon extractions were made for each test concentration every 48 hours and each oil concentration tank was dropped, cleaned and larvae staged and counted every third day of the test. Records were kept of the volumes of oil used in each test system, amount of food used, and growth and development time to fourth stage and survival of larvae throughout the test. 
RESULTS

Between March 1977 and July 1978, 32 experiments were undertaken by Westinghouse on Tasks A1, B1, B2 and C1, C2c and C2d. Sixty-nine series of histological preparations were made for first through fourth stage larvae (CTOX) and 43 tissue sections from the diseased AGRO task were prepared. One hundred and sixty-four hydrocarbon analyses of seawater were performed from the BEGG and CTOX experiments. A summarization of the project status is given in Table 4. Results of the work accomplished on the individual tasks is as follows.

TASK A: AGRO

Temperature data from the flow-through seawater system is given in Table 5. During the time from March 1977 through July 1978, the lowest temperature maintained in the AGRO system was $13.2^{\circ} \mathrm{C}$ when the lobsters were acclimating to ambient waters in May 1978. Survival of the AGRO 1obsters is shown in Figure 4 and summarized in Table 6 . From this data it appears that all of the different grow-out lobsters were affected by the bacteria problem in early fall of 1977. Also, the larvae which were exposed to $1.0 \mathrm{ppm}$ show the greatest survival. While this cannot be considered statistically significant because of the mortalities by the disease, the $1.0 \mathrm{ppm}$ lobsters had a $15 \%$ higher survival record.

TASK B: BEGG

Results from the "golden" egger tests in June 1977 indicate a 7\% difference in hatch success between control and oil-exposed eggers. Sixtyfive percent of the controls and $58 \%$ of the fry from the oiled eggers successfully hatched. The percentage of unhatched eggs was $0.9 \%$ for controls and 1.4 for oiled eggers. The survival record to fourth stage for this test did not indicate any difference between controls or oil-exposed lobsters. However, there was a noticeable difference in the post-fourth stage survival 


\section{BLM-LOBSTER RESEARCH RROGRAM}

CONTRACT STATUS AS OF JULY, 1978

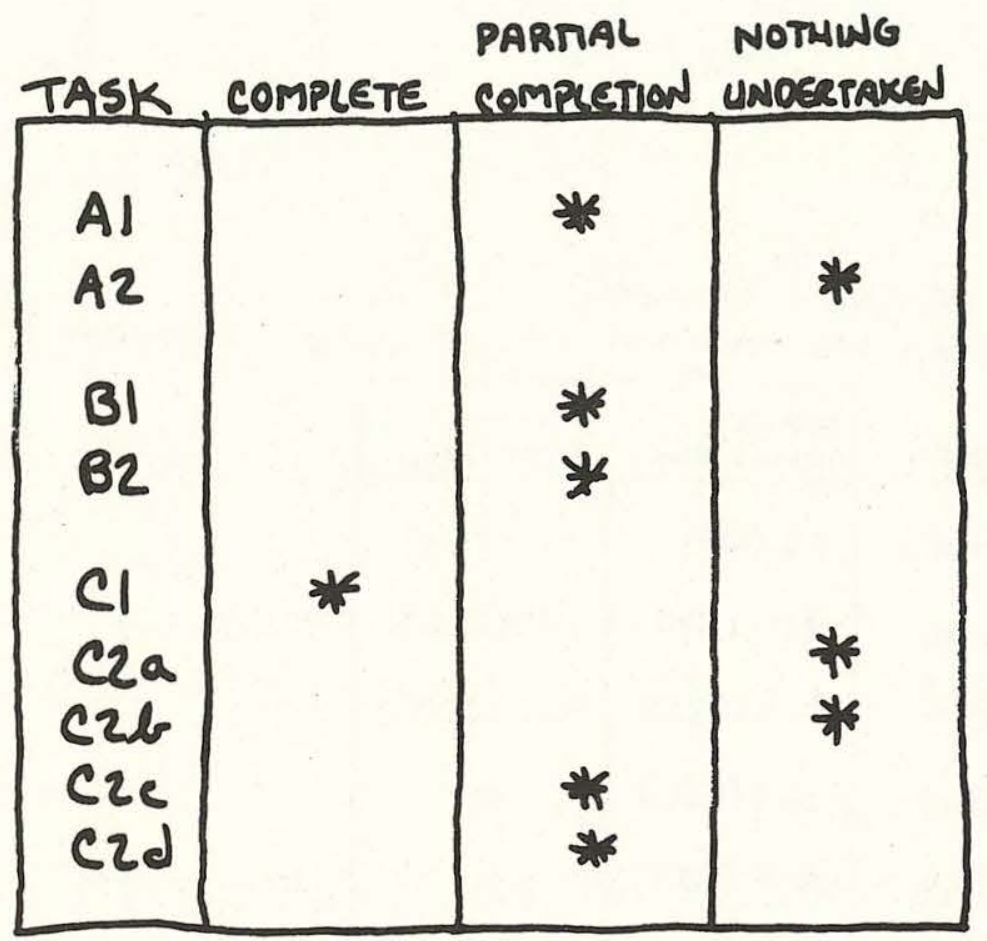


Table 5

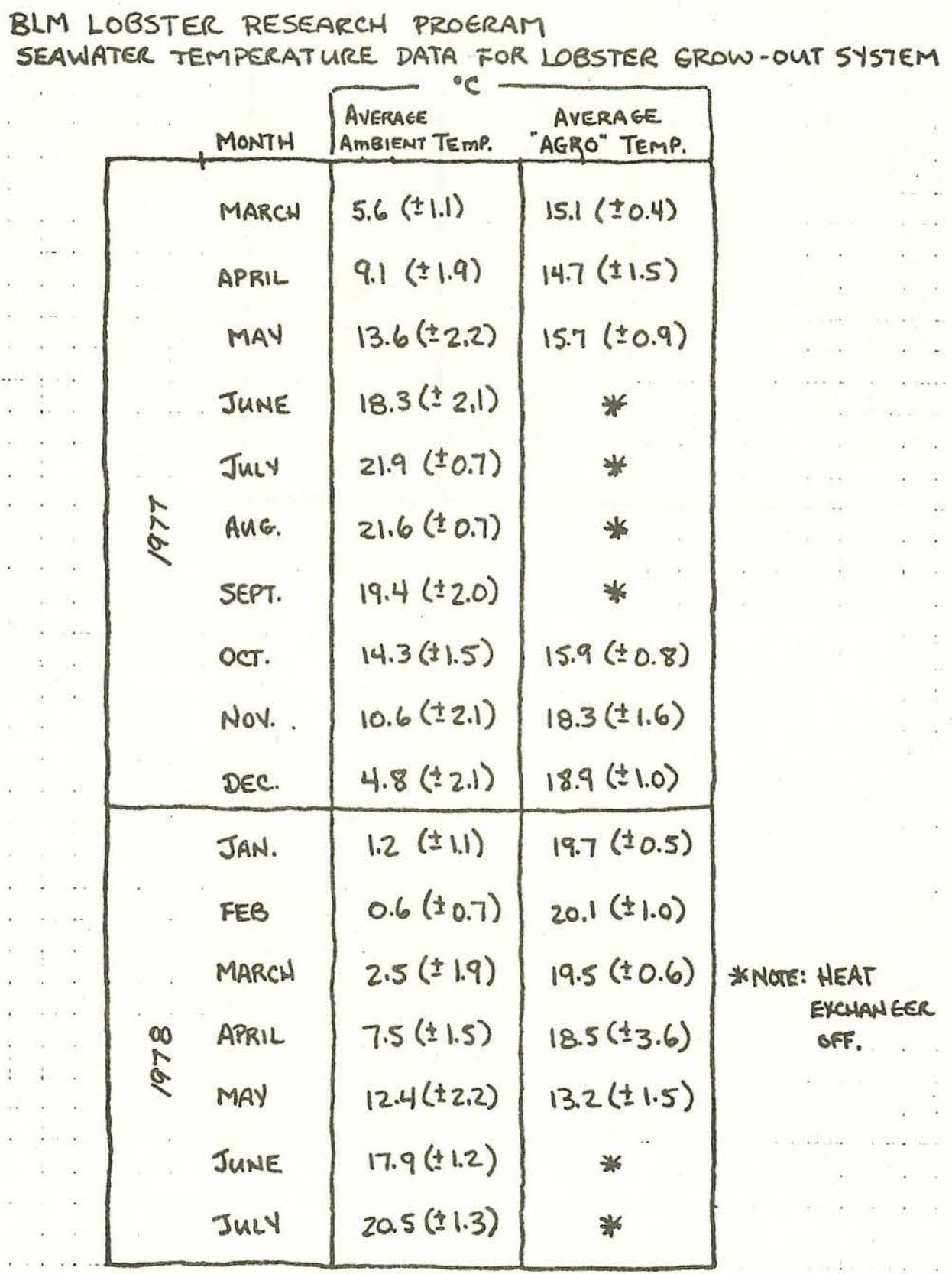


Figure 4. Survival Record for Original 1976 Year Class

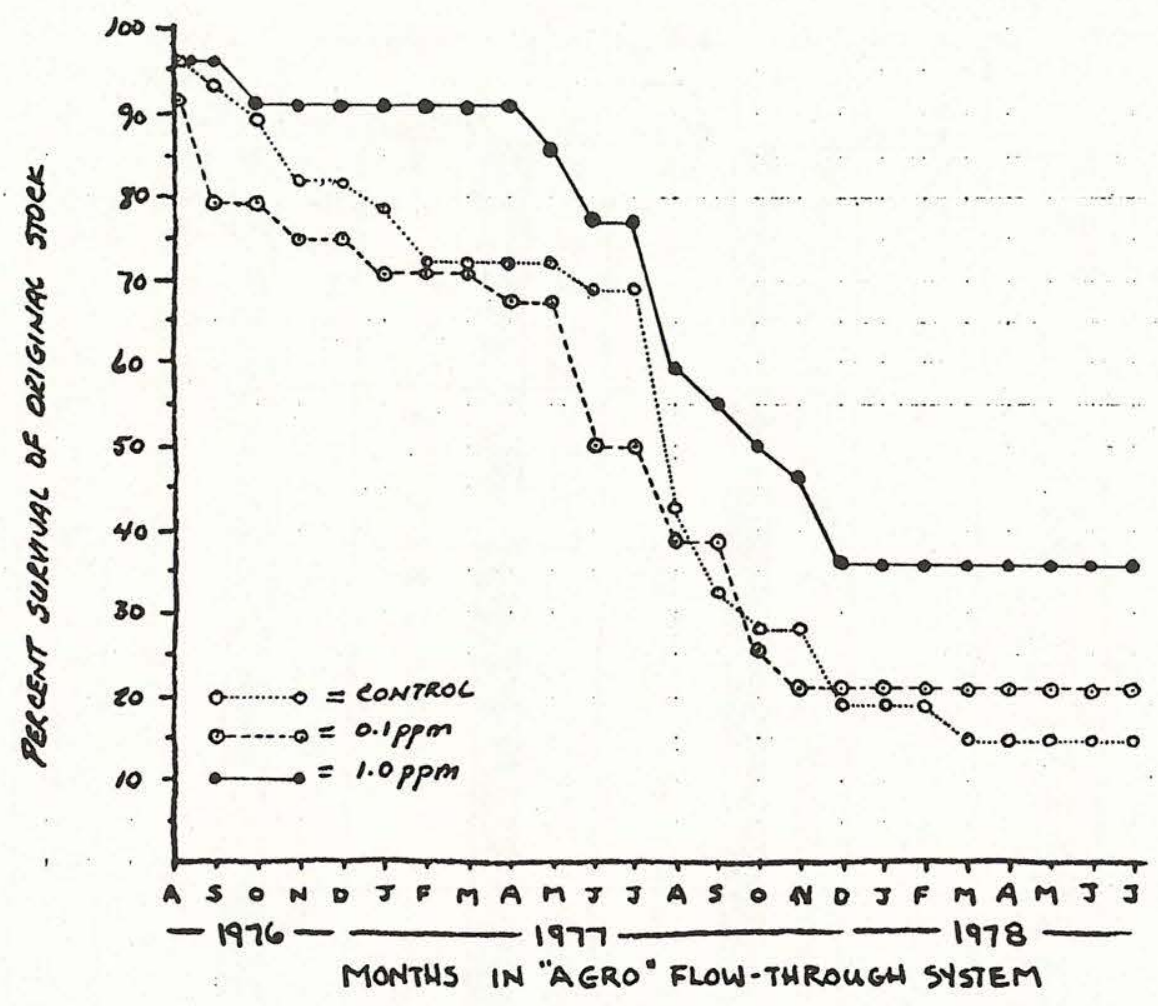


Table 6. Survival Record for Original 1976 Year Class

\begin{tabular}{|c|c|c|c|c|c|c|c|c|c|c|c|c|}
\hline & MONTH & CON & $\%$ & & $\begin{array}{l}-0.1 p \\
\text { SWRVIVI }\end{array}$ & . & & $\begin{array}{l}-1.0 \mathrm{p} \\
* \\
\text { Survivil }\end{array}$ & & & $\begin{array}{l}\text { TOTA } \\
176 \mathrm{VR} \\
\text { sugvivi }\end{array}$ & $\begin{array}{l}\text { CLASS } \\
\%\end{array}$ \\
\hline & $\begin{array}{l}\text { JULY } \\
\text { AUG. } \\
\text { SEPT. } \\
\text { OCT. } \\
\text { NOV. } \\
\text { DEC. }\end{array}$ & $\begin{array}{l}54 \\
52 \\
50 \\
48 \\
44 \\
44 \\
\end{array}$ & $\begin{array}{l}100 \\
96 \\
93 \\
89 \\
82 \\
82 \\
\end{array}$ & | & $\begin{array}{l}24 \\
22 \\
19 \\
19 \\
18 \\
18 \\
\end{array}$ & $\begin{array}{l}100 \\
92 \\
79 \\
79 \\
75 \\
75 \\
\end{array}$ & 列 & $\begin{array}{l}22 \\
21 \\
21 \\
20 \\
20 \\
20\end{array}$ & $\begin{array}{l}100 \\
96 \\
96 \\
91 \\
91 \\
91\end{array}$ & 桨 & $\begin{array}{l}100 \\
95 \\
90 \\
87 \\
82 \\
82 \\
\end{array}$ & $\begin{array}{l}100 \\
95 \\
90 \\
87 \\
82 \\
82\end{array}$ \\
\hline & $\begin{array}{l}\text { JAN. } \\
\text { FEB } \\
\text { MAR. } \\
\text { APRIC } \\
\text { MAV } \\
\text { JUNE } \\
\text { JULY } \\
\text { AUE. } \\
\text { SEPT. } \\
\text { OCT. } \\
\text { NOV. } \\
\text { DES. }\end{array}$ & $\begin{array}{l}42 \\
39 \\
39 \\
39 \\
39 \\
37 \\
37 \\
23 \\
17 \\
15 \\
15 \\
10\end{array}$ & $\begin{array}{l}78 \\
72 \\
72 \\
72 \\
72 \\
69 \\
69 \\
43 \\
32 \\
28 \\
28 \\
19\end{array}$ & 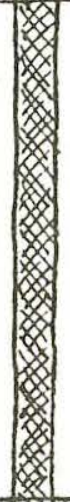 & $\begin{array}{l}17 \\
17 \\
17 \\
16 \\
16 \\
12 \\
12 \\
9 \\
9 \\
6 \\
5 \\
5\end{array}$ & $\begin{array}{l}71 \\
71 \\
71 \\
67 \\
67 \\
50 \\
50 \\
38 \\
38 \\
25 \\
21 \\
21\end{array}$ & : & $\begin{array}{l}20 \\
20 \\
20 \\
20 \\
19 \\
17 \\
17 \\
13 \\
12\end{array}$ & $\begin{array}{l}91 \\
91 \\
91 \\
91 \\
86 \\
77 \\
77 \\
59 \\
55 \\
50 \\
46 \\
36\end{array}$ & 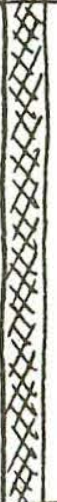 & $\begin{array}{l}79 \\
76 \\
76 \\
75 \\
74 \\
66 \\
66 \\
45 \\
38 \\
32 \\
30 \\
23\end{array}$ & $\begin{array}{l}79 \\
76 \\
76 \\
75 \\
74 \\
66 \\
66 \\
45 \\
38 \\
32 \\
30 \\
23\end{array}$ \\
\hline & $\begin{array}{l}\text { JAN. } \\
\text { FEB. } \\
\text { MAR. } \\
\text { APRIL } \\
\text { MAY } \\
\text { JUNE } \\
\text { JULY }\end{array}$ & $\begin{array}{l}10 \\
10 \\
8 \\
8 \\
8 \\
8 \\
8\end{array}$ & $\begin{array}{l}19 \\
19 \\
15 \\
15 \\
15 \\
15 \\
15\end{array}$ & : & $\begin{array}{l}5 \\
5 \\
5 \\
5 \\
5\end{array}$ & $\begin{array}{l}21 \\
21 \\
21 \\
21 \\
21 \\
21 \\
21\end{array}$ & : & $\begin{array}{l}8 \\
8 \\
8 \\
8 \\
8 \\
8 \\
8\end{array}$ & $\begin{array}{l}36 \\
36 \\
36 \\
36 \\
36 \\
36 \\
36\end{array}$ & 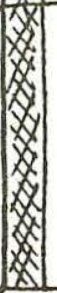 & $\begin{array}{l}23 \\
23 \\
21 \\
21 \\
21 \\
21 \\
21 \\
\end{array}$ & $\begin{array}{l}23 \\
23 \\
21 \\
21 \\
21 \\
21 \\
21\end{array}$ \\
\hline
\end{tabular}


of fry from control and oiled lobsters. Fifty percent of the controls grew beyond the eighth larval stage, whereas less than $20 \%$ of the larvae from oiled eggers survived beyond the eighth molt. Results from the "black" egg lobster tests conducted from November 1977 through March 1978 showed an 18\% lower hatch success by the oil-exposed eggers. Table 7 shows the consolidation of the hatch success for control and oiled egg lobsters. Although egg development times for both controls and oil-exposed lobsters were similar the actual hatch period was substantially longer for the oil-exposed egg lobsters. Apparently, the oiled lobsters had greater difficulty in successfully releasing their fry. Also, the number of unhatched eggs by oiled eggers was more than $30 \%$ higher than for controls.

TASK C: CTOX

Four flow-through toxicity tests were accomplished during the natural hatching periods in 1977 and 1978. From the results of these flow-through oil assays we observed a significant mortality to developing larvae in the WSF fraction of the 10 and $50 \mathrm{ppm}$ oil in seawater tests. From the results of the three oil emulsion tests with whole fraction oil in seawater there appears to be a significant mortality threshold for lobster larvae between the 0.5 and $1.0 \mathrm{ppm}$ oil concentrations. The times for larval development are consistently longer for oil-exposed larvae and the average sizes for larvae exposed to $1.0 \mathrm{ppm}$ oil concentration were $25 \%$ smaller than for the lower oil concentrations tested. 
WESTINGHOUSE ELECTRIC CORPORATION

BLM-LOBSTER RESEARCM PROGRAM

BEGE-2 FIRST BCACKEGEER TEST

\begin{tabular}{|c|c|c|c|c|}
\hline \multicolumn{5}{|c|}{ CONTROC LOBSTERS } \\
\hline $\begin{array}{l}\text { EG ER } \\
\text { II }\end{array}$ & $\begin{array}{l}\text { CARAPACE } \\
\text { SIZE }\end{array}$ & $\begin{array}{l}\text { THEORETICAL } \\
\text { TECUNOITY }\end{array}$ & $\begin{array}{l}\text { ACTUAL } \\
\text { FECUNDIBY }\end{array}$ & $\begin{array}{c}\% \\
\text { Suceess }\end{array}$ \\
\hline$I$ & 90.6 & 9,990 & 10,119 & 101.3 \\
\hline III & 81.8 & 7,455 & 99 & 1.3 \\
\hline JII & 107.0 & 16,090 & 6,211 & 38.6 \\
\hline IV & 115.4 & 19,980 & 17,078 & 85.5 \\
\hline$\pi z$ & 84.2 & 8,990 & 5,097 & 56.7 \\
\hline \multicolumn{5}{|c|}{ OIL-EXPOSED LOBSTERS } \\
\hline I & 90.3 & 10,618 & 8.113 & 80.9 \\
\hline$\pi$ & 80.2 & 7.132 & 2,690 & 327 \\
\hline III & ४३.1 & 10,933 & 5.276 & 48.3 \\
\hline II & 1033 & 14,726 & 5,669 & 38.5 \\
\hline$\pi$ & 111.4 & 18,281 & 413 & 2.3 \\
\hline
\end{tabular}


REFERENCES

Corner, E.D., A.J. Southward and E.C. Southward, 1968. Toxicity of oil spil1 removers ("detergents") to marine life: an assessment using the intertidal barnacle Elminius modestus. Jour. Mar. Biol. Ass. U.K., $48(1): 29-47$.

Forns, J.M., 1976. Initial evaluations of larval lobster Homarus americanus) exposure to South Louisiana Crude 0il. API report CEA-24.

Herrick, F.H., 1896. The American Lobster: A Study of Its Habits and Developments. Bull. US Fish Comm., 15:1-252.

Hughes, J.T. and G.C. Matthiesses, 1962. Observations on the Biology of the American Lobster Homarus americanus. Limnol. \& Oceano. 7:414-421.

Kash, D.E. et.a1., 1973. Energy Under the Oceans, Oklahoma University Press.: 269-283

Ketchum, B., 1974. Outer Continental Shelf $0 i 1$ and Gas Development. Joint committee hearings of the United States Senate, p. 34

Kuhnhold, W.W., 1973. The influence of crude oils on fish fry. In Marine Pollution and Sea Life, Fishing News Books Ltd., London; 315-317.

Mironov, O.G., 1973. Effect of oil pollution on flora and fauna of the Black Sea. In Marine pollution and Sea Life, Fishing News Books Ltd., London, 222-234.

National Academy of Sciences, 1975. Pollution in the Marine Environment, p. 6.

Portmann, J.E., 1973. Results of acute toxicity tests with marine organisms, using a standard method. In Marine pollution and Sea Life, Fishing News Books Ltd.; 214.

Smith, J.E., 1968. Torrey Canyon Pollution and Marine Life. Cambridge University Press; 117-120.

Wel1s, P.G., and J.B. Sprague, 1976. Effects of crude oil on lobster larvae in the laboratory. J. Fish. Res. Bd. Canada, 33:7, p. 1604 


\begin{tabular}{|c|c|c|}
\hline $\begin{array}{l}\text { REPORT DOCUMENTATION } \\
\text { PAGE }\end{array}$ & \begin{tabular}{|l|l|} 
1. REPORT NO. & 2. \\
WHOI $-81-75$ & \\
\end{tabular} & 3. Recipient's Accession No. \\
\hline \multirow{2}{*}{\multicolumn{2}{|c|}{$\begin{array}{l}\text { 4. ritle and subtitle } \\
\text { CRUDE OIL EFFECTS TO DEVELOPMENTAL STAGES OF THE AMERICAN } \\
\text { LOBSTER }\end{array}$}} & $\begin{array}{l}\text { 5. Report Date } \\
\text { September } 1981\end{array}$ \\
\hline & & 6. \\
\hline \multicolumn{2}{|c|}{$\begin{array}{l}\text { 7. Author(s) } \\
\text { Judith M. Capuzzo }\end{array}$} & 8. Performing Organization Rept. No. \\
\hline \multicolumn{2}{|c|}{$\begin{array}{l}\text { 9. Performing Organization Name and Address } \\
\text { Woods Hole Oceanographic Institution } \\
\text { Woods Hole, Massachusetts } 02543\end{array}$} & $\begin{array}{l}\text { 10. Project/Task/Work Unit No. } \\
\text { 11. Contract(C) or Grant(G) No. } \\
\text { (C) AA551-CT9-5 } \\
\text { (G) }\end{array}$ \\
\hline \multicolumn{2}{|c|}{$\begin{array}{l}\text { 12. Sponsoring Organization Name and Address } \\
\text { U.S. Department of Interior, Bureau of Land Management }\end{array}$} & $\begin{array}{l}\text { 13. Type of Report \& Period Covered } \\
\text { 14. Technical }\end{array}$ \\
\hline
\end{tabular}

15. Supplementary Notes

This report should be cited as: Woods Hole Oceanog. Inst. Tech. Rept. WHOI-81-75.

16. Abstract (Limit: 200 words)

The physiological effects of South Louisiana crude oil on larvae and juveniles of the American lobster Homarus americanus have been investigated in continuous flow bioassay systems. Disruption in the energetics of larval development has been observed and correlated with a shift in the normal patterns of lipid utilization and storage in larval lobsters. Hydrocarbon turnover appears to be rapid and little accumulation, except of the higher molecular weight constituents, is observed. Recovery of larval and early postlarval stages is not immediate upon transfer to uncontaminated seawater and the normal pattern of energy storage and utilization is only slowly restored.

Postlarval lobsters are less sensitive to crude oil-seawater mixtures than the larval stages and no disruption in energetics has been observed. Reductions in respiratory activity and bioaccumulation of both aliphatic and aromatic compounds, however, have been observed in postlarval lobsters exposed to.0il contaminated sediments. This suggests that postlarval lobsters have longer retention times and slower turnover rates of petroleum hydrocarbons than the larval stages and persistence of petroleum hydrocarbons in sediments may present a chronic contamination problem to benthic stages of the American lobster.

17. Document Analysis a. Descriptors

1. 0 i1

2. Lobsters

3. Energetics

b. Identifiers/Open-Ended Terms

19. Security Class (This Report)

20. Security Class (This Page)
21. No. of Pages 102

22. Price 


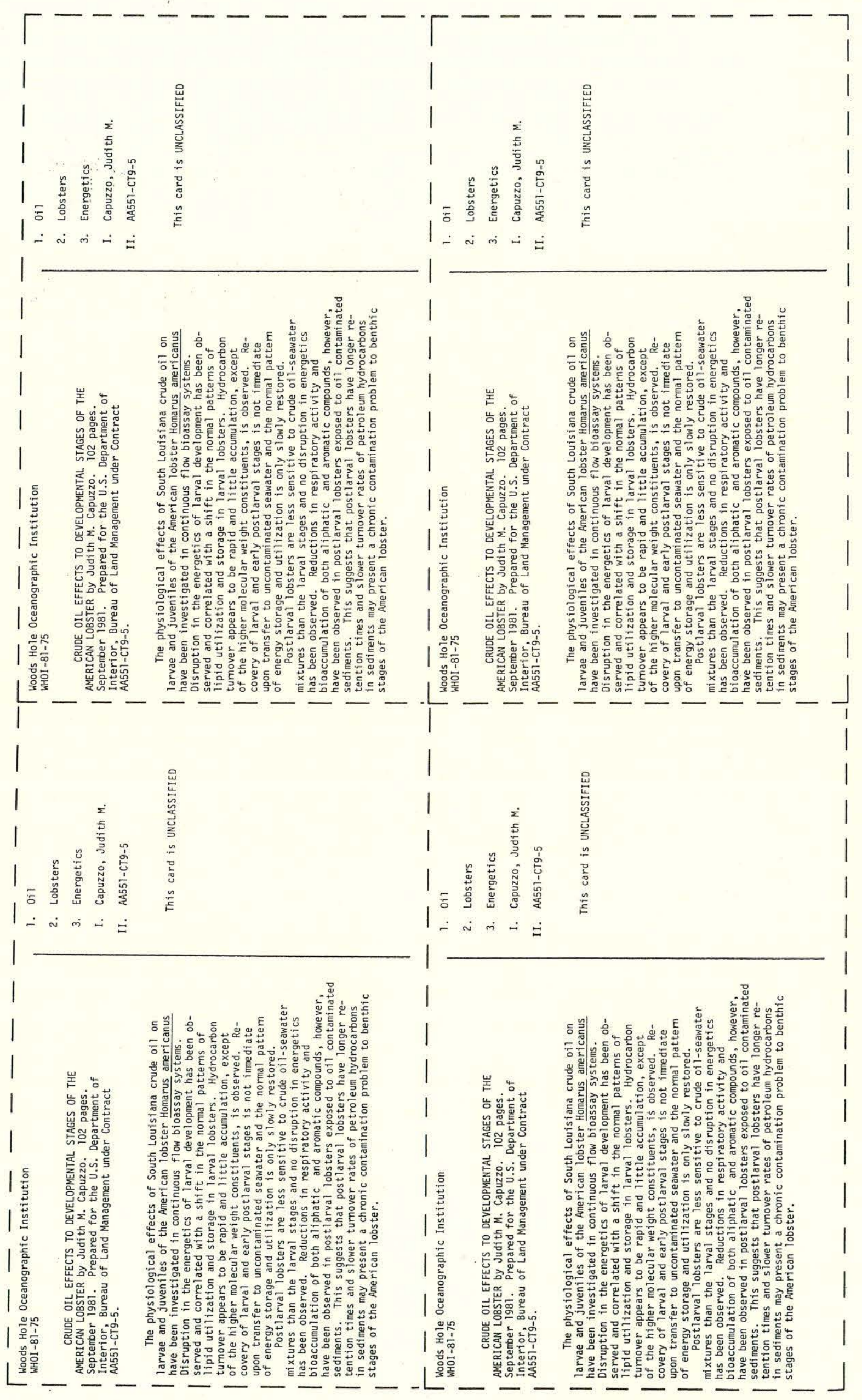

